\title{
ESTUDO IN VITRO DO POTENCIAL CARIOSTÁTICO DOS SELANTES \\ RESINOSOS, DOS CIMENTOS IONOMÉRICOS, DO DIAMINO FLUORETO DE \\ PRATA E DO VERNIZ FLUORETADO APLICADOS EM SUPERFÍCIE OCLUSAL \\ DE MOLARES PERMANENTES HUMANOS
}

THEREZA CHRISTINA LOPES COUTINHO

Tese apresentada à Faculdade de Odontologia de Bauru, da Universidade de São Paulo, como parte dos requisitos para obtenção do título de Doutor em Odontologia, área de Odontopediatria.

(Edição Revisada)

Orientadora: Profa $\mathrm{Dr}^{a}$ Maria Francisca Thereza Borro Bijella 


\section{ESTUDO IN VITRO DO POTENCIAL CARIOSTÁTICO DOS SELANTES \\ RESINOSOS, DOS CIMENTOS IONOMÉRICOS, DO DIAMINO FLUORETO DE \\ PRATA E DO VERNIZ FLUORETADO APLICADOS EM SUPERFÍCIE OCLUSAL \\ DE MOLARES PERMANENTES HUMANOS}

THEREZA CHRISTINA LOPES COUTINHO

Tese apresentada à Faculdade de Odontologia de Bauru, da Universidade de São Paulo, como parte dos requisitos para obtenção do título de

Doutor em Odontologia, área de Odontopediatria.

(Edição Revisada)

BAURU

2002 


\section{Coutinho, Thereza Christina Lopes}

C837e Estudo in vitro do potencial cariostático dos selantes resinosos, dos cimentos ionoméricos, do diamino fluoreto de prata e do verniz fluoretado aplicados em superfície oclusal de molares permanentes humanos. 116 p. : il.; $30 \mathrm{~cm}$.

Tese. (Doutorado) - Faculdade de Odontologia de Bauru - USP.

Orientadora: Prof ${ }^{a}$ Dr $^{a}$ Maria Francisca Thereza Borro Bijella.

Autorizo, exclusivamente para fins acadêmicos e científicos, a reprodução parcial ou total desta tese, por processos fotocopiadores e outros meios eletrônicos.

Assinatura da autora:

Data: $28 / 08 / 2002$

A metodologia empregada nesta Tese foi submetida ao Comitê de Ética em Pesquisa da Faculdade de Odontologia de Bauru - USP, que a aprovou em reunião no dia 27 de maio de 1999, considerando não existir questões éticas como apresentado no ANEXO C. 


\section{PROFa . THEREZA CHRISTINA LOPES COUTINHO}

Filiação

06 de junho de 1965

$1983-1986$

1989

$1990-1992$

$1998-2002$
Ary Sant'Anna Coutinho

Regina Coeli Lopes Coutinho

Niterói - RJ.

Nascimento

Curso de Graduação em Odontologia pela Faculdade de Odontologia da Universidade Federal do Rio de Janeiro - UFRJ

Curso de Especialização em Odontopediatria pela Faculdade de Odontologia da UFRJ

Curso de Pós-Graduação em Odontopediatria, ao nível de Mestrado, na Faculdade de Odontologia da UFRJ

Curso de Pós-Graduação em Odontopediatria, ao nível de Doutorado, na Faculdade de Odontologia de Bauru - USP

Professora Assistente nível I da Disciplina de Odontopediatria da Faculdade de Odontologia da Universidade Federal Fluminense UFF 
Professora Assistente nível II da Disciplina de Odontopediatria da Faculdade de Odontologia da Universidade Federal Fluminense UFF

Associações

ABO - Associação Brasileira de Odontologia - Secção do Rio de Janeiro

ABOPREV - Associação Brasileira de Odontologia de Promoção de Saúde

GRUPO - Grupo Brasileiro de Professores de Ortodontia e Odontopediatria

IADR - International Association for Dental Research

SBPqO - Sociedade Brasileira de Pesquisas Odontológicas 
"É muito importante que o homem tenha ideais. No entanto, é irrelevante alcançá-los ou não. É apenas necessário mantê-los vivos e procurar atingi-los.”

(Dalai Lama) 
Dedico este trabalho

Aos meus pais, Regina Coeli e Ary, àminha avó Nahyr (In memorian), pelo apoio, amor, dedicação e estímulo dispensados em todos os momentos da minha vida. 


\section{AGRADECIMENTOS}

À Deus, meu Pai de todos os momentos, que me carregou no colo e não me deixou esmorecer. A fé no Seu poder preenche cada vez mais a minha alma e o meu coração.

À Prof $^{a}$. Dr ${ }^{a}$ Maria Francisca Thereza Borro Bijella pela grande consideração, orientação segura e inestimável ajuda para a realização desta pesquisa.

Aos professores da Disciplina de Odontopediatria da Faculdade de Odontologia de Bauru: Maria Aparecida de Andrade Moreira Machado, Salete Moura Bonifácio da Silva, José Eduardo Lima, Ruy César Camargo Abdo, Bernardo Gonzalez Vono e Aymar Pavarini, o reconhecimento pela amizade e valiosos ensinamentos transmitidos, que se tornaram importantes para o meu aprimoramento como professora e pesquisadora.

Aos professores das disciplinas da área conexa que contribuíram para a minha formação como Doutora em Odontologia.

Aos colegas do Curso de Doutorado: Edmer, Fabiana, Maria Lígia, Sara e Veridiana, que me mostraram que compartilhar ainda é o melhor caminho para viver em conjunto.

Aos funcionários da Clínica de Odontopediatria: Estela, Fátima, Lia, Lílian e Wilma pela atenção e carinho dispensados.

À querida e grande amiga Dra árcia Cançado Figueiredo, minha gratidão pela valiosa amizade e pelo constante incentivo para que este sonho se tornasse possível.

Às minhas ex-alunas $\mathrm{Dr}^{\mathrm{a}}$. Cintia Carneiro Pinheiro e $\mathrm{Dr}^{\mathrm{a}}$. Raphaela Iscandar Vilela de Abreu pela inestimável ajuda na parte prática deste trabalho.

Ao Prof. Dr. Porphirio José Soares Filho do Departamento de Patologia do Hospital Universitário Antônio Pedro da Universidade Federal Fluminense, pela realização das fotografias e pela orientação na análise ao Microscópio de Luz Polarizada.

À CAPES/MEC pelo suporte financeiro concedido sob a forma de bolsa de estudo.

À Faculdade de Odontologia de Bauru da Universidade de São Paulo o meu agradecimento especial e o reconhecimento pelos ensinamentos transmitidos através de seu corpo docente de alto nível técnico e científico, que contribuíram de maneira ímpar para a minha formação acadêmica. 
À Diretora da Faculdade de Odontologia de Bauru, Prof ${ }^{a}$ Drª Maria Fidela de Lima Navarro e à Comissão de Pós-Graduação da Faculdade de Odontologia de Bauru na pessoa de seu Presidente, Prof. Dr. José Carlos Pereira, meus eternos agradecimentos.

À Prof ${ }^{a}$ Carmen Lúcia Lopes de Sá Pacheco, pela revisão do texto.

A todos os funcionários da biblioteca desta Faculdade, pela revisão das referências bibliográficas.

Aos funcionários da Pós-Graduação pela atenção dispensada, sempre dedicados e prestativos.

A todos que, direta ou indiretamente, contribuíram para a realização desta pesquisa. 


\section{SUMÁRIO}

LISTA DE ILUSTRAÇÕES

$\mathrm{xi}$

LISTA DE ABREVIATURAS, SIGLAS E SÍMBOLOS .................................. xiii

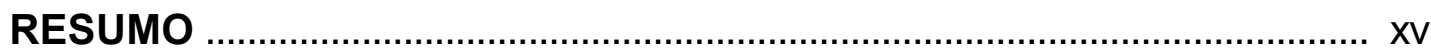

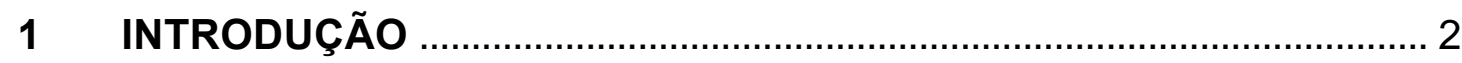

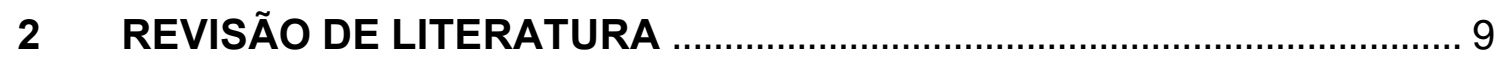

2.1 SELANTES RESINOSOS COM E SEM FLÚOR ….................................... 9

2.2 CIMENTOS DE IONÔMERO DE VIDRO (CIV) PARA SELAMENTO DE

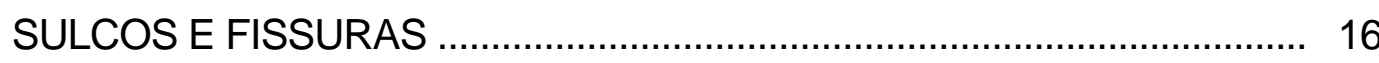

2.3 SOLUÇÃO DE DIAMINO FLUORETO DE PRATA (DFP) .......................... 24

2.4 VERNIZES FLUORETADOS ............................................................... 30

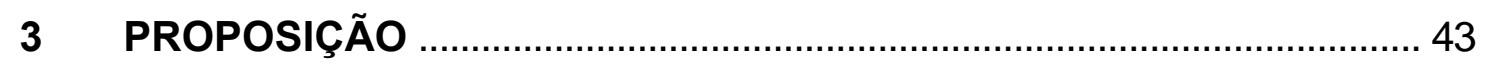

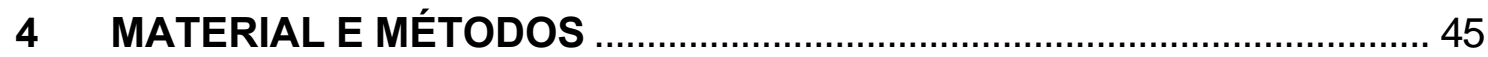

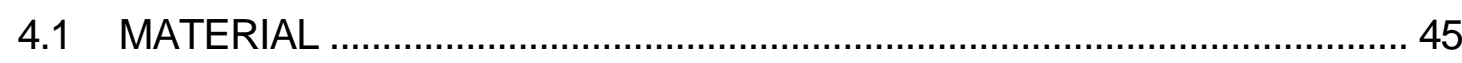

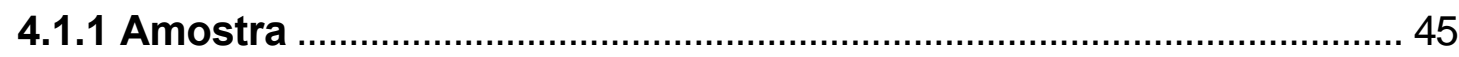

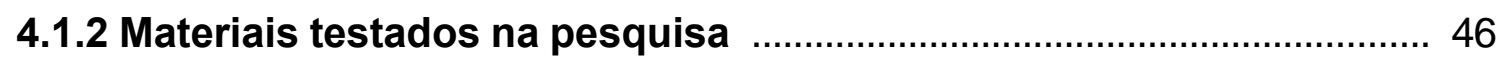

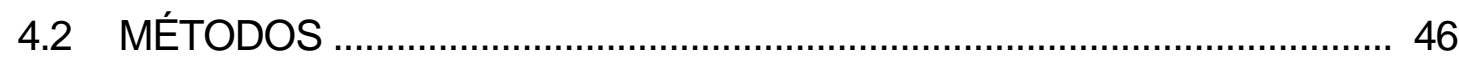

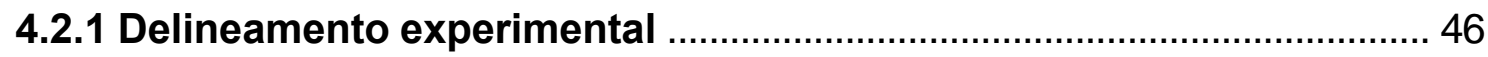

4.2.2 Determinação dos grupos experimentais ......................................... 47

4.2.3 Tratamento da superfície do esmalte ............................................ 48

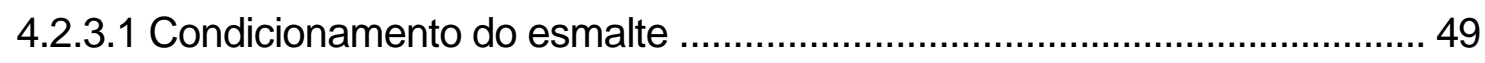

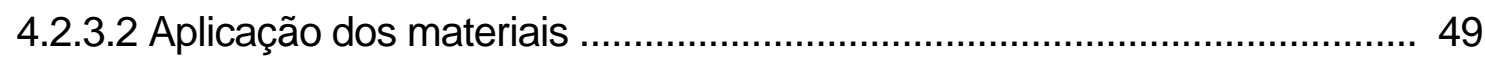

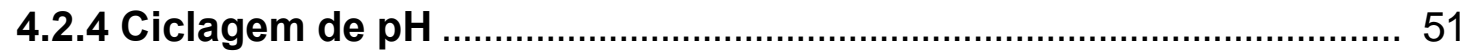


4.2.5 Preparo dos espécimes de para análise ao Microscópio de Luz

Polarizada (MLP)

52

4.2.5.1 Avaliação das alterações microestruturais das lesões artificiais de cárie oclusal 53

4.2.6 Análise estatística ........................................................................... 55

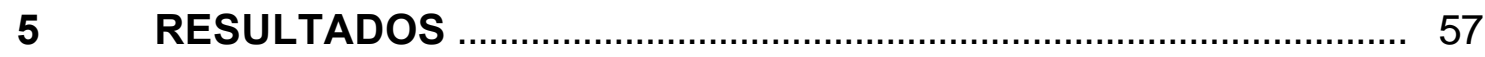

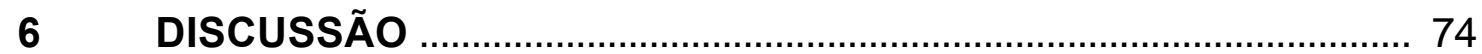

6.1 Avaliação do potencial cariostático dos selantes resinosos e dos cimentos ionoméricos utilizados para selamento de sulcos e fissuras 74

6.2 Avaliação do potencial cariostático do verniz fluoretado e do diamino

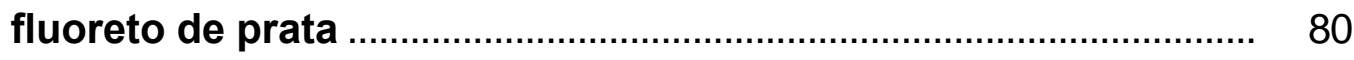

7 CONCLUSÕES ……………....................................................... 91

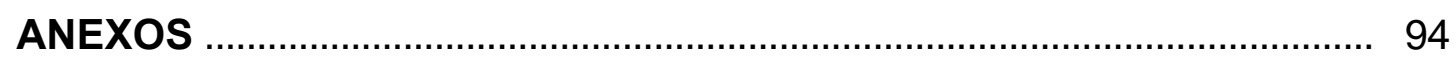

REFERÊNCIAS BIBLIOGRÁFICAS .............................................................. 98

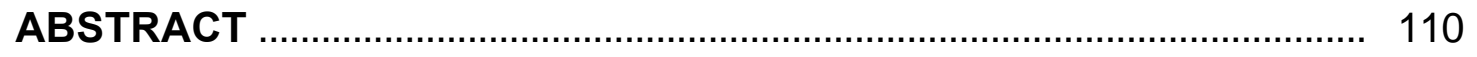

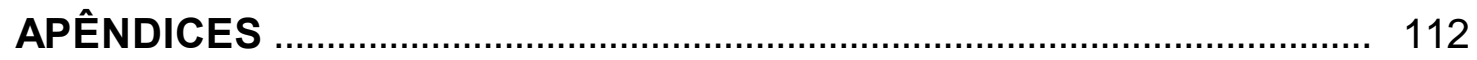




\section{LISTA DE ILUSTRAÇÕES}

Figura 1 - Fluxograma do experimento 48

Figura 2 - Diagrama descrevendo a técnica de mensuração. As setas mostram os pontos nos quais foram realizadas as medidas de profundidade na área da lesão

Figura 3 - Média de profundidade da lesão $(\mu \mathrm{m})$ nas amostras dos 7 grupos estudados 60

Figura 4 - Média de área da lesão $\left(\mu \mathrm{m}^{2}\right)$ nas amostras dos 7 grupos estudados ... 60

Figura 5 - Fotomicrografia em secção longitudinal de uma lesão de cárie artificial na fissura de um espécime do Gl. No detalhe observa-se a área de birrefringência positiva laranja (setas). Notar no canto inferior direito dispositivo para a análise quantitativa.

Aumento 50x 61

Figura 6 - Fotomicrografia em secção longitudinal de uma lesão de cárie artificial na fissura de um espécime do Gll (setas).

Aumento 50x 62

Figura 7 - Fotomicrografia em secção longitudinal de uma lesão de cárie artificial na fissura de um espécime do GIll (setas).

Aumento 50x

Figura 8 - Fotomicrografia em secção longitudinal de uma lesão de cárie artificial na fissura do espécime do GIV (setas).

Aumento 50x

Figura 9 - Fotomicrografia em secção longitudinal de uma lesão de cárie artificial na fissura do espécime do GV (setas).

Aumento 50x 65

Figura 10 - Fotomicrografia em secção longitudinal de uma lesão de cárie artificial na fissura do espécime do GVI (setas).

Aumento 50x 66

Figura 11 - Fotomicrografia em secção longitudinal de uma lesão de cárie artificial na fissura do espécime do GVII (setas).

Aumento 50x 
Figura 12 - Fotomicrografia em secção longitudinal mostrando a remineralização de uma lesão de cárie artificial na fissura de um espécime do GIII. No destaque nota-se a área de birrefringência negativa azul-esverdeada (setas) indicativa de remineralização de lesão de cárie. Aumento 50x

Figura 13 - Fotomicrografia em secção longitudinal mostrando a remineralização de uma lesão de cárie artificial na fissura de um espécime do GIV (setas). Aumento 50x

Figura 14 - Fotomicrografia em secção longitudinal mostrando a remineralização de uma lesão de cárie artificial na fissura de um espécime do GV (setas). Aumento 50x

Figura 15 - Fotomicrografia em secção longitudinal mostrando a remineralização de uma lesão de cárie artificial na fissura de um espécime do GVI (setas). Aumento 50x

Figura 16 - Fotomicrografia em secção longitudinal mostrando a remineralização de uma lesão de cárie artificial na fissura de um espécime do GVII (setas). Aumento 50x

Tabela 1 - Média de distribuição do aspecto microscópico das lesões artificiais de cárie quanto àsua profundidade $(\mu \mathrm{m})$ nas amostras dos 7 grupos estudados 58

Tabela 2 - Média de distribuição do aspecto microscópico das lesões artificiais de cárie quanto àsua área $\left(\mu \mathrm{m}^{2}\right)$ nas amostras dos 7 grupos estudados

Quadro 1 - Média e desvio-padrão dos dados de profundidade da lesão (ì m) para os 7 grupos estudados

Quadro 2- Média e desvio-padrão dos dados de área da lesão (ì m²) para os 7 grupos estudados

Quadro 3-Resultados da Prova de Kruskal-Wallis para profundidade da lesão ..114

Quadro 4-Resultados da Prova de Kruskal-Wallis para área da lesão

Quadro 5 - Resultados do Teste de Comparações Múltiplas de Dunn a 5\% para comparar tratamentos dentro do fator Profundidade

Quadro 6-Resultados do Teste de Comparações Múltiplas de Dunn a 5\% para comparar tratamentos dentro do fator Área 


\section{LISTA DE ABREVIATURAS, SIGLAS E SÍMBOLOS}

\begin{tabular}{|c|c|}
\hline BisGMA & Bisfenol A de glicidil metacrilato \\
\hline $\mathrm{CaF}_{2}$ & Fluoreto de Cálcio \\
\hline CIV & Cimento de lonômero de Vidro \\
\hline CPO-D & Índice de Cárie - dente cariado; perdido; obturado \\
\hline DFP & Diamino Fluoreto de Prata \\
\hline FFA & Flúor Fosfato Acidulado \\
\hline In situ (latim & ) em sítio, no local \\
\hline In vivo (latim & ) no ser vivo \\
\hline In vitro (latim & n) em laboratório \\
\hline $\mathrm{MB}$ & Mancha Branca \\
\hline MEV & Microscópio Eletrônico de Varredura \\
\hline MLP & Microscópio de Luz Polarizada \\
\hline $\mathrm{MPa}$ & Mega Pascal \\
\hline $\mathrm{N}$ & Newton \\
\hline $\mathrm{NaF}$ & Fluoreto de Sódio \\
\hline $\mathrm{p}$ & nível de significância \\
\hline ppmF & partes por milhão de flúor \\
\hline "primer" & agente formador da camada híbrida \\
\hline ART & Técnica Restauradora Atraumática \\
\hline á & alfa \\
\hline$\mu \mathrm{g} / \mathrm{cm}^{2}$ & micrograma por centímetro quadrado \\
\hline$\mu \mathrm{m}$ & micrômetro \\
\hline
\end{tabular}


RESUMO 


\section{RESUMO}

O objetivo deste trabalho foi avaliar, in vitro, ao Microscópio de Luz Polarizada (MLP), o potencial cariostático dos selantes resinosos, dos cimentos ionoméricos, do diamino fluoreto de prata e do verniz fluoretado aplicados em superfície oclusal de molares permanentes humanos. Para tanto, 70 terceiros molares humanos hígidos, extraídos por razões clínicas, foram divididos aleatoriamente em sete grupos $(\mathrm{N}=10)$ : GI - controle (sem selamento); Gll - selante resinoso sem flúor Delton ${ }^{\circledR} ; \mathrm{G}$ III selante resinoso fluoretado Fluroshield $\circledast$; GIV - cimento de ionômero de vidro (CIV) de presa rápida Ketac Molar $\AA^{\circledR}$; GV - CIV modificado por resina Vitremer ${ }^{\circledR}$; GVI solução de diamino fluoreto de prata (DFP) a 30\% Safluoride $®$; GVII - verniz fluoretado a 2,26\% Duraflur ${ }^{\circledR}$. Após profilaxia com jato de bicarbonato, os materiais foram aplicados na superfície oclusal, de acordo com as orientações dos fabricantes, sendo os dentes impermeabilizados com verniz com exceção da área das fissuras e de $1 \mathrm{~mm}$ ao redor das mesmas, sendo submetidos a ciclagens de desremineralização durante 14 dias. Após a ciclagem, foram seccionados e as secções obtidas lixadas, polidas e embebidas em água durante 36 horas, para análise ao MLP, sendo medidas transversalmente nas fotografias, a profundidade $(\mu \mathrm{m})$ e a área $\left(\mu \mathrm{m}^{2}\right)$ da lesão através de grade quadriculada em seis pontos padronizados ao longo da lesão. As médias das 6 medidas foram calculadas nos 7 grupos e comparadas estatisticamente através do teste não-paramétrico de Kruskal-Wallis e de Comparações Múltiplas de Dunn, ao nível de $5 \%$ de probabilidade $(p<0,05)$. Observou-se diferença estatisticamente significante $(P=0.000000372)$ a nível de profundidade da lesão $(H=50,5)$ com menores valores para o GVII $(0,29 \mu \mathrm{m})$, GVI $(0,61 \mu \mathrm{m})$ e GV $(0,89 \mu \mathrm{m})$ em comparação aos materiais do GIV $(3,69 \mu \mathrm{m})$, Gll $(3,67 \mu \mathrm{m})$ e GIII $(2,10 \mu \mathrm{m})$ que não diferiram do $\mathrm{Gl}(5,81 \mu \mathrm{m})$. Quanto à área da lesão, houve diferença estatisticamente significante $(P=0.0000256 ; H=51,3)$, com os menores valores para os tratamentos do GV $\left(0,81 \mu \mathrm{m}^{2}\right)$, GVII $\left(1,78 \mu \mathrm{m}^{2}\right)$, GVI $\left(2,86 \mu \mathrm{m}^{2}\right)$, GIV $\left(3,69 \mu \mathrm{m}^{2}\right)$ e GIII $\left(4,91 \mu \mathrm{m}^{2}\right)$, comparados ao Gll $\left(16,39 \mu \mathrm{m}^{2}\right)$ e GI $\left(24,04 \mu \mathrm{m}^{2}\right)$, que não diferiram entre si. Concluiu-se que, os materiais fluoretados são eficazes em controlar o início e/ou a progressão da lesão de cárie na superfície oclusal quando comparados com o selante resinoso sem flúor e o não selamento. 
1 INTRODUÇÃO 


\section{INTRODUÇÃO}

A prevalência e a severidade da cárie dentária têm mostrado um declínio durante as últimas décadas na maioria dos países industrializados e mesmo naqueles em processo de desenvolvimento, como o Brasil. Esse fato foi confirmado no último estudo epidemiológico realizado pelo Ministério da Saúde em 1996, que demonstrou uma queda de $53,22 \%$ do $C P O-D$ brasileiro aos doze anos, em relação a 1986 (PINTO ${ }^{91}$, 1997). Embora as razões para essa redução não estejam ainda integralmente esclarecidas e dimensionadas, certamente $\mathrm{o}$ aumento e a universalização do uso de fluoretos em suas variadas formas de aplicação, apresentam uma relação direta com esse fenômeno (GIBBONS ${ }^{41}, 1996$ e WEYNE ${ }^{127}$, 1997).

Entretanto, segundo MURRAY; RUGG-GUNN ${ }^{78}$ (1976), os tratamentos com produtos fluoretados são particularmente eficazes na prevenção da lesão de cárie em superfícies dentárias lisas e proximais, mas apresentam menos eficiência nas fissuras. Desse modo, a superfície oclusal é a mais susceptível ao processo da cárie dentária (BERMAN; SLACK $\left.{ }^{10}, 1973\right)$.

Pesquisas demonstraram que a superfície oclusal do primeiro molar permanente é o sítio da dentição mais freqüentemente atacado pela cárie dentária (NIKIFORUK 82, 1985 e FEHR ${ }^{30}$, 1986), com maior incidência nesse dente, ocorrendo desde o seu surgimento na cavidade bucal até três anos após sua erupção (PARFITT ${ }^{87}, 1956$ e BERMAN; SLACK ${ }^{10}$, 1973). Dentre os fatores relacionados à vulnerabilidade da superfície oclusal de molares permanentes em estágio de erupção, FENNIS-LE et al. ${ }^{31}$ (1998) destacaram o fechamento incompleto das fissuras, baixo grau de maturação do esmalte e retenção de placa 
bacteriana nestes sítios. Embora se acredite que a susceptibilidade àlesão de cárie de dentes em erupção esteja relacionada à maturaçã o pré e pós-eruptiva do esmalte (CARVALHO et al. ${ }^{17}$, 1989), as condições favoráveis ao acúmulo de placa bacteriana desempenham um papel mais expressivo, ou seja, as características locais são importantes fatores na iniciação e na progressão da lesão de cárie e o acúmulo local de placa bacteriana é essencial para que esse processo ocorra ${ }^{22,40,70}$. O acúmulo de placa bacteriana é maior na superfície oclusal dos molares do início da erupção até o estabelecimento da oclusão e, nesse sentido, este deve ser o período de maior risco para o começo da lesão de cárie de sulcos e fissuras ${ }^{6,16,17}$, $34,43,62,118$.

LUSSI ${ }^{67}$, em 1991, relatou que, na última década, houve redução de apenas 26 \% da incidência de lesão de cárie na superfície oclusal em comparação aos $50 \%$ de redução observados nas superfícies proximais em crianças. WENDT; $\mathrm{KOCH}{ }^{126}$ (1988) afirmaram, ainda, que $60 \%$ de todas as restaurações estão localizadas na região oclusal, embora a área total destas superfícies compreendam apenas $12,5 \%$ de todas as superfícies dentárias. Considera-se que a alta susceptibilidade à lesão de cárie da região oclusal, comparada com as superfícies lisas, estaria relacionada æ̀ irregularidades estruturais dos sulcos e fissuras (NEWBRUN ${ }^{81}, 1983$ e NIKIFORUK ${ }^{82}$, 1985), geralmente considerados como falhas ou imperfeições na odontogênese das cúspides (TAYLOR; GWINNETT ${ }^{117}$, 1973). Também, ঝ̀ configurações geométricas dessa região que são bastante variáveis, podendo ser rasas ou profundas, com formato de "V" amplo ou forma estreita e constrictiva, que algumas vezes têm a terminação bulbosa podendo ter uma direção ondulante ou terminar a poucos micrômetros da junção amelo-dentinária, ou mesmo ao nível da dentina (GILLINGS; BUONOCORE ${ }^{44}, 1961$ ). 
Devido a essa complexa anatomia, o diagnóstico da presença ou não de lesão de cárie nessa superfície foi considerado bastante problemático (LUSSI ${ }^{67}$, 1991). Pela impossibilidade de uma remoção eficaz da placa bacteriana nesta área, alguns métodos invasivos foram utilizados no passado com o objetivo de se não eliminar ao menos minimizar este problema (MALTZ; CARVALHO $\left.{ }^{68}, 1997\right)$.

Contudo, NAGANO ${ }^{79}$ (1961) demonstrou que as lesões de cárie desenvolvem-se nas paredes laterais da entrada dos sulcos e fissuras, local de acesso à remoção de placa bacteriana e ação do flúor *, indicando que a ocorrência de lesão de cárie estaria ligada à presença de placa bacteriana e não à forma anatômica dessa região. Estas observações têm importância clínica na medida em que indicam a possibilidade de controle de lesão de cárie na superfície oclusal como em qualquer superfície dentária.

Assim, desde que observações clínicas comprovaram que lesões de mancha branca são reversíveis, principalmente em um meio onde há íon flúor disponível, a remineralização passou a ser um importante mecanismo na prevenção e redução das lesões de cárie em esmalte ${ }^{28,40,55,123,125}$. Dentro desta filosofia, é possível encontrar no mercado odontológico vários produtos com flúor na sua composição, como: os selantes resinosos fluoretados, os CIV convencionais, os CIV modificados por resina, os CIV de presa rápida, as soluções a base de diamino fluoreto de prata e os vernizes fluoretados, entre outros.

A incorporação de flúor aos selantes oclusais foi introduzida por ZIMMERMAN; RAWLS; BASSETT ${ }^{132}$ (1984) e teria por finalidade não apenas o selamento dos sulcos e fissuras, mas também a liberação deste íon, de modo a

\footnotetext{
* Termo genérico para definir as formas iônica (fluoreto) e ionizada do elemento flúor.
} 
propiciar uma conjugação de métodos de reconhecida eficácia na prevenção da cárie dentária. Basicamente, o método de incorporação de flúor envolve um composto orgânico do íon que é quimicamente unido àestrutura polimérica insolúvel do selante resinoso. O flúor é liberado através de trocas iônicas com a saliva.

O CIV ou cimento de polialcenoato de vidro foi desenvolvido por WILSON; KENT ${ }^{128}$ em 1971. A composição deste material é complexa e variada, mas todos apresentam como princípio uma reação química ácido-base. A inclusão de componentes resinosos resultou nos CIV modificados por resina, ou híbridos, os quais podem apresentar de 2 a 3 reações de presa: uma reação ácido-base normal dos ionômeros convencionais, uma reação por fotoativação dos radicais livres, que pode ainda continuar com uma polimerização química da fase resinosa (MOUNT ${ }^{77}, 1994$; NAVARRO; PASCOTTO $\left.{ }^{80}, 1998\right)$.

O uso do CIV para selamento de sulcos e fissuras tem aumentado nos últimos anos, devido a sua propriedade de liberação de flúor que aumenta a resistência à lesão de cárie dos sulcos e fissuras de dentes recém irrompidos, mesmo após a perda parcial ou total do material (SEPPÄ; FORSS ${ }^{102}$, 1991; FRENCKEN et al. ${ }^{36}, 1994$; FORSS; HALME $^{34}$, 1998).

Assim, em dentes recém irrompidos onde o controle da umidade é crítico e por um período determinado de tempo, o CIV pode exercer um efeito cáriepreventivo, particularmente em pacientes com alta atividade de cárie dentária (KRAMER; FELDENS; ROMANO $\left.{ }^{66}, 1997\right)$.

A solução de diamino fluoreto de prata ou fluoreto de amônia de prata foi introduzida por Yamaga e Yokomizo em 1969 (BIJELLA et al. ${ }^{12}$, 1991) e, desde então, este composto vem sendo apontado como um agente eficaz, tanto na 
prevenção quanto na paralisação de lesões de cárie em sulcos e fissuras (BIJELLA et al. ${ }^{12}$, 1991; ALMEIDA ${ }^{2}$, 1993 e SANT'ANNA et al. $\left.{ }^{98}, 2001\right)$.

Este produto apresenta como características principais ser líquido, incolor, ter $\mathrm{pH}$ ao redor de 8.0 e possuir propriedades cáusticas (ROCHA et al. ${ }^{95}$, 1999). Seu mecanismo de ação baseia-se na atuação dos seus dois principais constituintes: o nitrato de prata $\left(\mathrm{AgNO}_{3}\right)$, que tem potente ação de coagulação da proteína (YAMAGA et al. ${ }^{129}$, 1972; SUZUKI et al. ${ }^{114,115}$, 1976a e 1976b) e o fluoreto de sódio (NaF), que na reação com o esmalte dentário forma $\mathrm{CaF}_{2}$ e fosfato de prata $\left(\mathrm{AgPO}_{4}\right)$ que ficam precipitados na superfície do dente, agindo como uma resistência contra a cárie dentária (YAMAGA et al. ${ }^{129}, 1972$; SUZUKI et al. ${ }^{115}$, 1976b e HIHARA; NISHINO ${ }^{53}$, 1994). Já o fosfato de prata produzido caracteriza-se por ser um cristal amarelo, insolúvel, que por ação de agentes redutores ou da luz pigmenta-se, tornando-se escurecido ${ }^{96,97 .}$

Outro método preventivo de lesão de cárie de sulcos e fissuras que tem atraído um interesse crescente dos pesquisadores é a aplicação tópica de vernizes com flúor. Comparada com outras formas de aplicação tópica, o verniz proporciona uma exposição prolongada ao flúor, aderindo-se àregião mais profunda dos sulcos e fissuras, permitindo uma alta incorporação deste íon ao esmalte (HOLM et al. ${ }^{54}$, 1984). Segundo SKÖLD et al. ${ }^{108}$ (1994), o flúor tem boa capacidade de prevenir a ocorrência de lesão de cárie e sua progressão de camadas mais superficiais para camadas mais profundas do esmalte. Sua biodisponibilidade está relacionada à solubilidade natural do composto fluoretado em que ele se encontra. Os íons livres de flúor interagem com os diversos minerais que compõem o esmalte depositandose de diferentes formas, tanto na estrutura sadia quanto na desmineralizada $24,25,26$. 
A maior parte do flúor que é retido no dente após a aplicação tópica é na forma de $\mathrm{CaF}_{2}$, que age como um reservatório controlado pelo $\mathrm{pH}$ liberando flúor para remineralização durante o processo de desmineralização (SONGPAISAN et al. ${ }^{110}$, 1995). A aplicação de verniz fluoretado, segundo vários autores ${ }^{7,}$ 8, 14, 15, 42, 46, 71, 92, 93, 94, 101, 108 , é um método usual para prover suporte de flúor em alta concentração, sendo os mesmos considerados agentes com boas propriedades preventivas em relação àcárie dentária.

Estudos clínicos prévios demonstraram o efeito preventivo do verniz fluoretado na prevenção de lesão de cárie na superfície oclusal de primeiros molares permanentes recém irrompidos 13,14, 15, 46, 54, 92, 108, 130. Resultados similares também foram obtidos in vitro $4,5,23,65,93,103$.

Assim sendo, em face do exposto, o objetivo do presente estudo in vitro é avaliar, comparativamente, a eficácia de diferentes tratamentos da superfície oclusal de molares permanentes humanos, como: os selantes resinosos com e sem flúor, os cimentos ionoméricos, a solução de diamino fluoreto de prata e o verniz com flúor, com relação ao potencial cariostático dos mesmos em situações de alto desafio cariogênico. 
2 REVISÃO DE LITERATURA 


\title{
2 REVISÃO DE LITERATURA
}

Será dividida em quatro partes, apresentando um levantamento bibliográfico das pesquisas que avaliaram o efeito cariostático e preventivo dos selantes resinosos com e sem flúor, dos cimentos ionoméricos, da solução de diamino fluoreto de prata e do verniz fluoretado, quando aplicados na superfície oclusal.

\subsection{SELANTES RESINOSOS COM E SEM FLÚOR}

\author{
Segundo HOROWITZ ${ }^{57}$ (1984): \\ "Os selantes são resinas sintéticas, fluidas, que, quando aplicadas na \\ superfície oclusal do dente, atuam como uma barreira física, impedindo que \\ microrganismos e seus substratos provindos do meio ambiente bucal, entrem \\ em contato com as estreitas ranhuras dos sulcos e fissuras, dificultando \\ dessa forma a formação de ácidos associados com o início do processo de \\ cárie dentária."
}

HICKS; SILVERSTONE ${ }^{51}$ (1982) ao analisarem comparativamente in vitro os selantes quimicamente polimerizáveis e os fotopolimerizáveis observaram uma menor incidência de lesão de cárie nos dentes selados com os materiais polimerizados por luz. Os autores concluíram que, mesmo após a perda do selante fotopolimerizável, permaneciam tags resinosos na interface esmalte-selante, sendo os mesmos responsáveis pelo aumento da resistência do esmalte ao ataque de cárie dentária produzida pelo selante. MERTZ-FAIRHURST et al. ${ }^{72}$ (1984) também 
relataram vantagem dos selantes fotopolimerizáveis sobre os quimicamente ativados, pois devido a eliminação do processo de mistura da base com o catalisador, atenua-se a incorporação de bolhas de ar no material.

Com a finalidade de avaliar a efetividade da colocação de selante resinoso sobre lesões de mancha branca $(\mathrm{MB})$ para impedir a progressão da lesão, GOEPFERD; OLBERDING ${ }^{45}$ (1989) selecionaram 15 dentes humanos hígidos para o experimento in vitro, onde foram preparadas 25 áreas para exposição ao meio ácido. Lesões de MB foram induzidas na superfície do esmalte e posteriormente parte da MB foi selada para comparação da progressão da lesão nas duas áreas. Após o selamento, os dentes foram novamente expostos ao gel ácido por um tempo adicional de 6 semanas. A profundidade da lesão inicial e das lesões seladas não diferiram significativamente, indicando que as lesões de MB que são protegidas com o selante não progridem quando expostas novamente ao meio ácido. As lesões não seladas quando re-expostas ao meio ácido apresentaram uma progressão adicional de $33 \mu \mathrm{m}$ ( $51 \%$ de aumento de profundidade), indicando que tem desafio ácido suficiente para continuar o processo de desmineralização. Desta forma, os autores concluíram que o ataque ácido das lesões de MB seguido da aplicação de um selante resinoso pode ser um método eficaz para impedir a progressão desta lesão.

COOLEY et al. ${ }^{18}$ (1990) avaliaram in vitro ao MEV o selante fluoretado Fluroshield $\AA$ comparado com o selante sem flúor Helioseal $\AA$, com relação à microinfiltração e liberação de flúor. Eles observaram que todos os espécimes liberaram fluoreto durante o período de uma semana e que esta liberação diminuiu pela metade ao terceiro dia, estabilizando-se em aproximadamente $1 \mu \mathrm{g} / \mathrm{cm}^{2}(0,41$ ppm) ao final de 2 dias. No exame ao MEV, o selante fluoretado não se adaptou tão 
bem æ̀̀ paredes dos sulcos e fissuras, quanto o não fluoretado. Este fato também refletiu no estudo de microinfiltração, no qual o selante fluoretado permitiu microinfiltração na maioria dos espécimes, fato que não foi observado nas amostras do selante não fluoretado.

JENSEN et al. ${ }^{60}$ (1990) examinaram em seu estudo in vitro, o efeito do selante fluoretado Fluroshield ® na desmineralização do esmalte comparado com o não fluoretado Prismashield $\AA$. Os autores observaram, a partir dos resultados obtidos, que o selante fluoretado pode ser eficaz em prevenir a desmineralização adjacente ao selante. As lesões artificiais de cárie obtidas foram estatisticamente menores em profundidade e área do que as do grupo controle sem flúor.

PIMENTA; PAVARINI; TÁRZIA ${ }^{89}$ (1991) avaliaram a quantidade de liberação de íon flúor do selante Fluroshield $\AA^{\circledR}$, após os períodos de 30 minutos, 2, 24 horas, 2, 3, 4 e 5 dias de incubação em água destilada e observaram que o fluoreto liberado foi mínimo, menos de 1 ppm, observado até o período de incubação de 24 horas, tornando-se depois, estável e diminuindo até atingir zero deste período em diante. Os autores concluíram então, que a liberação de flúor pelo selante era de valor não significativo para propósitos terapêuticos.

HICKS; FLAITZ ${ }^{48}$ (1992) com a finalidade de avaliar os efeitos de um selante fluoretado (Fluroshield $(\circledR)$ e de um ionômero de vidro (Ketac-Fil (B) comparado com um selante convencional (Prisma Shield ${ }^{\circledR}$ ) no início e na progressão de lesões de cárie em esmalte, confeccionaram preparos de classe $\mathrm{V}$ em 40 pré-molares humanos restaurando-os com os respectivos materiais e observaram ao microscópio de luz polarizada, a formação de lesões incipientes de cárie ao redor 
das restaurações. A profundidade da lesão superficial foi reduzida de modo significante nos grupos do selante com flúor e no de CIV, em comparação ao selante convencional. Os pesquisadores concluíram que um material odontológico contendo flúor em sua composição quando colocado adjacente à superfície dentária poderá fornecer maior resistência ao início e progressão das lesões de cárie.

VAN DORP; TEN CATE ${ }^{122}$ (1992) compararam, in vitro, ao MLP e através de radiografias, selantes de sulcos e fissuras a base de BisGMA (Delton $\AA^{\circledR}$ e White Sealant $($ ) com tratamentos fluoretados (verniz fluoretado Duraphat $®$ e Elmex Protector Fluid $\AA^{8}$ contendo $1,23 \%$ de flúor) quanto a sua eficácia em inibir ou reduzir a progressão de lesão de cárie em sulcos e fissuras de molares humanos. Foram utilizados terceiros molares inclusos sendo classificados pelo padrão dos sulcos e fissuras em: rasas, rasas com alguns sulcos profundos e fissuras estreitas e profundas. No grupo controle, a superfície oclusal foi deixada sem tratamento. Após profilaxia com pedra pomes, os dentes foram incluídos em resina epóxica, protegidos com verniz ácido-resistente deixando expostas apenas uma janela de esmalte na área oclusal e outra na superfície lisa. Os dentes foram radiografados e imersos por um período de 9 semanas em solução desmineralizante. Após a aplicação dos respectivos tratamentos propostos, os espécimes foram submetidos a 5 semanas adicionais de desmineralização e novamente radiografados. A análise das radiografias dos dentes tratados após 14 semanas mostrou uma superioridade do selamento em relação aos outros tratamentos em reduzir a progressão das lesões de cárie nas paredes dos sulcos e fissuras quando o selante estava intacto, tendo 0 grupo do Delton ${ }^{\circledR}$ apresentado maior progressão lateral da 
desmineralização do que 0 do White Sealant ${ }^{\circledR}$. Ao MLP, os resultados demonstraram que nos grupos que receberam os tratamentos de produtos fluoretados, a extensão da lesão de cárie permaneceu limitada àregião dos sulcos e fissuras, em contraste com o grupo controle.

PIMENTA; TÁRZIA; PAVARINI ${ }^{90}$ (1992) avaliaram a resistência da estrutura dentária ao ataque ácido após a remoção do selante Fluroshield $\AA_{\text {, através }}$ da quantificação de cálcio, fósforo e fluoreto liberado após 6, 12, 24 e 48 horas de tratamento ácido. Os autores não observaram diferença significativa entre este grupo tratado com o selante fluoretado e o controle, tratado com selante não fluoretado (Prismashield $\AA$ ) em nenhum dos tempos testados, concluindo que o selante resinoso fluoretado não é suficiente para aumentar a proteção do esmalte à cárie dentária, após a sua remoção, desse modo, o efeito protetor de ambos os selantes estaria restrito àsua ação mecânica no esmalte.

DECICO et al. ${ }^{22}$ (1994) avaliaram in vitro o selante fluoretado Fluroshield $\AA$ quando submetido a ciclagens térmicas e de des-remineralização, em relação ao seu potencial cariostático através da análise de microdureza do esmalte. Após 14 dias, os blocos de esmalte foram avaliados e os autores concluíram a partir dos resultados obtidos, que o flúor liberado pelo selante foi capaz de reduzir a perda mineral de regiões não seladas, sugerindo que o mesmo possa ter significado clínico quando da perda do selante convencional.

FIGUEIREDO; PAVARINI ${ }^{32}$ (1996) avaliaram microscopicamente a penetração de tags resinosos no esmalte da superfície oclusal, dos selantes Delton $\AA$ e Fluroshield $\AA$ em 80 pré-molares hígidos extraídos e observaram um 
padrão de penetração estatisticamente superior do selante Delton ® em relação ao Fluroshield $₫(p<0,01)$, concluindo que os selantes sem carga apresentam melhor penetração nos sulcos e fissuras do que os selantes com carga.

GARCIA-GODOY et al. ${ }^{39}$ (1997) avaliaram durante 30 dias, a quantidade e o padrão de fluoreto liberado em água destilada, de 5 marcas comerciais de selante: Fluroshield $\AA$, Helioseal-F $\AA$, Ultraseal XT $\AA$, Baritone L3 $\AA$ e Teethmate- $\mathrm{F} \AA$, tendo o selante Delton ${ }^{\circledR}$ como controle. Todos os selantes fluoretados liberaram quantidades de íon flúor durante o período-teste de forma similar, sendo que a maior quantidade de fluoreto foi liberada nas primeiras 24 horas após a mistura, caindo bruscamente no segundo dia e decrescendo lentamente nos últimos dias.

HICKS; FLAITZ 49 (1998) comparando um selante fluoretado (Fissurit-F () e um convencional (Fissurit @) aplicado em preparos cavitários de classe $\mathrm{V}$ em molares decíduos, observaram ao MLP uma melhor performance do selante fluoretado em reduzir o início e a progressão da lesão de cárie ao longo da interface esmalte-selante quando comparado com o controle.

COUTINHO; PEREIRA; BIJELLA ${ }^{19}$ (1999) estudaram o grau de microinfiltração e a profundidade de penetração in vitro de dois materiais seladores: Delton ${ }^{\circledR}$ e Fluroshield $\AA$ em 20 terceiros molares hígidos inclusos, extraídos por razões clínicas. Ambos os selantes apresentaram microinfiltração tanto em sulcos e fissuras rasas quanto profundas, sem diferença estatística entre eles. Quanto à profundidade de penetração, o Delton \$ obteve $83 \%$ de penetração total nos sulcos e fissuras rasas e $50 \%$ nas profundas, enquanto que o Fluroshield $\AA, 41 \%$ e $0 \%$, 
respectivamente, sendo esta diferença significante. Os autores concluíram que ambos os materiais não foram capazes de prevenir a microinfiltração, porém o selante sem carga Delton ${ }^{\circledR}$ foi estatisticamente superior ao com carga (Fluroshield (B) em penetrar tanto nos sulcos e fissuras rasas quanto nas profundas.

HICKS; FLAITZ; GARCIA-GODOY ${ }^{52}$ (2000) avaliaram in vitro os efeitos de um selante resinoso fluoretado (Fissurit-F ${ }^{\circledR}$ ) e de um selante resinoso convencional não fluoretado (Fissurit $®$ ) na formação de cárie artificial em esmalte em 12 molares hígidos que foram seccionados em 4 fragmentos. Preparos cavitários foram realizados nas superfícies bucais e linguais, feito o condicionamento ácido e restaurados com os respectivos selantes: (1) nas porções mesio-bucal e mesiolingual, com o selante fluoretado; (2) nas porções disto-bucal e disto-lingual, com o não fluoretado. Os fragmentos foram termociclados em saliva artificial e imersos em gel acidificado para a formação da lesão de cárie artificial. Foram feitas secções após 6 semanas de exposição ao gel para avaliação da formação da lesão de cárie e após 9 semanas, para avaliação da progressão da lesão, sendo avaliadas ao microscópio de luz polarizada. As médias de profundidade da lesão diferiram significativamente entre os grupos tanto em relação ao início (119 ì m e 157 ì m para o grupo 1 e 2, respectivamente), quanto em relação à progressão da lesão (169 ì m e 221 ì m, respectivamerte). Os autores concluíram que o selante contendo flúor apresentou um efeito inibidor da lesão de cárie com uma redução significativa da profundidade da lesão na superfície do esmalte adjacente ao material, agindo como um reservatório de flúor a ser liberado no meio ambiente bucal. 


\subsection{CIMENTOS DE IONÔMERO DE VIDRO (CIV) PARA SELAMENTO DE SULCOS E FISSURAS}

Ao analisar através da microscopia ótica, a microinfiltração em sulcos e fissuras seladas com cimento ionomérico Fuji III ${ }^{\circledR}$ comparado com o selante resinoso Concise $\AA$, ÖVREBÖ; RAADAL ${ }^{86}$ (1990) observaram extensa microinfiltração nas amostras seladas com Fuji III ® tanto na interface dente/cimento, quanto através do cimento. Quanto ao resinoso, não havia microinfiltração em 93\% dos dentes selados e em 7\%, a microinfiltração foi superficial. As autoras concluíram que o cimento ionomérico teve pouca retenção nos sulcos e fissuras, permitindo a ocorrência de microinfiltração mesmo quando totalmente retido, apesar de que onde o cimento era classificado como totalmente perdido havia remanescente do mesmo no fundo dos sulcos e fissuras.

SEPPÄ; FORSS ${ }^{102}$ (1991) avaliaram in vitro a resistência de sulcos e fissuras à desmineralização após a perda do selamento com CIV. As autoras utilizaram 10 terceiros molares e 30 pré-molares hígidos extraídos por razões clínicas que foram seccionados longitudinalmente, perfazendo um total de 71 sulcos e fissuras que foram aleatoriamente divididas em 3 grupos: I - controle, sem selamento; II - selamento com Fuji III $\AA$; e III - abertura dos sulcos e fissuras com broca diamantada em forma de chama (diâmetro de $0,5 \mathrm{~mm}$ ) e selamento igual ao grupo II. Após 1 semana de armazenamento em água destilada, os selantes foram removidos completamente com uma sonda afiada até que nenhum material permanecesse visível macroscopicamente nos sulcos e fissuras. As amostras foram 
protegidas com verniz ácido-resistente com exceção do esmalte ao redor dos sulcos e fissuras e imersas durante 7 semanas em solução desmineralizante. Após este período, as amostras foram seccionadas longitudinalmente, lixadas e avaliadas ao MLP quanto à profundidade da lesão. As médias obtidas de profundidade da lesão para os grupos I, II e III foram 143, 93 e $75 \mu \mathrm{m}$, respectivamente. As autoras concluíram que os sulcos e fissuras seladas com CIV são mais resistentes à desmineralização, mesmo após a perda macroscópica do material, como resultado do efeito combinado do flúor liberado pelo CIV e o material residual no fundo dos sulcos e fissuras.

SARDI et al. ${ }^{99}$ (1995) estudaram in vivo e in vitro, o desempenho do CIV modificado por resina Vitremer ${ }^{\circledR}$ como selante de sulcos e fissuras. Os autores observaram, após 6 meses, 31,57\% de retenção total in vivo, 47,35\% de perda parcial e $21,05 \%$ de perda total. In vitro, o cimento penetrou em toda a extensão dos sulcos e fissuras em $85,5 \%$ das amostras, em $2 / 3$ da profundidade dos sulcos e fissuras em 13,04\% e em menos de 1/3, em 1,44\%. Face a estes resultados, os autores recomendaram o Vitremer $\AA$ como material selador de sulcos e fissuras, principalmente, em pacientes com alta atividade cariogênica.

Um estudo in vitro realizado por MOORE et al. ${ }^{76}$ (1995) comparou a penetração nos sulcos e fissuras, a habilidade seladora e a resistência à abrasão provocada pela escovação de três materiais seladores: dois cimentos ionoméricos fotopolimerizáveis (Fuji II LC $\AA$ e Vitremer $\AA$ ) e um selante resinoso convencional fotopolimerizável (Concise $\left.\AA^{\circledR}\right)$. Após os testes laboratoriais, não foi encontrada diferença significante na capacidade de penetração nos sulcos e fissuras entre o Fuji II LC $\AA$ e o Vitremer ${ }^{\circledR}$, porém, comparando-os com o Concise ${ }^{\circledR}$, os cimentos 
ionoméricos apresentaram uma penetração nos sulcos e fissuras significativamente melhor. Quanto à microinfiltração, os três materiais não apresentaram diferença significante. Quanto à abrasão, o Vitremer ${ }^{\circledR}$ apresentou maior perda quando comparado com o Fuji II LC ${ }^{\circledR}$ e estes em relação ao Concise ${ }^{\circledR}$, apresentaram menor resistência àabrasão e àescovação.

JOHNSON et al. ${ }^{61}$ (1995) examinaram o efeito da variação na proporção pó-líquido de um CIV modificado por resina experimental (3M Dental) usado como selante de sulcos e fissuras, na sua penetração. Oitenta terceiros molares permanentes extraídos foram divididos aleatoriamente em quatro grupos: no grupo I (controle), os dentes foram selados com Delton ${ }^{\circledR}$ (selante resinoso); e nos grupos II, III e IV, com o CIV modificado por resina foto-ativado experimental, com proporções pó-líquido de 1.4:1.0, 1.8:1.0 e 2.0:1.0, respectivamente. Cada grupo foi composto de 20 dentes. Posteriormente à aplicação dos materiais com seringa Centrix, os dentes sofreram termociclagem (2.500 ciclos), foram imersos em solução de azul de metileno a $1 \%$ durante 4 horas em temperatura ambiente, seccionados e a extensão da penetração do corante foi medida linearmente ao longo da interface esmalte-selante através de um sistema de imagem digital (Vidas 2.1 software). Os autores observaram que os sulcos e fissuras seladas com o selante resinoso Delton ${ }^{\circledR}$ mostraram menos penetração, estatisticamente significante, do que a observada nos três grupos de diferentes proporções de pó-líquido do CIV experimental. $\mathrm{O}$ Delton ${ }^{\circledR}$ mostrou menos de $1 \%$ de penetração do corante enquanto os grupos do ionômero experimental demonstraram de $67 \%$ a $79 \%$ de penetração. Entre os grupos II, III e IV, o grupo III (1.8:1.0) foi o que obteve a maior penetração 
do corante, sendo estatisticamente significante $(79,9 \%)$ em comparação com o grupo II $(67,4 \%)$ e IV $(69,7 \%)$

VELASCO; NÖR; FIGUEIREDO $124 \quad$ (1996) avaliaram microscopicamente a penetração do Fuji IX ${ }^{\circledR}$ e do Vitremer ${ }^{\circledR}$ aplicados em sulcos e fissuras, após profilaxia com jato de bicarbonato de sódio e condicionamento ácido da superfície adamantina com gel de ácido fosfórico a 37\% por 15 segundos. Os dentes foram seccionados e após o exame das amostras, os autores concluíram que o Fuji IX $®$ apresentou melhor desempenho no selamento quando comparado com o Vitremer ${ }^{\circledR}$.

Também em 1996, FIGUEIREDO et al. ${ }^{33}$ analisaram com um potenciômetro (Orion-940), a capacidade de liberação de flúor de materiais ionoméricos (Vitremer ${ }^{\circledR}$, Fuji II LC ${ }^{\circledR}$ e Fuji IX $\left.{ }^{\circledR}\right)$ tendo como controle a resina P 50 ®. Dez corpos de prova foram confeccionados para cada material sendo mantidos em recipientes plásticos contendo $5 \mathrm{ml}$ de saliva artificial por períodos de $1,5,10,15,20,25$ e 30 dias. Os resultados demonstraram que todos os materiais liberaram significativamente mais flúor do que o controle, sendo que o Fuji IX $\AA$ liberou significativamente menos flúor do que o Fuji II LC ${ }^{\circledR}$ e o Vitremer ${ }^{\circledR}$ em todos os períodos testados.

YIP ${ }^{131}$ (1996), também verificando a liberação deste íon em quatro CIV modificados por resina (Dyract ${ }^{\circledR}$, Fuji II LC ${ }^{\circledR}$, Photac Fil ${ }^{\circledR}$ e Vitremer ${ }^{\circledR}$ ) e um CIV especialmente desenvolvido para a ART (Fuji IX $\left.{ }^{\circledR}\right)$, observou após 22 dias, que todos os materiais liberaram inicialmente, alta concentração de flúor, principalmente nas primeiras 24 horas, decrescendo esta liberação de forma exponencial no decorrer do experimento, e continuando posteriormente de forma lenta, até o $22^{\circ}$ dia. 
O autor encontrou a seguinte ordem de liberação de flúor: Photac Fil ${ }^{\circledR}>$ Fuji II LC ${ }^{\circledR}$ > Vitremer ${ }^{\circledR}>$ Fuji IX ${ }^{\circledR}>$ Dyract ${ }^{\circledR}$.

Em 1997, GAO; SMALES; LAM ${ }^{37}$ estudaram a capacidade de liberação e incorporação de flúor de quatro CIV (Fuji IX ®, Fuji IX GP ®, Fuji IX GP ® encapsulado e Ketac Molar Prototype $\left.{ }^{\circledR}\right)$ utilizados na ART. Os autores concluíram que todos os materiais analisados liberam mais flúor nas duas primeiras semanas, mantendo-se estável esta liberação mesmo após 5 semanas. Dos CIV testados, o Fuji IX GP ® encapsulado apresentou a maior liberação. Quando submetidos a aplicações tópicas de gel de flúor-fosfato acidulado (FFA), houve um aumento na liberação do íon de cerca de 2,5 a 3 vezes.

TANTBIROJN; DOUGLAS; VERSLUIS ${ }^{116}$ (1997) avaliaram in vitro a distância que um CIV modificado por resina seria capaz de exercer seus efeitos cariostáticos em lesões artificiais em esmalte bovino. Dez incisivos bovinos foram seccionados no sentido longitudinal, sendo que uma metade foi restaurada com Vitremer ${ }^{\circledR}$ no terço cervical da face vestibular e como controle, a outra metade foi restaurada com um selante resinoso experimental. Após imersão em solução desmineralizante pelo período de 3 semanas, os dentes foram avaliados através do método de microdureza Knoop em secção longitudinal nas distâncias de 0,2, 0,5, 1,0, 2,0, 4,0 e 7,0 mm da margem da restauração. Os autores observaram uma inibição da desmineralização nas amostras restauradas com CIV em todas as distâncias testadas, quando comparado com o controle, sendo mais pronunciada na distância de 1,0 $\mathrm{mm}$ do CIV, embora um efeito remoto tenha sido detectado até a distância de $7 \mathrm{~mm}$. 
SMALES; GAO; HO ${ }^{109}$ (1997) compararam in vitro, através da análise de microinfiltração e do grau de penetração do selante nos sulcos e fissuras, a performance de 4 ionômeros convencionais especialmente desenvolvidos para a ART - Fuji IX $₫$, Fuji IX GP $\AA$, Fuji IX GP $®$ encapsulado e Ketac Molar Prototype ${ }^{\circledR}$ - com o selante resinoso Delton ® e concluíram que este só apresentou menos microinfiltração, estatisticamente significante, quando comparado com o Fuji IX GP $\AA$, no entanto, todos os ionômeros testados obtiveram melhor penetração nos sulcos e fissuras do que o selante resinoso Delton ${ }^{\circledR}$.

ABREU ${ }^{1}$ (1997) avaliou a profundidade de penetração de quatro materiais œntendo ionômero de vidro utilizados como selantes de sulcos e fissuras em 40 pré-molares superiores hígidos divididos em 4 grupos: I - Vidrion C ®; II Fuji IX $\AA$; III - Vitremer $\AA^{\circledR}$; e IV - Vitro Seal Alpha ${ }^{\circledR}$. A autora concluiu a partir dos resultados obtidos que o Vitremer $\AA$ penetrou mais efetivamente nos sulcos e fissuras, quando comparado com o Vidrion C $\AA$ e o Fuji IX $®$. Não verificou diferença estatística entre Vidrion $C \AA$ e Vitro Seal Alpha $\AA ;$ Fuji IX $\AA$ e Vitro Seal Alpha $\AA$ e também, entre o Vitremer $\AA^{\circledR}$ e Vitro Seal Alpha ${ }^{\circledR}$.

MONICO; TOSTES ${ }^{74}$ (1998) estudaram, ao microscópio óptico, a penetração e a microinfiltração do Fuji IX ® em diferentes formas de sulcos e fissuras de 20 terceiros molares. As autoras mostraram que há uma maior penetração nos sulcos e fissuras em "U" e em "V", e menor nos sulcos e fissuras em "l", sendo estatisticamente significante. Foi verificada uma penetração total do material em $53 \%$ das amostras, sem levar em consideração as formas dos sulcos e 
fissuras. Quanto à ocorrência de microinfiltração, foi observada uma maior microinfiltração nas fissuras em "V" e "U”, e menor nas fissuras em "l”.

TOSTES AMARAL ${ }^{119}$ (1999) estudou in situ a remineralização nas margens de sulcos e fissuras seladas com CIV Fuji IX $®$ comparado com o selante resinoso Delton ${ }^{\circledR}$ através da análise da microdureza Knoop do esmalte. A amostra consistiu de 88 blocos de esmalte obtidos de terceiros molares humanos previamente desmineralizados e divididos em 5 grupos: Grupo I - controle, sem tratamento; Grupo II - amostras submetidas ao processo de cárie artificial; Grupo III - igual ao Grupo II porém selados com Delton ®; Grupo IV - igual ao Grupo II porém selados com CIV; Grupo V - igual ao grupo II, mas sem selamento. Os Grupos I e II não foram submetidos ao meio bucal e serviram como controle, o Grupo IV foi inserido no dispositivo intra-bucal e os blocos do Grupo $V$ foram inseridos no dispositivo intra-bucal junto com os blocos do grupo III. Após 30 dias, foi realizada a análise de microdureza com carga estática de $25 \mathrm{~g}$ por 15 segundos em 3 penetrações, desde a base da fissura até uma abertura de $600 \mathrm{~mm}$ preestabelecida entre os planos inclinados das cúspides, considerando-se também a forma dos sulcos e fissuras, classificadas em "l”, "U” e "V". A autora observou a recuperação da dureza (remineralização) apenas no grupo do Fuji IX ® (Grupo IV), em todas as distâncias testadas, sendo estatisticamente significante $(p<0.05)$. Não houve diferença nos resultados obtidos com o CIV (Grupo IV), em relação à remineralização, nos sulcos e fissuras em "I" e "U”, entretanto, nas fissuras em "V", um menor endurecimento foi observado com o selamento com CIV. Na análise ao MLP, encontrou diminuição da birrefringência positiva em algumas áreas do Grupo IV (CIV), quando comparado aos demais grupos. 
HICKS; FLAITZ ${ }^{50}$ (2000) compararam in vitro a formação de cárie oclusal adjacente a um CIV modificado por resina (PH-SE II ®) e a um selante resinoso fluoretado (Helioseal $F \quad \AA$ ) em 12 molares inferiores não expostos à cavidade bucal. Cada dente foi seccionado buco-lingualmente em duas porções mesial e distal. A superfície oclusal da porção mesial foi selada com o CIV modificado e a porção distal, com o selante resinoso sendo avaliadas ao MEV para verificar a adaptação do material. Após termociclagem (500 ciclos) em saliva artificial, foram formadas lesões de cárie artificiais e secções longitudinais foram feitas para comparar a formação da lesão adjacente aos materiais. As médias de profundidade das lesões nas superfícies oclusais foram de $64 \pm 17 \mathrm{~mm}$ para o CIV modificado por resina e de $116 \pm 27 \mathrm{~mm}$ para o selante resinoso, sendo a diferença estatisticamente significante $(\mathrm{p}<0.05)$. Ao MEV, foi observada adaptação adequada dos materiais testados nos sulcos e fissuras. Os autores concluíram que ambos os materiais protegeram o esmalte dos sulcos e fissuras em relação ao desenvolvimento de lesão de cárie, porém o CIV modificado por resina reduziu a extensão do envolvimento da lesão no esmalte oclusal adjacente não selado, quando comparado com o selante resinoso.

FRACASSO 35 (2001) comparou qualitativamente, in vitro, a microinfiltração marginal (MM) e a profundidade de penetração (PP) dos cimentos de ionômero de vidro (CIV) e de um selante resinoso (SR) em 72 terceiros molares divididos em 6 grupos experimentais: 1 - condicionamento com ácido fosfórico 37\% / Delton $\circledast ;$; 2 ácido poliacrílico 40\% / Ketac Molar $\circledast$ / esmalte de unha; 3 - Fuji Plus

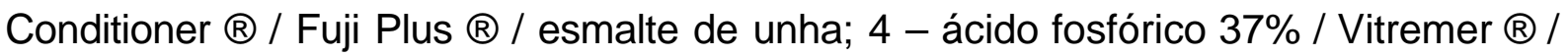
Finishing gloss $\AA ; 5$ - ácido fosfórico 37\% / "primer" / Vitremer $\AA^{\circledR}$ / Finishing gloss $\AA$; 
e 6 - ácido fosfórico 37\% / Vitremer ® diluído na proporção de 1/4de pó / Finishing gloss $\AA^{\circledR}$. Após 24 horas em água deionizada, os dentes sofreram ciclagens térmicas (300 ciclos de 15 segundos cada) e imersão no corante de fucsina básica 0,5\% por 24 horas, sendo então seccionados e avaliados quanto ao grau de penetração do corante na interface esmalte / material selador através do uso de escores. A autora concluiu que não houve diferença estatística entre os materiais testados em relação àPP, com os CIV obtendo escores máximos de 4.0 e escores mínimos de 3.0, embora apresentassem maior viscosidade do que o SR. Com relação à MM, os CIV dos grupos 2, 3, 4 e 5 apresentaram, de maneira geral, os menores valores de microinfiltração, correspondendo ao menor índice de penetração do corante, sem diferença estatística entre eles, mas com superioridade estatística dos mesmos sobre o SR (grupo 1), que apresentou penetração de corante maior e mais severa, em praticamente todos os espécimes do seu grupo. Já o grupo 6 ocupou uma posição intermediária, condizente a um índice de microinfiltração de suave a severo, entretanto, nenhum material selador foi capaz de impedir a total penetração do corante.

\subsection{SOLUÇÃO DE DIAMINO FLUORETO DE PRATA (DFP)}

NISHINO ${ }^{83}$, em 1969, testou in vitro a aplicação tópica pelo período de 5 minutos da solução de DFP a $38 \%$ sobre o esmalte e dentina, através de análise cristalográfica por raio-X. O autor observou a formação de fluoreto de cálcio e sedimentação de fosfato de prata. Relatou ainda, um aumento na resistência à 
descalcificação do esmalte e da dentina bem como, uma diminuição do grau de amolecimento das amostras que receberam a solução, constatado pela análise da dureza, quando comparado com o controle. No mesmo trabalho, ele observou in vivo, em molares inferiores de ratos albinos que apresentavam cavidades abertas de cárie até a dentina, uma paralização média de $65 \%$ na progressão da lesão de cárie após a aplicação da mesma solução por 4 minutos, quando comparado com o grupo controle (água destilada), no qual as lesões atingiram estágios avançados.

OKAMOTO; MONOMURA; SOBUE ${ }^{85}$ (1975) utilizaram o DFP a $38 \%$ e observaram, através do MEV, de difração de raio $-X$ e de análise de conteúdo de flúor do esmalte sadio, um acúmulo de micro e macro depósitos que consideraram ser fosfato de prata e fluoreto de cálcio. O conteúdo médio de flúor na camada superficial de $10 \mu \mathrm{m}$ aumentou de 568 ppm para 1953 ppm, diminuindo para 820 ppm após 3 semanas imersos em água destilada. Após 5 semanas, os autores relataram que estes depósitos podiam ser dissolvidos da estrutura adamantina, concluindo que o DFP, quando aplicado no esmalte hígido, pode ser eficaz na prevenção da cárie dentária.

NISHINO; MASSLER ${ }^{84}$ (1977) realizaram um estudo em ratos, demonstrando que o DFP tinha tanto um poder preventivo quanto de paralisação da cárie em sulcos e fissuras susceptíveis à cárie dentária. Os ratos foram submetidos a uma dieta altamente cariogênica durante 14 das, sendo aplicadas, então, as seguintes soluções: DFP a 38\%, fluoreto estanhoso a $8 \%$ e nitrato de prata amoniacal. Como grupo controle, água destilada. Nos molares tratados com DFP e fluoreto estanhoso houve uma diferença significante na prevenção da cárie dentária comparada com o grupo controle, o que não aconteceu com o nitrato de prata 
amoniacal. Na paralisação da lesão de cárie porém, o fluoreto estanhoso não demonstrou efeitos significativos, o que demonstra que o DFP tem os dois efeitos preventivo e cariostático - enquanto que o fluoreto estanhoso só tem efeito preventivo. $\mathrm{O}$ nitrato de prata amoniacal demonstrou não ter efeito nem preventivo e nem cariostático.

IGARASHI ${ }^{59}$ (1978) realizou um estudo bacteriológico com a finalidade de avaliar as mudanças na distribuição proporcional do Streptococcus mutans na placa bacteriana após a aplicação de Saforide ${ }^{\circledR}$ (DFP a 38\%). O estudo foi feito através da coleta de placa bacteriana da superfície dentária de 101 crianças de 2 a 5 anos com e sem aplicação do agente para testar o seu efeito antimicrobiano. Este também foi estudado in vitro, utilizando o teste de susceptibilidade antimicrobiana com a técnica do disco de papel, tendo como controles o nitrato de prata, o fluoreto estanhoso e o fluoreto de sódio. Os resultados demonstraram que o DFP foi o inibidor mais eficaz dentre os agentes testados, porque aumentou a resistência à cárie da superfície dentária além de possuir efeito antimicrobiano sobre os Streptococcus mutans da placa bacteriana.

Também com o objetivo de avaliar possíveis alterações na proporção de Stretococcus mutans de placas interproximais de molares decíduos e permanentes, TSUTSUMI ${ }^{120}$ (1981a) aplicou por 3 minutos uma solução de DFP a $38 \%$ em manchas brancas produzidas artificialmente em blocos de esmalte utilizando como controles, o fluoreto estanhoso e o fluoreto de sódio. O autor constatou significante redução no número de Streptoccus mutans e inibição da aderência e crescimento bacteriano com o uso do DFP em comparação com os dois fluoretos testados. 
Em um segundo experimento, TSUTSUMI ${ }^{121} \quad$ (1981b) aplicou Saforide ${ }^{\circledR}$ com auxílio de fio dental em superfícies proximais e através de controle clínico e radiográfico, observou significante redução na incidência e na progressão das lesões de cárie proximal de esmalte dos molares tanto decíduos quanto permanentes, após 18 meses, constatando que aplicações tópicas múltiplas desse produto podem ser efetivas para o controle de lesões de cárie nessas superfícies.

GARBELINI $^{38}$ (1989) pesquisou os efeitos do diamino fluoreto de prata a 30\% na progressão e incidência de cárie dentária em molares de ratos e observou redução na incidência das lesões em esmalte e em dentina superficial comprovando o efeito anticariogênico da solução, além da paralisação no progresso das lesões, evidenciando o efeito cariostático do mesmo e diminuição da atividade microbiana.

BIJELLA et al. ${ }^{12}$ (1991) avaliaram o efeito da aplicação deste composto a $12 \%$ na dentição decídua e sua influência na incidência de lesão de cárie em primeiros molares permanentes. Foi observada uma expressiva ação cariostática da solução nos dentes decíduos, com redução de 38,05\% (aplicação semestral) a 69,02\% (aplicação trimestral) e diminuição na incidência de lesão de cárie nos primeiros molares de $43,93 \%$ a $63 \%$. Os autores consideraram então, ser este um agente cariostático, anticariogênico e bactericida, revertendo o processo de lesão de cárie ativa e protegendo os dentes permanentes que irão irromper.

ANDRADE et al. ${ }^{3}$ (1992) verificaram a reação da dentina cariada humana após aplicação do diamino fluoreto de prata a 10\%. Os resultados observados através do MEV demonstraram que houve uma intensa diminuição da quantidade de microrganismos e uma melhor reestruturação dentinária, semelhante a um processo de cárie dentária estacionário, passando a lesão de uma fase ativa 
para um estágio de cronicidade. Não verificaram evidências clínicas ou radiográficas de necrose pulpar e afirmaram que este agente pode ser utilizado em cavidades profundas desde que apresente baixa concentração. Os autores chamaram a atenção para o fato de que nos casos de cárie rampante, o aparecimento de abcessos após o uso do agente deve-se provavelmente ao estado irreversível em que a polpa se encontra, já que neste caso, vários são os dentes destruídos e nem todos apresentam necrose após o uso da solução.

BIJELLA; SILVA; MACHADO ${ }^{11}$ (1993) realizaram uma revisão de literatura sobre o uso tópico de DFP, ressaltando sua indicação como um agente paralizador da cárie dentária em crianças com cárie precoce de infância. As autoras relataram que este procedimento torna-se importante nestes casos, uma vez que tratamentos restauradores na faixa etária de 0 a 30 meses muitas vezes é difícil, pela imaturidade da criança, que na maioria das vezes não colabora com o profissional.

ALMEIDA $^{2}$ (1993) avaliou, durante um ano, os efeitos cariostático e anticariogênico da solução de DFP a 12\% aplicada trimestralmente em dentes decíduos e superfícies oclusais de primeiros molares permanentes parcialmente ou recém irrompidos, em crianças de risco, na faixa etária de 5 1/a 6 anos, do município de Bauru - SP. O efeito antimicrobiano sobre os estreptococos mutans e os lactobacilos também foi avaliado através de testes salivares obtidos no início e durante o estudo. A autora observou um efeito cariostático e anticariogênico da solução aplicada nos dentes decíduos e nos molares permanentes recém irrompidos. Quanto ao efeito antimicrobiano, houve diminuição nos níveis salivares dos estreptococos mutans nas crianças que receberam a solução em todos os 
dentes presentes na cavidade bucal exceto os primeiros molares permanentes (grupo I). Nas crianças do grupo II que receberam aplicações nos dentes decíduos e nas do grupo III que receberam aplicações apenas nos primeiros molares permanentes, não foi encontrada diferença estatisticamente significante em relação a estes microrganismos, sendo observado o mesmo resultado com relação aos lactobacilos nos 3 grupos.

SIQUEIRA; SPERANÇA ${ }^{107}$ (1997), através do teste pelo contato direto, procuraram avaliar comparativamente a capacidade inibitória das soluções de ferrocianeto de potássio a $5 \%$, de ferrocianeto de prata, de nitrato de prata a $2 \%$ e de diamino fluoreto de prata a $10 \%$, tendo como grupo controle um selante resinoso (Alpha Seal $®$ ), sobre Streptococcus faecalis, Streptococcus faecalis liquefaciens e Streptococcus mutans B-13 tipo B, tipo D, SE-13 tipo E e SE-11 tipo F. Os resultados demonstraram que as soluções de ferrocianeto de potássio a $5 \%$, de ferrocianeto de prata, de nitrato de prata a $2 \%$ e de diamino fluoreto de prata a $10 \%$ foram eficazes em inibir o crescimento dos microrganismos testados, porém, na prova do poder germicida, apenas as soluções de nitrato de prata a $2 \%$ e de diamino fluoreto de prata a $10 \%$ mostraram poder bactericida em todos os tempos testados (30 segundos, 1 e 3 minutos), enquanto que o selante mostrou-se ineficaz nos testes realizados.

SOUSA NETTO; ALMEIDA; CURY $112 \quad$ (1999) avaliaram comparativamente in situ, o potencial de remineralização do diamino fluoreto de prata a $30 \%$ (Safluoride di Walter $($ ) ) e do verniz fluoretado a 2,26\% (Duraphat $\AA$ ) em dentina bovina desmineralizada artificialmente e exposta no meio bucal durante 15 dias, através da análise de microdureza Vickers. Os resultados mostraram que 
ambos os materiais testados tiveram potencial remineralizador da dentina bovina, porém o diamino fluoreto de prata a 30\% apresentou um maior índice de recuperação da microdureza superficial, sendo estatisticamente significante $(p<$ 0.0001), quando comparado com o verniz fluoretado a 2,26\%.

MONTANDON; SPERANÇA ${ }^{75}$ (2000) compararam in vitro, a atividade antimicrobiana e o poder germicida do DFP em três concentrações: a $10 \%$, a $12 \%$ e a 30\%, sobre cepas de Streptococcus mutans dos tipos B, D, E, F, sendo o nitrato de prata a $2 \%$ o controle positivo e o selante autopolimerizável Alpha Seal ${ }^{\circledR}, 0$ negativo. Na prova de difusão no ágar de triptona de soja, os maiores diâmetros para os halos de inibição foram encontrados para o DFP a 30\%, seguido pelo DFP a $12 \%$ e, os menores, para o DFP a $10 \%$ e para o nitrato de prata a $2 \%$. Com relação à prova do poder germicida, foram realizadas contagens que variaram de 30 segundos a um ou três minutos. O DFP a $30 \%$ foi o único que mostrou-se bactericida em todos os intervalos de tempos testados e para todos os tipos de microrganismos estudados.

\subsection{VERNIZES FLUORETADOS}

Em um dos primeiros estudos sobre vernizes fluoretados, HEUSER; SCHMIDT ${ }^{47}$ (1968) observaram que após uma única aplicação de verniz fluoretado Duraphat $\AA$ em ratos albinos alimentados com uma dieta cariogênica por 45 dias, houve uma redução da freqüência de lesão de cárie de sulcos e fissuras em cerca de $70 \%$. 
KOCH; PETERSSON ${ }^{63}$ (1972) avaliaram, in vitro, a absorção de flúor pelo esmalte humano após 1, 3, 6 e 12 horas da aplicação de verniz fluoretado Duraphat ${ }^{\circledR}$. As maiores concentrações de flúor foram encontradas na camada mais externa do esmalte após a desmineralização com ácido perclórico. No grupo experimental, a concentração média de flúor variou de 3800 e 2250 ppmF, comparado com 1150 ppmF do grupo controle. A aquisição de flúor pelo esmalte tendeu a ser maior após a exposição de 12 horas, principalmente na profundidade de $20-50 \mu \mathrm{m}$.

YANOVER ${ }^{130}$ (1982), ao realizar uma revisão de literatura sobre vernizes fluoretados, afirma que os vernizes parecem ser a forma mais simples e rápida de aplicar flúor tópico. Além disso, a segurança do produto não é questionável, não tendo sido observado efeitos colaterais após a sua aplicação e tendo os valores plasmáticos ficado bem abaixo dos considerados tóxicos. Sua habilidade em reduzir a cárie oclusal é um benefício não conseguido comumente com outros regimes de aplicação tópica de flúor. Esta propriedade pode estar relacionada simplesmente a uma retenção física na superfície oclusal ou a uma ação antibacteriana contra os microrganismos presos nos sulcos e fissuras oclusais. Considerando a estabilidade do flúor do verniz após uma semana e a profundidade de penetração, o seu efeito anticariogênico é compreensível.

SEPPÄ; LUOMA ${ }^{103}$ (1983) avaliaram o conteúdo de flúor e a liberação de cálcio pelo esmalte, após a aplicação de verniz fluoretado Duraphat ${ }^{\circledR}$, Fluor Protector ${ }^{\circledR}$ ou verniz placebo em molares de 195 ratos Osborne-Mendel que foram alimentados com uma dieta cariogênica durante 42 dias. Nos dias 19 e 20, os ratos 
foram inoculados com Streptococcus mutans ATCC 27351. Nos dias 19-21 e 25-27, os grupos experimentais receberam aplicação dos respectivos vernizes. O grupo controle não recebeu nenhum tratamento. Após o período experimental, as autoras observaram que o conteúdo de flúor no esmalte foi maior nos grupos tratados com verniz fluoretado, principalmente, com o Fluor Protector $\circledR$. No entanto, a liberação de cálcio pelo esmalte e a incidência de lesão de cárie de sulcos e fissuras foram significantemente reduzidas no grupo do Duraphat ${ }^{\circledR}$ quando comparado com os demais grupos.

Com relação ao efeito preventivo do verniz fluoretado Duraphat ${ }^{\circledR}$ na superfície oclusal de primeiros molares recém irrompidos, HOLM et al. ${ }^{54}$ (1984) observaram que este agente foi efetivo tanto em sulcos e fissuras rasas quanto profundas, com redução de $56 \%$ da incidência de cárie dentária, sendo o verniz considerado pelos autores, uma medida preventiva aconselhável para primeiros molares permanentes recém irrompidos.

MÖLLER; SCHRÖDER ${ }^{73}$ (1986) observaram ao MEV a superfície de lesões naturais de cárie proximal de subsuperfície antes e após tratamento e a remineralização em um modelo in situ. A amostra consistiu de 9 pré-molares que apresentavam cárie proximal subsuperficial, não detectável radiograficamente e que foram extraídos por motivos ortodônticos. Em 7 amostras, metade de cada lesão foi estudada diretamente ao MEV servindo como controle da lesão antes da remineralização e a outra metade foi remineralizada in situ antes da observação ao MEV. Em 2 amostras, a mesma superfície foi estudada antes e após a remineralização. As amostras foram fixadas na superfície vestibular dos primeiros e 
segundos molares dos autores com resina. Enquanto os espécimes permaneceram na cavidade bucal, foi mantida uma higiene bucal efetiva. $O$ tratamento remineralizador in situ consistiu de bochecho diário de fluoreto de sódio a 0,05\%, uso de dentifrício fluoretado com $0,1 \%$ de fluoreto de sódio e aplicação de verniz fluoretado Duraphat ${ }^{\circledR}$ a cada 10 dias durante 8 a 10 semanas. O resultado clínico demonstrou redução no tamanho da lesão, com superfícies lisas e brilhantes após o período de 810 semanas. Ao MEV, as superfícies remineralizadas apresentaram uma aparência mais regular e homogênea com cristais maiores e compactados comparado com as lesões não tratadas, o que indicou a reversão da lesão de cárie não só superficialmente, mas também nas partes mais profundas da mesma.

HOLMEN et al. ${ }^{56}$ (1986) avaliaram o efeito da aplicação de verniz fluoretado Duraphat (B) em lesões ativas subsuperficiais incipientes produzidas experimentalmente in vivo durante um período de 4 semanas em 9 pares de prémolares homólogos com extração indicada por motivos ortodônticos. A amostra constituiu-se de 9 pacientes de 11 a 15 anos. Bandas ortodônticas foram cimentadas nos pré-molares com cimento de policarboxilato (Ceramco $\left.{ }^{\circledR}\right)$, após profilaxia com pedra-pomes, sendo inseridos no interior das mesmas, dois pinos de metal de 0,8 $\mathrm{mm}$ com a finalidade de assegurar um espaço entre a banda e o dente, a fim de permitir acúmulo de placa. As bandas permaneceram na cavidade bucal por 4 semanas, nas quais os pacientes não tiveram contato com nenhum produto fluoretado e nem participaram de qualquer programa preventivo. Após este período, um dente foi extraído para controle. No dente remanescente foi realizada a remoção da banda, profilaxia com pedra-pomes para remover a placa, recimentação da 
mesma e aplicação do verniz com uma seringa, seguindo-se um novo período experimental de 2 semanas, quando então o dente foi extraído. Os autores observaram ao MLP e ao MEV, redução na porosidade subsuperficial da lesão após a aplicação do verniz em comparação ao controle, com marcante redistribuição de minerais no interior das lesões de cárie, com penetração de fluoreto nas áreas mais profundas da lesão.

De BRUYN et al. ${ }^{21}$ (1988) estudaram in situ a influência de vários vernizes fluoretados na perda mineral sob a placa bacteriana. Os vernizes estudados foram o Flúor Protector \& com as concentrações de $0,7 \%, 0,1 \%$ e $0,05 \%$, e o Duraphat $®$ a 2,26\%, no período de 2, 4 e 6 meses. Ao final de cada período experimental, microradiografias eram realizadas e a perda mineral, a profundidade da lesão e a distribuição de mineral no esmalte desmineralizado foram medidas. Não foram observadas diferenças entre as diversas concentrações do Flúor Protector ® após 4 e 6 meses. Após 4 meses, estes mostraram melhor propriedade protetora contra a perda mineral do que o Duraphat $\AA$, o qual não apresentou diferença significativa quando comparado com o grupo controle. Após 6 meses, entretanto, o efeito protetor de todos os vernizes testados foi similar, não apresentando diferença estatisticamente significante. Já no grupo controle, ocorreu um aumento na desmineralização entre o $2^{\circ}$ e o $4^{0}$ mês, mas sem diferença estatística significante entre $04^{\circ}$ e o 6ํำ mês.

SEPPÄ et al. ${ }^{105}$ (1988) estudaram em ratos inoculados com Streptococcus sobrinus, o efeito de suplementos dietéticos (fórmula MIT 200 modificada) fluoretados com 14 ppm de $\mathrm{NaF}$, associados ou não à aplicação tópica 
de verniz fluoretado Duraphat $\AA^{\circledR}$ e de solução de estrôncio, durante 15, 30 e 54 dias em sulcos e fissuras de molares recém irrompidos. A redução de cárie dentária maior e mais significante nos sulcos e fissuras, após o período do estudo, foi observada no grupo do verniz associado ao suplemento dietético de flúor, que apresentou redução de $43 \%$ nas lesões envolvendo a junção amelo-dentinária e de $65 \%$ nas lesões envolvendo a dentina.

Com a finalidade de analisar a influência da saliva na absorção de flúor do verniz, KOCH; HAKEBERG; PETERSSON ${ }^{64}$ (1988) aplicaram in vitro o verniz fluoretado Duraphat ${ }^{\circledR}$ pelo período de 6 horas em superfícies de esmalte seca e molhadas com saliva fresca estimulada. Após este período, as amostras dos dois grupos foram mantidas em saliva sintética a $37^{\circ} \mathrm{C}$ por 1 semana, quando então foi realizada a análise de flúor através do método de ataque ácido. A maior concentração de flúor, estatisticamente significante, foi observada na superfície seca (6638 \pm 657$)$ quando comparada com a superfície com saliva (2495 \pm 244$)$.

SEPPÄ 100 (1988) estudou comparativamente in vitro, a remineralização do esmalte a partir do uso de verniz fluoretado Duraphat ${ }^{\circledR}$ nas concentrações de $2,3 \%$ e $1,1 \%$, uma ou três vezes ao dia e de uma solução de fluoreto de sódio a $0,1 \%$ nove vezes ao dia. Após 9 dias, as amostras foram desmineralizadas por 1 hora e a quantidade de cálcio e flúor foi determinada. Tanto o verniz quanto a solução foram eficazes em prevenir o amolecimento do esmalte, embora com uma maior eficácia para o primeiro. Três aplicações do verniz a 2,3\% foram mais eficazes do que as de $1,1 \%$, enquanto que uma única aplicação do verniz de $2,3 \%$ foi tão efetivo quanto a de $1,1 \%$. A autora concluiu que a eficácia do 
verniz não é proporcional à concentração de flúor presente no produto, mas sim, ao número de aplicações. O flúor incorporado pelo esmalte foi maior quando do uso do verniz mais concentrado, no entanto, a solubilidade da estrutura adamantina foi diretamente proporcional ao conteúdo do íon em seu interior.

SEPPÄ; FORSS; SORMUNEN ${ }^{104}$ (1989) avaliaram a prevenção de lesão de cárie de sulcos e fissuras em ratos, a partir do uso de verniz fluoretado Duraphat $\circledR$ nas concentrações de 2,3\%, 1,1\% e 0,6\%. Após 40 dias de ingestão de dieta cariogênica, a lesão de cárie de sulcos e fissuras em ratos foi significativamente reduzida apenas nos grupos que receberam aplicação de verniz nas concentrações de $2,3 \%$ e $1,1 \%$ e a progressão da lesão de cárie foi mais lenta com o uso do verniz a 2,3\%.

CRUZ; ÖGAARD; RÖLLA ${ }^{20}$ (1992) compararam in vitro a eficácia do verniz fluoretado Duraphat ${ }^{\circledR}$ e de uma solução de fluoreto de sódio a $2 \%$ na aquisição de flúor solúvel e insolúvel pelo esmalte humano sadio. Os autores concluíram, a partir dos resultados obtidos, que o verniz é tão bom quanto a solução fluoretada, embora mais fluoreto de cálcio tenha sido absorvido pelo esmalte tratado com a solução e não tenha havido formação de fluorapatita em nenhum dos dois procedimentos. Um dado relevante foi que as amostras de esmalte tratadas com verniz, quando imersas em água, liberaram apenas cerca de 50\% dos depósitos de flúor.

SOUZA ${ }^{113}$ (1992) comparou in situ a concentração de flúor (ppm) na forma de fluoreto de cálcio $\left(\mathrm{CaF}_{2}\right)$ formado e retido após 1 e 8 dias da aplicação de gel de FFA a 1,23\% e de verniz de fluoreto de sódio a 2,26\% (Duraphat ß) no 
esmalte humano hígido e desmineralizado, em 6 voluntários com idade entre 23-27 anos. A autora observou uma maior afinidade do flúor pelo tecido desmineralizado, com uma concentração de $\mathrm{CaF}_{2}$ - 4 vezes maior - após 1 dia com o uso do gel comparado ao verniz fluoretado $\left(132,9 \mu \mathrm{gF} / \mathrm{cm}^{2}\right.$ e $36,3 \mu \mathrm{gF} / \mathrm{cm}^{2}$, respectivamente). No entanto, estes valores ficaram semelhantes para ambos os produtos, após 8 dias, tanto sobre o esmalte hígido como sobre o desmineralizado $\left(14,2 \mu \mathrm{gF} / \mathrm{cm}^{2}\right.$ e $31,9 \mu \mathrm{gF} / \mathrm{cm}^{2}$, respectivamente, para o gel e 26,6 $\mathrm{\mu gF} / \mathrm{cm}^{2}$ e $33,6 \mu \mathrm{gF} / \mathrm{cm}^{2}$, respectivamente, para o verniz). A autora sugere, a partir destes resultados, que o gel seria mais apropriado como agente terapêutico por formar maior quantidade de fluoreto de cálcio ativando a remineralização, enquanto o verniz teria uma indicação mais preventiva, formando fluoreto de cálcio mais estável para ser liberado mais lentamente, durante os desafios cariogênicos.

ERONAT; ERONAT; ALPÖZ 27 (1993) realizaram um estudo comparativo in vitro entre 4 produtos fluoretados: um gel de fluoreto de sódio neutro a $2 \%$, um gel de FFA a $1,23 \%$ e dois vernizes fluoretados (Duraphat ${ }^{\circledR}$ e Flúor Protector $\left.\AA^{B}\right)$ e sua relação com a absorção de flúor pelo esmalte humano permanente e decíduo. A amostra constituiu-se de 60 pré-molares hígidos extraídos por motivos ortodônticos e 20 molares decíduos também hígidos. Os dentes foram divididos mesio-distalmente, sendo as superfícies bucais usadas para a aplicação de flúor e as palatinas (ou linguais) para controle, a fim de avaliar o conteúdo de flúor inicial do esmalte. As amostras foram divididas em quatro grupos, contendo 15 espécimes de esmalte permanente e 5 de esmalte decíduo. Após aplicação dos produtos fluoretados, os espécimes foram imersos em saliva artificial durante 24 
horas e, posteriormente, avaliados quanto ao conteúdo de flúor. Os autores concluíram que todos os produtos fluoretados proporcionaram alguma incorporação do íon no esmalte, tanto em dentes permanentes quanto em decíduos, quando comparados com o controle. Contudo, o Duraphat $\AA$ e o gel acidulado foram mais eficazes que os demais compostos avaliados.

SORVARI et al. ${ }^{111}$ (1994) estudaram o efeito in vitro do verniz fluoretado Duraphat $\AA$ e de uma solução experimental fluoretada contendo $1,2 \%$ de fluoreto de sódio na erosão do esmalte humano. Foram utilizados terceiros molares humanos que foram seccionados, sendo uma metade utilizada para os grupos experimentais e a outra para o controle (sem pré-tratamento com flúor). Um total de 23 espécimes constituíram o grupo do verniz fluoretado e 24 , o da solução. O verniz fluoretado foi aplicado, permanecendo em contato com o esmalte por 24 horas, enquanto os espécimes do outro grupo experimental foram imersos na solução fluoretada durante 48 horas. Após os produtos serem removidos do esmalte, os espécimes dos grupos experimentais e do controle foram imersos em Coca-Cola $\AA$ pelos períodos de 1, 4 e 10 minutos, sendo então avaliados ao MEV e através da análise de microdureza Vickers. Os autores observaram que o tratamento prévio do esmalte com flúor antes da imersão em solução ácida promoveu uma inibição da erosão, indicando que ambos os produtos testados foram eficazes em proteger a estrutura adamantina, produzindo um aumento na microdureza do esmalte quando comparado com o esmalte não tratado.

MEDEIROS; MENDONÇA ${ }^{70}$ (1997) testaram in situ a capacidade de quatro vernizes fluoretados (Duraphat $\AA$, Fluor Protector $\AA$, Duraflur $\AA$ e Fluorniz $\AA$ ) 
em depositar fluoreto de cálcio $\left(\mathrm{CaF}_{2}\right)$ solúvel em esmalte dental humano após uma e duas semanas. Realizaram primeiramente uma análise in vitro do total de $\mathrm{CaF}_{2}$ incorporado no esmalte para fins de comparação com o residual encontrado nas lascas de esmalte utilizadas pelos voluntários in situ. Para o estudo in vitro, foram utilizadas 20 lascas de esmalte distribuídas nos quatro grupos experimentais, sendo avaliado o íon fluoreto sob a forma de $\mathrm{CaF}_{2}$ formado e retido no esmalte após 24 horas. No estudo in situ, 100 lascas de esmalte foram utilizadas. Dez voluntários com idade entre 20-28 anos participaram do experimento e os aparelhos intra-bucais foram utilizados pelo período de 7 e 14 dias. Todos os produtos, após os períodos testados, foram capazes de depositar $\mathrm{CaF}_{2}$ sobre o esmalte hígido, no entanto, houve maior incorporação deste composto para as lascas provenientes do estudo in vitro em relação æ̀ da análise in situ, cujos resultados foram decrescentes ao final de uma e duas semanas. Dos produtos testados, o Flúor Protector $\AA$ apresentou os melhores resultados estatisticamente significantes, em ambas as análises: Flúor Protector ${ }^{\circledR}>$ Duraphat $\AA$ > Duraflur $\AA$ > Fluorniz $\AA$.

MEDEIROS; BRUM ${ }^{69}$ (1998) verificaram o potencial erosivo de um refrigerante tipo cola (Coca-Cola $\AA$ ) na superfície do esmalte dental humano e também verificaram comparativamente, a proteção à erosão quando o esmalte é submetido a tratamento prévio com gel de FFA e verniz fluoretado Duraphat ${ }^{\circledR}$. Um total de 60 fragmentos de esmalte obtidos de terceiros molares foram divididos em 4 grupos: TG (tratados com gel), CG (controle gel), TV (tratados com verniz) e CV (controle verniz). Decorridas 5 horas de aplicação dos produtos, os mesmos foram removidos e as amostras imersas na solução ácida pelos períodos de 5, 15, 30 e 60 
minutos, sendo então avaliados ao MEV. Os autores observaram que ambos os produtos ofereceram proteção quanto ao ataque ácido, entretanto, nos primeiros períodos de imersão na solução ácida (até 15 minutos), o verniz fluoretado Duraphat @ mostrou-se mais efetivo no aumento da resistência do esmalte à erosão do que o gel de flúor fosfato acidulado (Odacham $\left.{ }^{\circledR}\right)$.

HUANG et al. ${ }^{58}$ (2001) estudaram o efeito anticariogênico in vitro do uso do laser Nd:YAG combinado com o uso do verniz fluoretado Duraphat ${ }^{\circledR}$ em sulcos e fissuras susceptíveis à cárie. Um total de 36 molares hígidos foram divididos em 4 grupos: tratamento com laser associado ao verniz fluoretado, apenas laser, apenas verniz fluoretado e nenhum tratamento (controle). Lesões de cárie artificial foram criadas para avaliar a resistência do esmalte ao ácido após o tratamento. A formação da lesão (\%), área e profundidade foram avaliadas no MLP. O uso do laser aumentou a resistência do esmalte ao ataque ácido, no entanto, não foi tão eficaz quanto o laser combinado com o verniz fluoretado, sendo que o verniz sozinho inibiu $43 \%$ das lesões de sulcos e fissuras quando comparado com 0 controle.

BERGAMASCHI; DELBEM; SASSAKI ${ }^{9}$ (2001) avaliaram o efeito anticariogênico in vitro do flúor liberado pelo verniz fluoretado a 2,26\% (Duraphat $\circledast$ ) e pela solução de diamino fluoreto de prata a 30\% (Safluoride di Walter ${ }^{\circledR}$ ) utilizando ciclagem de $\mathrm{pH}$. Observaram, através da microdureza do esmalte bovino, que o verniz fluoretado apresentou melhor ação anticariogênica do que o diamino fluoreto de prata, com menor perda mineral $(45,19 \%$ e $53,15 \%$, respectivamente) e maior 
concentração de flúor antes (8091,87ppm e 1389,25ppm, respectivamente) e após (1473,27 ppm e 701,82 ppm, respectivamente) ao desafio cariogênico. 


\section{PROPOSIÇÃO}




\section{PROPOSIÇÃO}

O objetivo deste estudo in vitro foi o de avaliar comparativamente o potencial cariostático dos selantes resinosos (Delton ${ }^{\circledR}$ e Fluroshield ${ }^{\circledR}$ ), dos cimentos de ionômero de vidro (Ketac Molar ${ }^{\circledR}$ e Vitremer $\left.{ }^{\circledR}\right)$, da solução de diamino fluoreto de prata a 30\% (Safluoride di Walter ®) e do verniz de fluoreto de sódio a 2,26\% (Duraflur $\AA$ ), aplicados na superfície oclusal de terceiros molares humanos extraídos, tanto ao nível de profundidade quanto de área da lesão, através do método de microscopia de luz polarizada. 


\section{MATERIAL E MÉTODOS}




\section{MATERIAL E MÉTODOS}

\subsection{MATERIAL}

\subsubsection{Amostra}

Foram utilizados setenta terceiros molares humanos inclusos, extraídos cirurgicamente por razões clínicas, em faculdade de Odontologia, apresentando mais de $2 / 3$ da raiz formada e conservados em formol a $2 \% \mathrm{pH} 7$ desde as extrações. Vale ressaltar que os mesmos foram doados pela Faculdade de Odontologia da Universidade Federal Fluminense para a FOB - USP com finalidade de pesquisa (ANEXO A), tendo a autora assinado um Termo de Compromisso (ANEXO B). O trabalho foi aprovado pelo Comitê de Ética da Faculdade de Odontologia de Bauru - USP (ANEXO C), conforme a Resolução 196/96 do Ministério da Saúde.

Após a remoção de debris, os dentes, com exceção da superfície oclusal, foram polidos com taça de borracha (substituídas a cada cinco dentes), pasta de pedra pomes ultra-fina (SS White Artigos Dentários S.A.) e água, em baixa rotação (micromotor Kavo do Brasil S.A.) durante 20 segundos e lavados com água deionizada, sendo avaliados sob microscópio óptico (Wild Heerbrugg M425475) com aumento 32x onde confirmou-se estarem livres de defeitos, tais como rachaduras, manchas hipoplásicas e opacidade no esmalte. Uma semana antes do experimento, os dentes foram mantidos em água deionizada. 


\subsubsection{Materiais testados na pesquisa}

- Selante Delton ${ }^{\circledR}$ - Distribuído por Dentsply/Caulk - Rio de Janeiro - RJ (Lote 62380)

- Selante Fluroshield ${ }^{\circledR}$ - Distribuído por Dentsply/Caulk - Rio de Janeiro - RJ (Lote 57045)

- Cimento de lonômero de Vidro Ketac Molar ${ }^{\circledR}$ - ESPE DENTAL - Distribuído por DFL Ind. Com. Ltda - Rio de Janeiro - RJ (Lote FW0047716)

- Cimento de lonômero de Vidro Modificado por Resina Vitremer ${ }^{\circledR}$ Distribuído por 3M do Brasil Ltda - Campinas - SP (Lote 19971001)

- Safluoride di Walter $\circledast$ (Diamino fluoreto de prata a 30\%) - Distribuído por Polidental Ind. e Com. Ltda - São Paulo - SP (Lote 002369)

- Verniz Fluoretado Duraflur ${ }^{\circledR}$ (Fluoreto de sódio a 2,26\%)- Distribuído por Dentsply/Caulk - Rio de Janeiro - RJ (Lote 41846)

\subsection{MÉTODOS}

\subsubsection{Delineamento experimental}

O fator em estudo neste trabalho in vitro foi o tratamento não invasivo da superfície oclusal hígida, sendo avaliados seis grupos experimentais e um controle (sem tratamento) e para cada um dos grupos foram selecionados aleatoriamente dez dentes. Em todos os espécimes a instalação e o 
desenvolvimento das lesões de cárie artificial na superfície oclusal foram avaliados quantitativamente, através de Microscopia de Luz Polarizada (MLP), após 14 dias de ciclagem de $\mathrm{pH}$, considerando-se dois fatores: profundidade da lesão (ì m) eárea da lesão (ì m²). O fluxograma (Fig. 1, p. 48) ilustra esse delineamento.

\subsubsection{Determinação dos grupos experimentais}

Os 70 dentes selecionados foram divididos aleatoriamente em sete grupos de dez espécimes cada, assim distribuídos:

Grupo I. Controle - sem selamento.

Grupo II. Delton ${ }^{\circledR}$ - selante de sulcos e fissuras a base de BisGMA sem flúor.

Grupo III. Fluroshield ${ }^{\circledR}$ - selante de sulcos e fissuras a base de BisGMA com flúor.

Grupo IV. Ketac Molar ${ }^{\circledR}$ - cimento de ionômero de vidro de presa rápida utilizado na Técnica Restauradora Atraumática (ART).

Grupo V. Vitremer ${ }^{\circledR}$ - cimento de ionômero de vidro modificado por resina.

Grupo VI. Safluoride di Walter ${ }^{\circledR}$ - solução de diamino fluoreto de prata (Ag $\left.\left(\mathrm{NH}_{3}\right)_{2} \mathrm{~F}\right)$ a $30 \%$.

Grupo VII. Duraflur ${ }^{\circledR}$ - verniz de fluoreto de sódio $(\mathrm{NaF})$ a 2,26\%. 
70 TERCEIROS MOLARES HUMANOS

ㄴ

\begin{tabular}{|c|c|c|c|c|c|c|}
\hline Gl- & Gll- & Glll- & GIV- & GV- & GVI- & GVII- \\
& Selante & Selante & CIV de & CIV & Solução de & Verniz de \\
Controle & BisGMA & BisGMA & presa rápida & modificado & diamino & fluoreto de \\
& sem flúor & com flúor & & por resina & fluoreto de & sódio a \\
& & & & & prata a $30 \%$ & $2,26 \%$ \\
$(10)$ & $(10)$ & $(10)$ & $(10)$ & $(10)$ & $(10)$ & $(10)$ \\
\hline
\end{tabular}

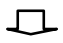

CICLAGEM DE pH - 14 DIAS

$\square$

AVALIAÇÃO EM MICROSCOPIA DE LUZ POLARIZADA

Figura 1 - Fluxograma do experimento

\subsubsection{Tratamento da superfície do esmalte}

No tratamento superficial do esmalte dentário, em todos os dentes foi realizada a profilaxia da região oclusal com o aparelho profilático Prophy $\|{ }^{\circledR}$ (Dabi Atlante S. A.) com fluxo de bicarbonato de sódio utilizado na potência 3, com movimentos intermitentes mésio-distais e disto-mesiais por 20 segundos, a uma distância de cerca de $0,5 \mathrm{~mm}$ da fissura e com angulação de $45^{\circ}$ (ABREU $\left.{ }^{1}, 1997\right)$. 


\subsubsection{Condicionamento do esmalte}

Os dentes dos grupos II e III após terem recebido a profilaxia, foram lavados e secos e tveram a superfície do esmalte na região de sulcos e fissuras oclusais condicionada. Este condicionamento foi realizado utilizando-se ácido fosfórico a $37 \%$ em gel, fornecido pelo fabricante, pelo tempo de 20 segundos. Os dentes foram então lavados com spray água/ar por 40 segundos e secos com jatos de ar da seringa tríplice.

No grupo IV, o condicionamento foi realizado com o próprio líquido do ionômero de vidro, usando bolinha de algodão por 15 segundos. Decorrido este período, os dentes foram lavados com bolinha de algodão embebida em água e secos também com bolinha de algodão, conforme instruções do fabricante para a Técnica Restauradora Atraumática.

No grupo $\mathrm{V}$ foi aplicado na superfície oclusal dos dentes, com pincel descartável (Microbrush ® - KG Sorensen), o primer do mesmo fabricante durante 30 segundos, secos levemente com jato de ar por 15 segundos e expostos por 20 segundos a uma fonte de luz halógena do aparelho fotopolimerizador (Demetron $®$ ), com intensidade de luz de $470 \mathrm{mw} / \mathrm{cm}^{2}$ medida no radiômetro (Demetron ${ }^{\circledR}$ ).

\subsubsection{Aplicação dos materiais}

Completadas as etapas anteriores, os dentes dos grupos II a V receberam os respectivos selamentos, de acordo com as especificações de cada fabricante. 
O selante do grupo II foi levado diretamente à áreas de sulcos e fissuras utilizando-se a ponta aplicadora fornecida pelo fabricante, após a mistura da base com o catalisador com o auxílio de espátula plástica e os materiais dos grupos III, IV e V, com o auxílio de uma sonda exploradora número 5 (Duflex ®). Nos grupos IV e $\mathrm{V}$, o pó e líquido foram manipulados com espátula plástica, em bloco de papel revestido, por 45 segundos. Nos grupos III e V, os materiais foram fotopolimerizados (aparelho Demetron $\AA$ ) pelo tempo de 40 segundos.

O material do grupo IV foi pressionado para dentro dos sulcos e fissuras com o dedo indicador enluvado protegido com vaselina (técnica da pressão digital), deslizando em movimentos suaves de vestibular para lingual e de mesial para distal, sendo mantido em posição até a polimerização do material, quando então foi protegido com o verniz próprio do CIV. Os materiais dos grupos VI e VII foram aplicados empregando-se pincel descartável (Microbrush ${ }^{\circledR}-K G$ Sorensen) e no caso do grupo $\mathrm{VI}$, durante o tempo de 3 minutos e posteriormente lavados. A retenção dos materiais dos grupos $\|$ a $\mathrm{V}$, completada sua polimerização, foi verificada utilizando-se uma sonda exploradora número 5 (Duflex $\left.{ }^{\circledR}\right)$.

Os dentes dos grupos II a V foram armazenados em água deionizada por 24 horas e os dos grupos VI e VII, em recipiente plástico fechado com 100\% de umidade também por 24 horas. Após este período, o excesso do verniz (grupo VII) da superfície oclusal foi removido com espátula Hollenback (Duflex $®$ ). O restante do verniz foi removido com um cotonete (Johnson \& Johnson ${ }^{\circledR}$ ) umedecido por acetona (Radar $\AA^{-}$- Nova Radar P.Q. \& F. Ltda), de acordo com as recomendações de VAN DORP; TEN CATE ${ }^{122}$ (1992). 


\subsubsection{Ciclagem de $\mathrm{pH}$}

Os dentes dos grupos I a VII foram submetidos a um modelo dinâmico de ciclagens de desmineralização e remineralização similar ao utilizado por FEATHERSTONE et al. ${ }^{29}$ (1986) para obtenção das lesões artificiais de cárie oclusal incipiente.

Todos os dentes foram selados com esmalte de unhas incolor (Colorama ${ }^{\circledR}$ - Ceil) - duas camadas - na superfície vestibular e lingual, com exceção da região dos sulcos e fissuras e, de $1 \mathrm{~mm}$ da margem dos materiais aplicados, sendo esta distância medida com paquímetro (Dentaurum). Posteriormente, foram imersos individualmente em potes plásticos identificados, com $40 \mathrm{ml}$ de solução desmineralizante durante 8 horas e depois, lavados em água deionizada para remover a solução, secos com papel absorvente (Snob Santer $\mathbb{B}$ Fábrica de Papel Santa Terezinha S.A.) e colocados em $20 \mathrm{ml}$ de solução remineralizante por 16 horas, a $37^{\circ} \mathrm{C}$. Os ciclos contínuos de desmineralização e remineralização foram conduzidos por 14 dias. Ambas as soluções eram renovadas diariamente. A solução desmineralizante utilizada foi proposta por JENSEN et al. ${ }^{60}$ (1990) e consiste em um tampão de ácido acético/acetato de potássio 560 mM, cálcio $\left(\mathrm{Ca}^{+2}\right)$ 2,2 mM, fosfato $\left(\mathrm{PO}_{4}{ }^{-3}\right)$ 2,2 mM, com pH ajustado para 4,2. A solução remineralizante foi proposta por FEATHERSTONE et al. ${ }^{29}$ (1986) e continha 1,5 $\mathrm{mmol} / \mathrm{l}$ de $\mathrm{Ca}\left(\mathrm{CaCl}_{2}\right), 0,9 \mathrm{mmol} / \mathrm{l}$ de $\mathrm{PO}_{4}\left(\mathrm{Na}_{2} \mathrm{HPO}_{4}\right)$ e $20 \mathrm{mmol} / \mathrm{l}$ de tampão de cacodilato em pH 7,0 ajustado com $150 \mathrm{mmol} / \mathrm{l}$ de $\mathrm{KCl}$ para simular a força iônica da saliva (em torno de $44 \mathrm{mmol} / \mathrm{l})$. 


\subsubsection{Preparo dos espécimes para análise ao Microscópio de Luz Polarizada} (MLP)

Com a finalidade de avaliar o efeito dos diferentes materiais na lesão de cárie oclusal incipiente formada, em todos os dentes dos sete grupos, os espécimes foram analisados após 14 dias de ciclagem através do MLP. Para tal, os espécimes, presos em blocos de cera de articulação Wilson ${ }^{\circledR}$ (Polidental), foram seccionados longitudinalmente, no sentido vestíbulo-lingual, na região central das fissuras, com o auxílio de um disco diamantado de dupla face 7020 (KG Sorensen), obtendo-se assim, dois fragmentos. Duas secções foram então obtidas da região das fissuras, uma de cada um desses fragmentos, perfazendo um total de 140 secções sendo 20 por grupo, que foram em seguida lixadas com lixa d'água de granulações 320, 400, 600 e 1200 (3M do Brasil) em uma Lixadeira (Struers) refrigeradas com água durante 15 segundos em cada granulação, em um total de 1 minuto de lixação por espécime. Discos de feltro (Buehler) e pasta diamantada com 3 ì e 1 ì de granuleãa tipo S-AROTEC Diamond Polishing Compound - Metadi ® II (Buehler), também foram utilizados durante 1 minuto em uma Politriz (Struers) com a finalidade de dar um polimento final, até obter-se a espessura aproximada de 90 ì m, medido com um micrômetro de precisão (Tesa (B). Após embebição em água durante 36 horas, para o completo preenchimento de espaços no esmalte, as lesões foram visualizadas no microscópio (Axioscop-20), com filtro polarizador e analisador Zeiss e intensidade luminosa adequada para observação das propriedades físicas resultantes da análise do material e lâmpada halógena de $50 \mathrm{~W}$, sendo fotografadas com aparelho fotomicrográfico próprio do microscópio de polarização, utilizando-se 
filmes fotográficos Kodak ® ASA 100 - 35 mm (aumentos 25x e 50x), sendo mantidos constantes a intensidade luminosa e o tempo de exposição para todas as lamelas de esmalte.

Vale ressaltar que, quando o esmalte sadio ou desmineralizado é observado em luz polarizada, tanto a parte orgânica quanto a inorgânica são birrefringentes, e essa birrefringência está normalmente relacionada com o longo eixo dos prismas. Em seu interior, tanto os cristais de apatita quanto os espaços existentes entre eles determinam a birrefringência, sendo os cristais responsáveis pela birrefringência negativa e as partes desmineralizadas pela positiva. As partes do esmalte mais intensamente mineralizadas aparecem azuis ou verde-azuladas (birrefringência negativa) e as áreas menos mineralizadas de cor amarela (birrefringência positiva). Por outro lado, se houver quantidade semelhante de substâncias negativa e positivamente birrefringentes, as cores se anulam, notandose uma área escura denominada pseudo-isotropismo (PIMENTA $\left.{ }^{88}, 1991\right)$.

4.2.5.1 Avaliação das alterações microestruturais das lesões artificiais de cárie oclusal

Para avaliação quantitativa das lesões artificiais de cárie, foi acoplada à máquina fotográfica do microscópio durante as tomadas fotográficas, um dispositivo óptico com barra calibrada, de $23 \mathrm{~mm}$ de comprimento, de forma que nas fotografias tal escala era representada. Utilizando-se a fórmula:

$$
\mu \mathrm{m}=\frac{2000}{\text { Aocular } \times \text { Aobjetiva }}
$$


sendo Aocular o aumento da lente ocular e Aobjetiva o aumento da lente objetiva, foi possível calcular a micragem da escala nas fotografias padronizadas, facilitando a leitura das medidas. A profundidade $(\mu \mathrm{m})$ da lesão foi avaliada nas fotomicrografias padronizadas (tamanho $10 \times 15 \mathrm{~cm}$ ), utilizando-se uma régua com frações de milímetros (Kawasa ${ }^{\circledR}$ ), tomando-se como base a área de maior profundidade da lesão através de medições transversais, perpendiculares àsuperfície do esmalte, em seis pontos padronizados e eqüidistantes entre si, ao longo do aspecto interno do corpo da lesão, nas paredes laterais da fissura, registrando-se a distância que ia da superfície externa do esmalte em direção à região mais interna, com maior grau de desmineralização, conforme ilustrado na Fig. 2. Considerando-se que $23 \mathrm{~mm}$ correspondiam a 4 ì m, valor este obtido a partir da fórmula citada, utilizandose regra matemática de três, era possível calcular a medida de profundidade (ì m) em cada uma das seis medições. As médias das seis medidas obtidas das 20 secções por grupo foram calculadas e registradas em planilha e, posteriormente, obtida a média total destas medidas em cada grupo para comparação entre os mesmos de acordo com metodologia proposta por SEPPÄ; FORSS ${ }^{102}$ (1991).

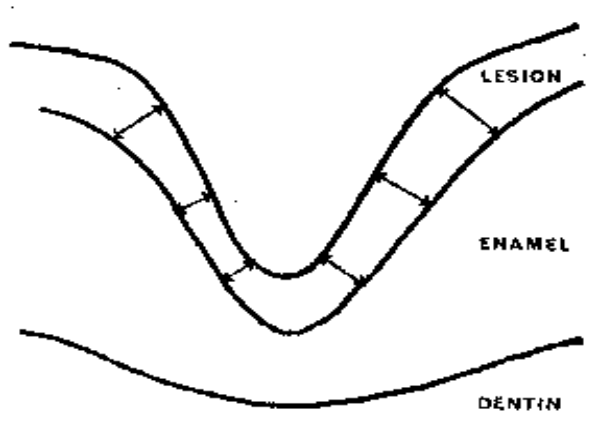

Figura 2 - Diagrama descrevendo a técnica de mensuração. As setas mostram os pontos nos quais foram realizadas as medidas de profundidade na área da lesão (lesion = lesão; enamel = esmalte; dentin = dentina. Adaptado de SEPPÄ, L.; FORSS, H. ${ }^{102}$ ). 
A área da lesão $\left(\mu \mathrm{m}^{2}\right)$ foi calculada nas fotomicrografias padronizadas, adaptando-se sobre a fotografia um retículo quadriculado xerocado em folha de transparência, englobando toda a região da lesão. Tomando-se como base o mesmo dispositivo óptico com barra calibrada de $23 \mathrm{~mm}$ de comprimento, através da fórmula já apresentada, foi calculado que quatro quadrados do retículo correspondiam a 4 ì m, assim, aárea de cada lesão pode ser obtida multiplicando -se a base pela altura.

Durante a análise quantitativa, a examinadora executou as medições sem ter conhecimento prévio a qual dos grupos pertencia cada amostra, sendo, portanto, um estudo cego.

\subsubsection{Análise estatística}

As médias das seis medidas obtidas das secções de cada dente foram calculadas nos sete grupos e comparadas estatisticamente através do teste nãoparamétrico de Kruskal-Wallis para avaliação dos fatores profundidade e área da lesão. A fim de elucidar diferenças significativas, foi utilizado o teste de Comparações Múltiplas de Dunn. O nível de significância adotado foi fixado em 5\% (SIEGEL $\left.{ }^{106}, 1975\right)$. 
5 RESULTADOS 


\section{RESULTADOS}

A média e o desvio-padrão relativos à profundidade e à área da lesão obtidos na análise microscópica das lesões de cárie após o período de 14 dias de ciclagem nas secções dos dentes dos sete grupos estudados estão apresentadas no APÊNDICE A (Quadros 1 e 2). Durante o processo de preparo das amostras para a análise ao microscópio, algumas secções foram danificadas, sendo então desprezadas para efeito da avaliação microestrutural. Assim, ao grupo I e V corresponderam 12 secções; ao grupo I e III, 11 secções; ao grupo IV, 14 secções; ao grupo VI, 16 secções e ao grupo VII, 15 secções.

A Prova de Kruskal-Wallis desses dados (Quadros 3 e 4, APÊNDICE B) mostrou diferença estatisticamente significante ( á=0,1\%) tanto a $\mathrm{n}$ ível de profundidade quanto de área da lesão.

Em decorrência da significância estatística desses fatores, empregouse a técnica de Análise de Comparações Múltiplas de Dunn para identificação das diferenças mínimas significativas entre os grupos (Quadros 5 e 6, APÊNDICE C). Os resultados dessa análise mostraram diferenças significativas ( á=5\%) entre os tratamentos dos grupos V, VI e VII em relação ao Gl (controle) e sem diferença estatística significante entre este e os grupos II, III e IV quanto à profundidade da lesão. Com relação à área, as médias obtidas nos tratamentos III, IV, V, VI e VII foram significativamente menores (á=5\%) que a do Gl e sem diferença estatística significante entre este grupo e o Gll. 
As médias de profundidade da lesão dos tratamentos estão apresentadas na Tabela 1 e na Tabela 2 (p. 59), em relação àárea da lesão.

Tabela 1 - Média de distribuição do aspecto microscópico das lesões artificiais de cárie quanto àsua profundidade $(\mu \mathrm{m})$ nas amostras dos 7 grupos estudados

\section{Tratamentos}

\begin{tabular}{ccc} 
& Médias $(\overline{\mathbf{X}})$ & Desvio-padrão (s) \\
\hline GI & $5,81^{\mathrm{a}}$ & 2,29 \\
GII & $3,67^{\mathrm{a}}$ & 1,19 \\
GIII & $2,10^{\mathrm{a}}$ & 1,25 \\
GIV & $3,69^{\mathrm{a}}$ & 3,72 \\
GV & $0,89^{\mathrm{b}}$ & 1,03 \\
GVI & $0,61^{\mathrm{b}}$ & 0,69 \\
GVII & $0,29^{\mathrm{b}}$ & 0,44 \\
\hline *as médias seguidas por letras distintas diferem entre si (á=0,1\%) quando comparadas na vertical
\end{tabular}

Observando-se na Tabela 1 as comparações entre as médias de profundidade de lesão, nota-se menores valores de profundidade da lesão em ordem crescente para os tratamentos Duraflur ${ }^{\circledR}(\mathrm{GVII})$, Safluoride $\AA(\mathrm{GVI})$ e Vitremer ${ }^{\circledR}(G V)$, que não diferiram estatisticamente entre si, seguidos dos maiores valores de profundidade dos materiais Ketac Molar $\AA$ (GIV), Delton ${ }^{\circledR}$ (GII) e Fluroshield $\circledast$ (GIII), que não diferiram estatisticamente do Controle (GI). 
Tabela 2 - Média de distribuição do aspecto microscópico das lesões artificiais de cárie quanto àsua área $\left(\mu \mathrm{m}^{2}\right)$ nas amostras dos 7 grupos estudados

\section{Tratamentos}

\begin{tabular}{ccc} 
& Médias $(\overline{\mathbf{X}})$ & Desvio-padrão (s) \\
\hline GI & $25,04^{\mathrm{a}}$ & 9,49 \\
GII & $16,39^{\mathrm{a}}$ & 8,32 \\
GIII & $4,91^{\mathrm{b}}$ & 4,28 \\
GIV & $3,69^{\mathrm{b}}$ & 3,72 \\
GV & $0,81^{\mathrm{b}}$ & 1,04 \\
GVI & $2,86^{\mathrm{b}}$ & 3,81 \\
GVII & $1,78^{\mathrm{b}}$ & 5,04
\end{tabular}

* as médias seguidas por letras distintas diferem entre si (á=0,1\%) quando comparadas na vertical

Analisando as médias referentes à área de lesão de cada tratamento dispostas na Tabela 2, verifica-se valores menores em ordem crescente para os tratamentos Vitremer ${ }^{\circledR}(\mathrm{GV})$, Duraflur ${ }^{\circledR}(\mathrm{GVII})$, Safluoride $\AA(\mathrm{GVI})$, Ketac Molar ${ }^{\circledR}$ (GIV) e Fluroshield ${ }^{\circledR}$ (GIII), que não apresentaram diferenças significativas entre si e o Delton ${ }^{\circledR}(G I I)$, que não diferiu em relação ao Controle $(G)$, estes dois grupos apresentando os maiores valores.

Sintetizando os resultados obtidos neste estudo com relação à profundidade e à área da lesão, para melhor visualização os mesmos foram dispostos em gráficos representados nas Fig. 3 e 4 (p. 60).

Já as Fig. 5 a 11 (p. 61 a 67) ilustram os aspectos microscópicos da lesão artificial de cárie oclusal nos grupos estudados (GI a GVII) e as Fig. 12 a 16 (p. 68 a 72), áreas de remineralização da lesão observadas apenas em espécimes dos grupos III a VII. 


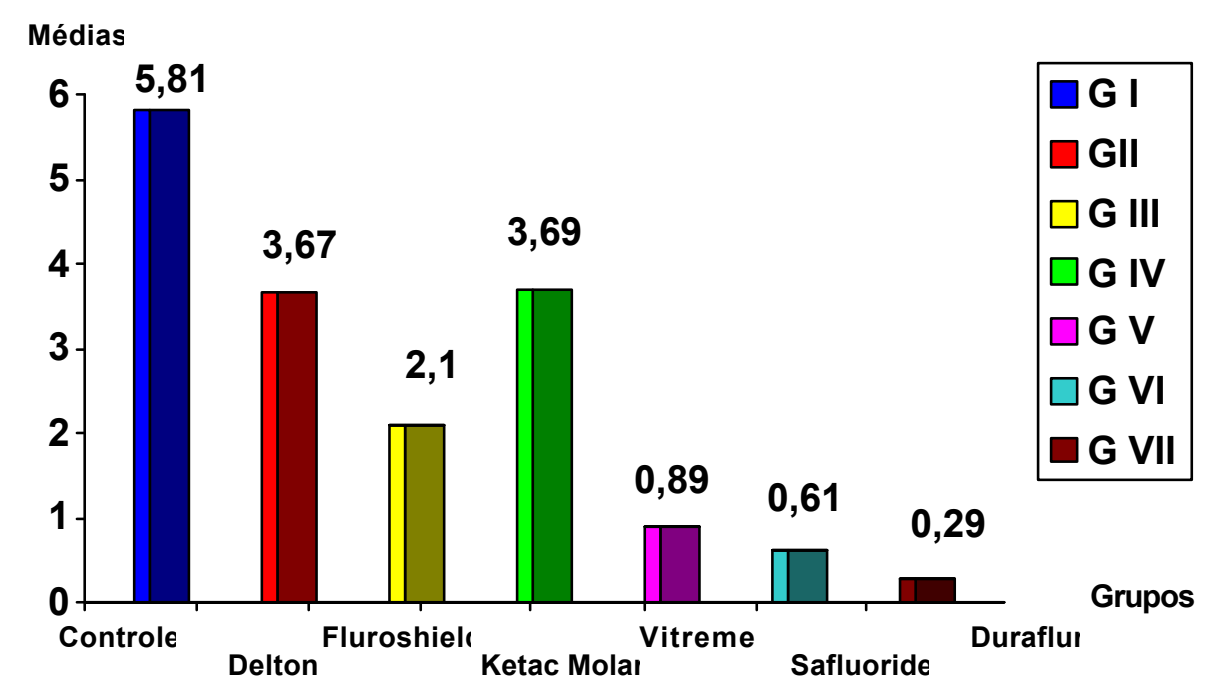

Figura 3 - Média de profundidade da lesão $(\mu \mathrm{m})$ nas amostras dos 7 grupos estudados.

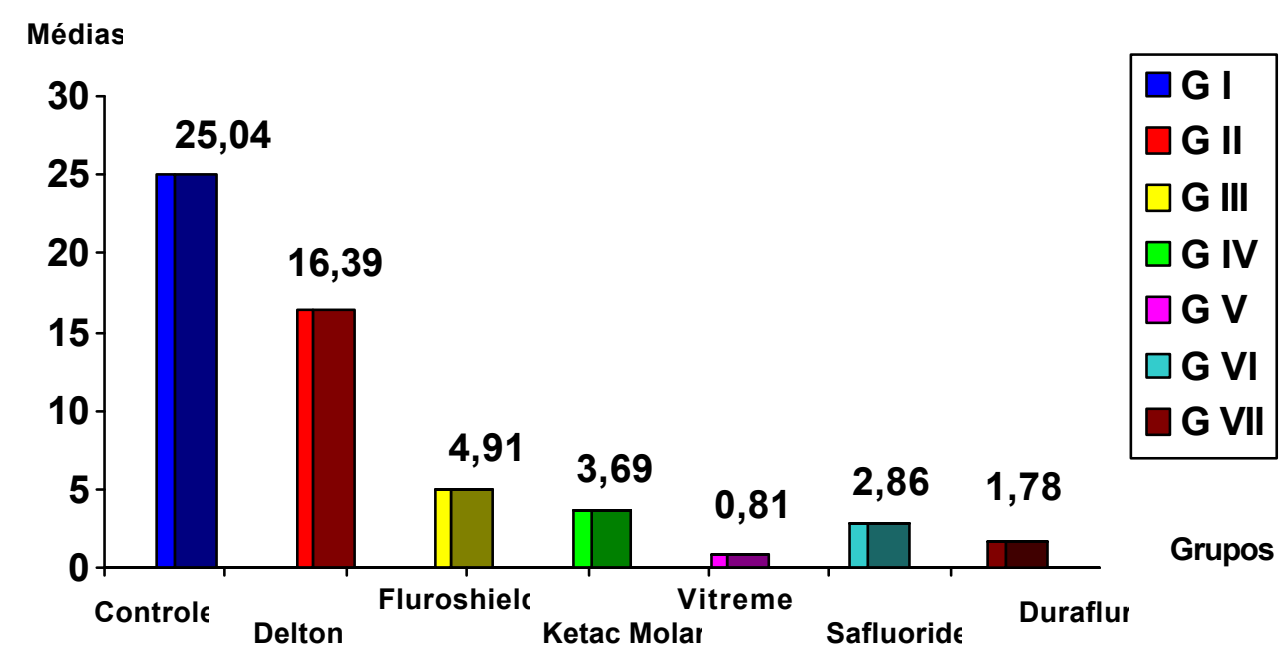

Figura 4 - Média de área da lesão $\left(\mu \mathrm{m}^{2}\right)$ nas amostras dos 7 grupos estudados. 


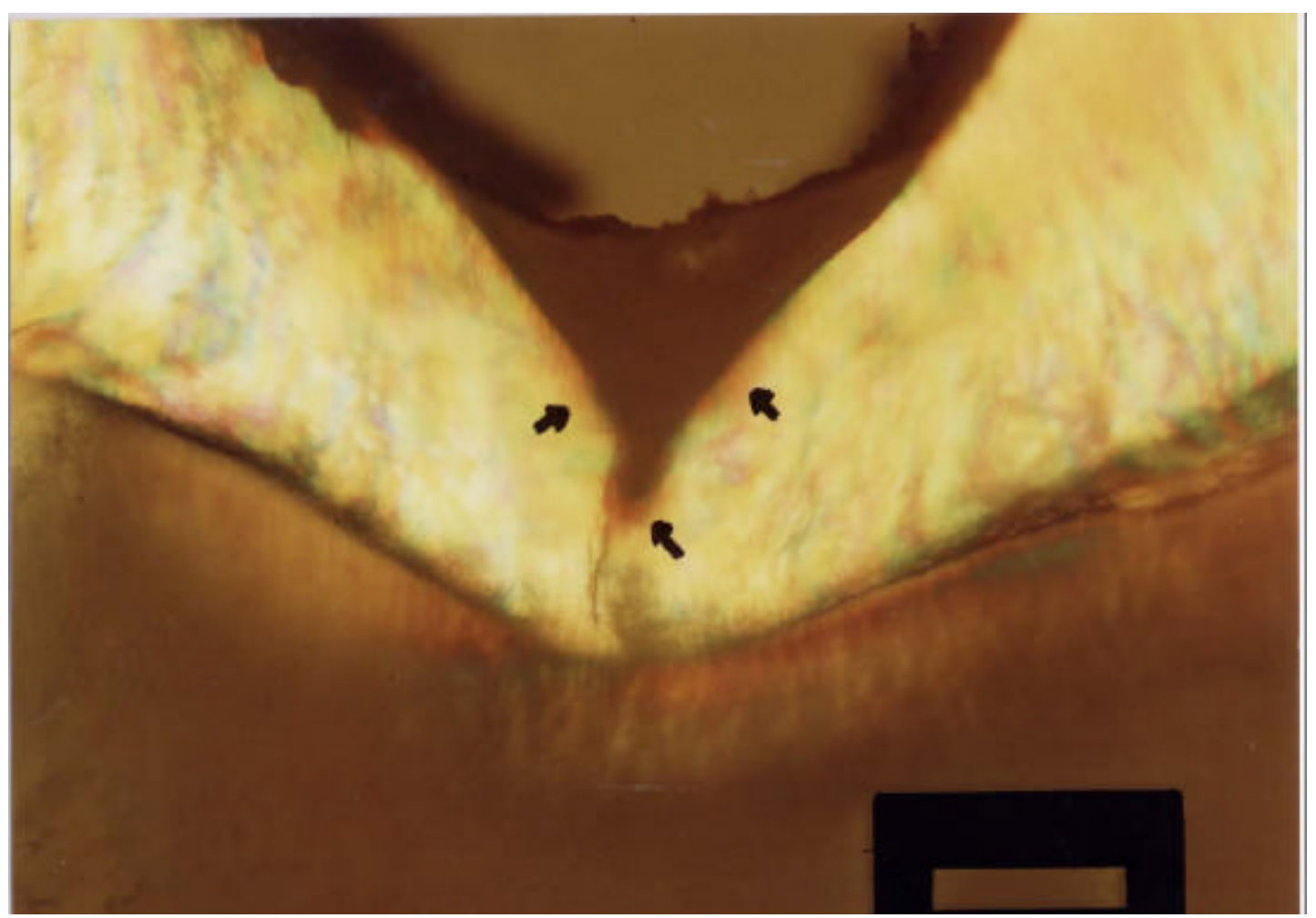

Figura 5 - Fotomicrografia em secção longitudinal de uma lesão de cárie artificial na fissura de um espécime do Gl. No detalhe observa-se a área de birrefringência positiva laranja (setas). Notar no canto inferior direito dispositivo para a análise quantitativa. Aumento 50x. 


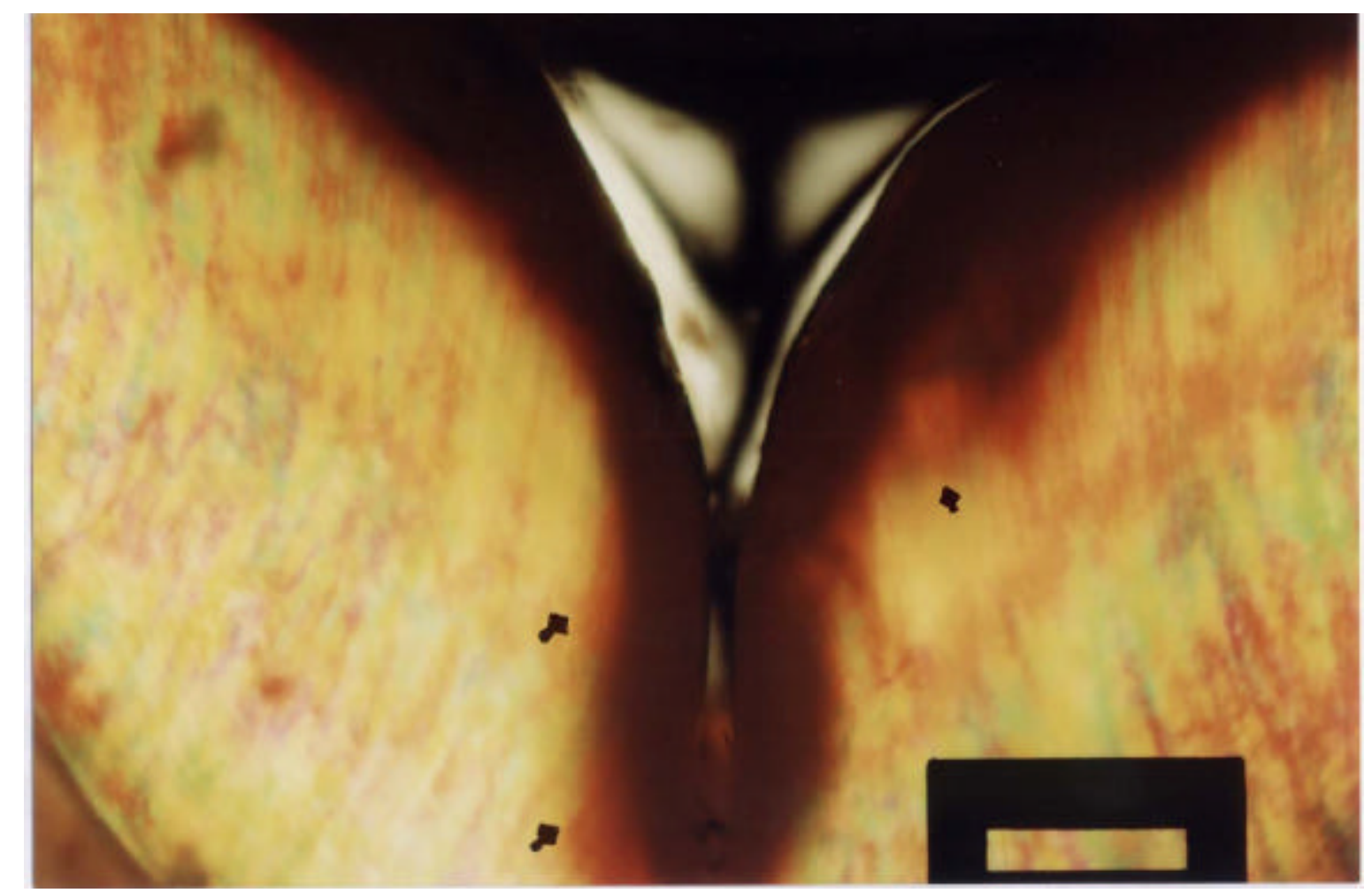

Figura 6 - Fotomicrografia em secção longitudinal de uma lesão de cárie artificial na fissura de um espécime do GII (setas). Aumento 50x. 


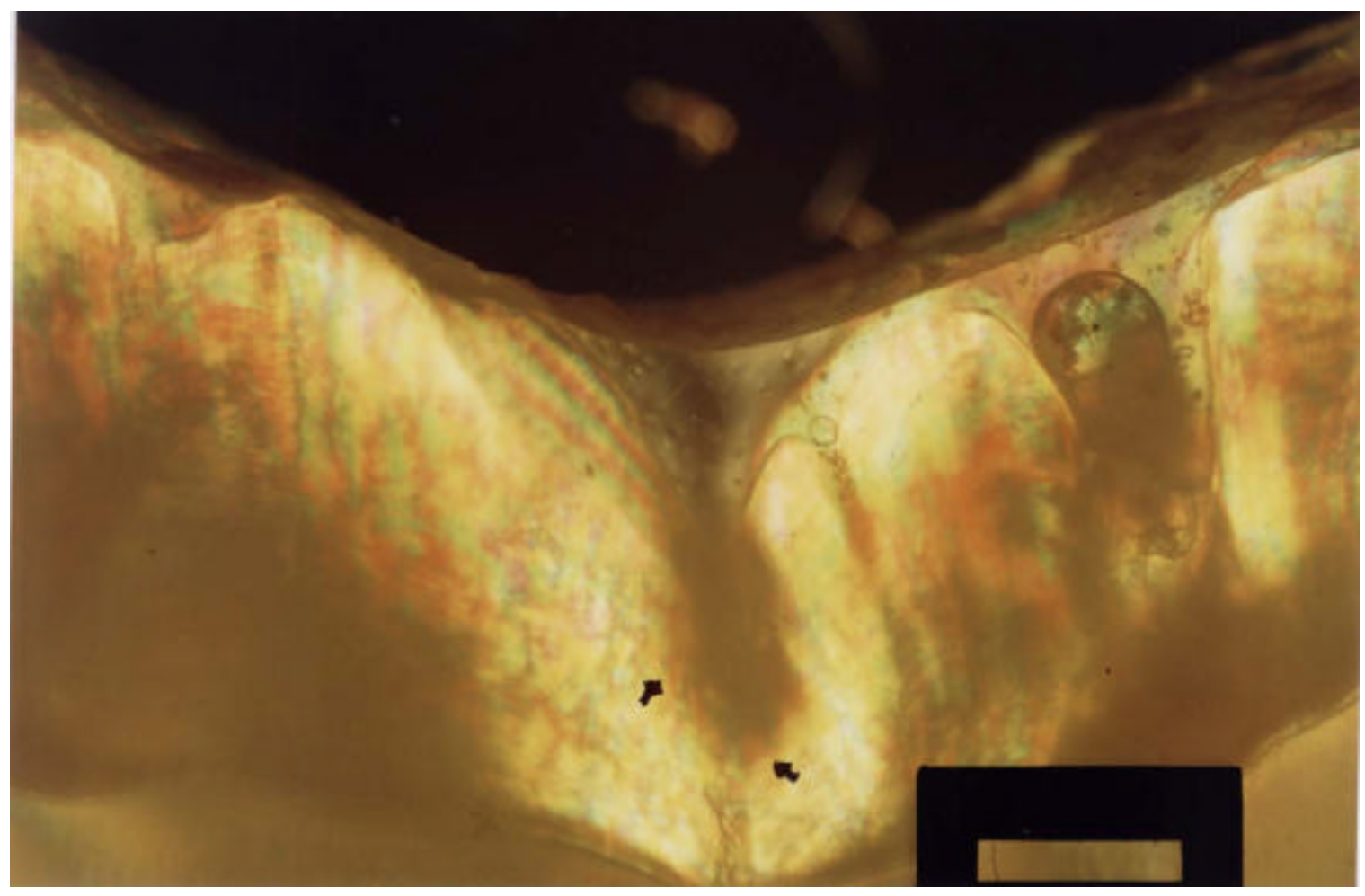

Figura 7 - Fotomicrografia em secção longitudinal de uma lesão de cárie artificial na fissura de um espécime do GIII (setas). Aumento 50x. 


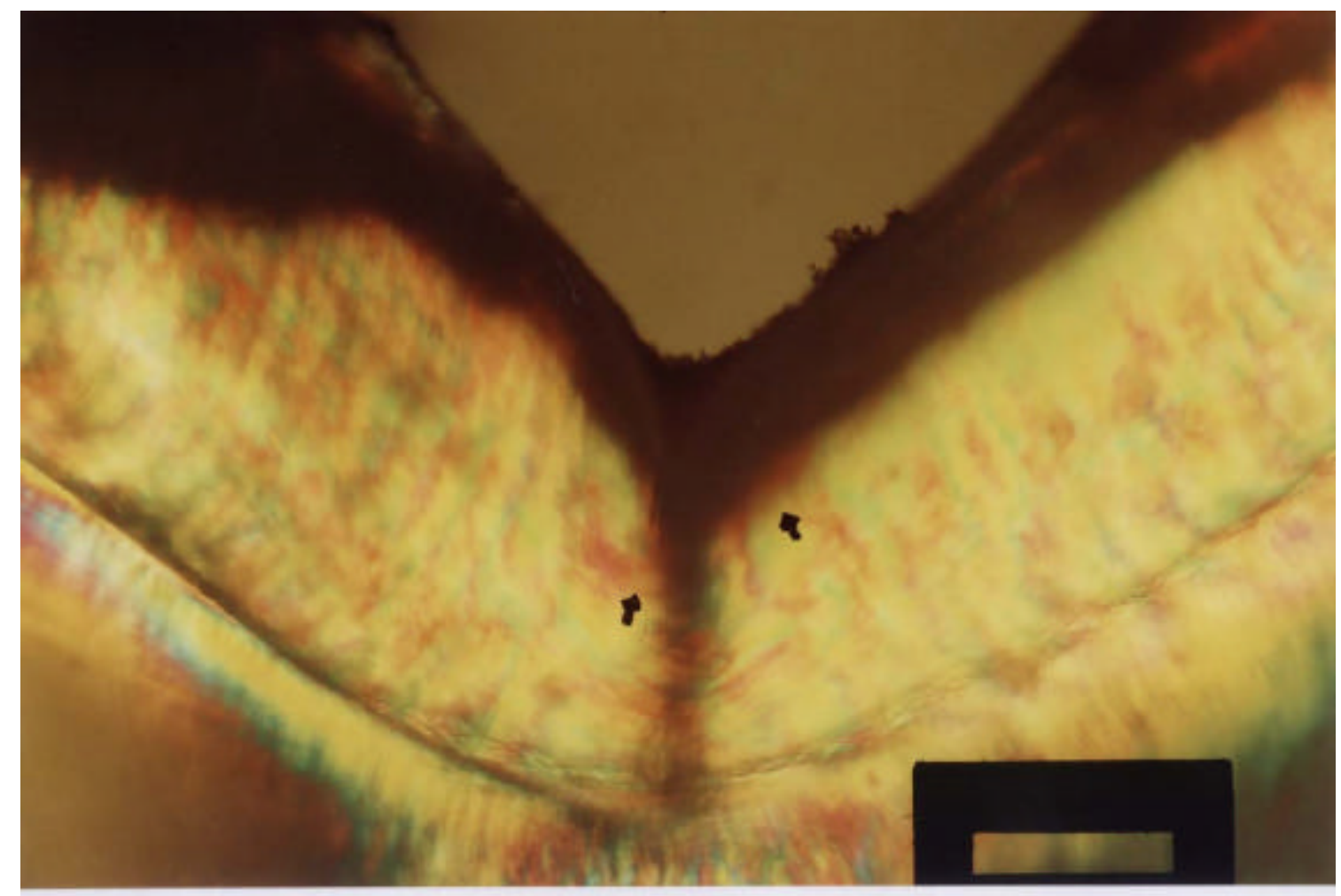

Figura 8 - Fotomicrografia em secção longitudinal de uma lesão de cárie artificial na fissura de um espécime do GIV (setas). Aumento 50x. 


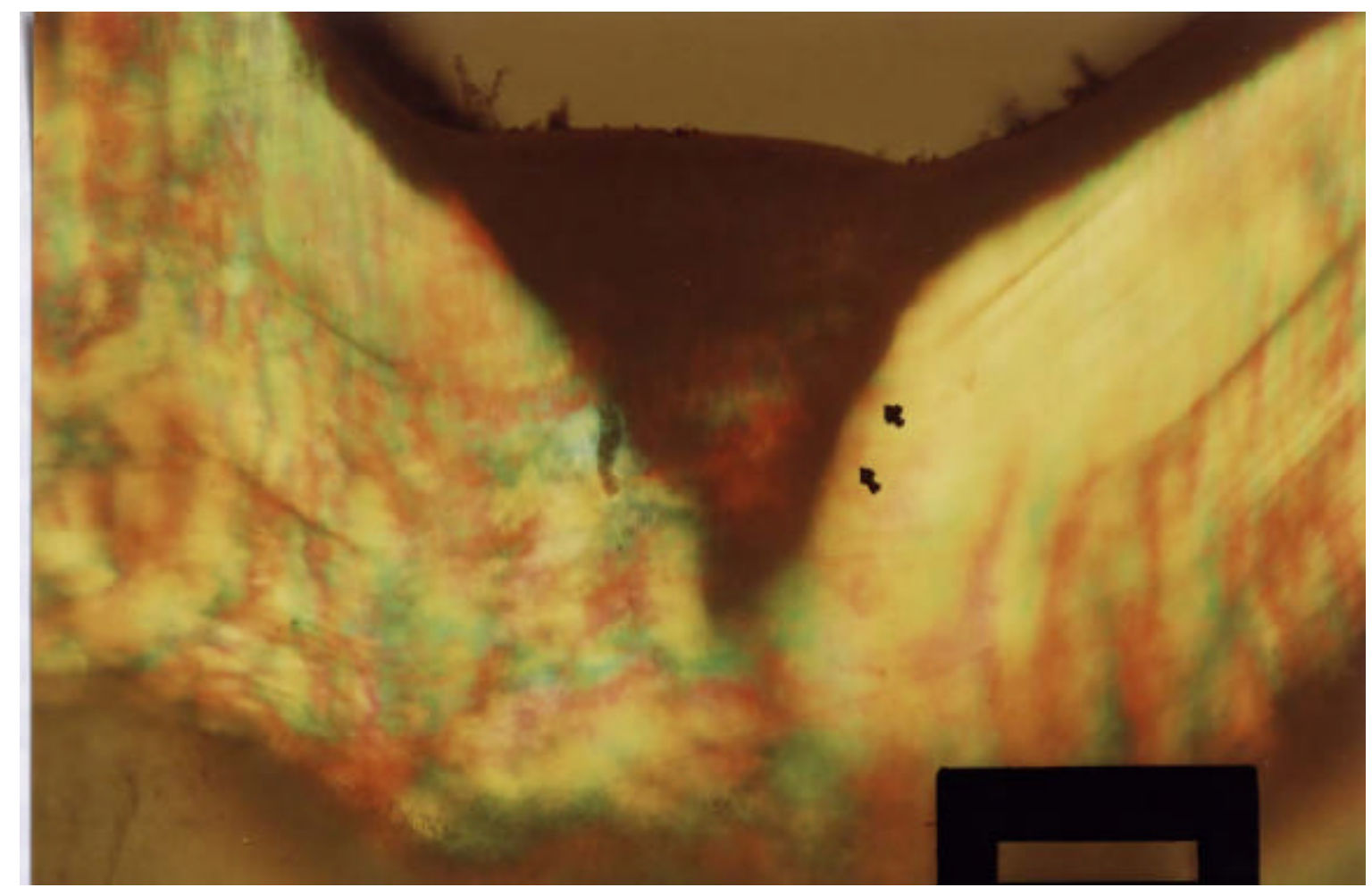

Figura 9 - Fotomicrografia em secção longitudinal de uma lesão de cárie artificial na fissura de um espécime do GV (setas). Aumento 50x. 


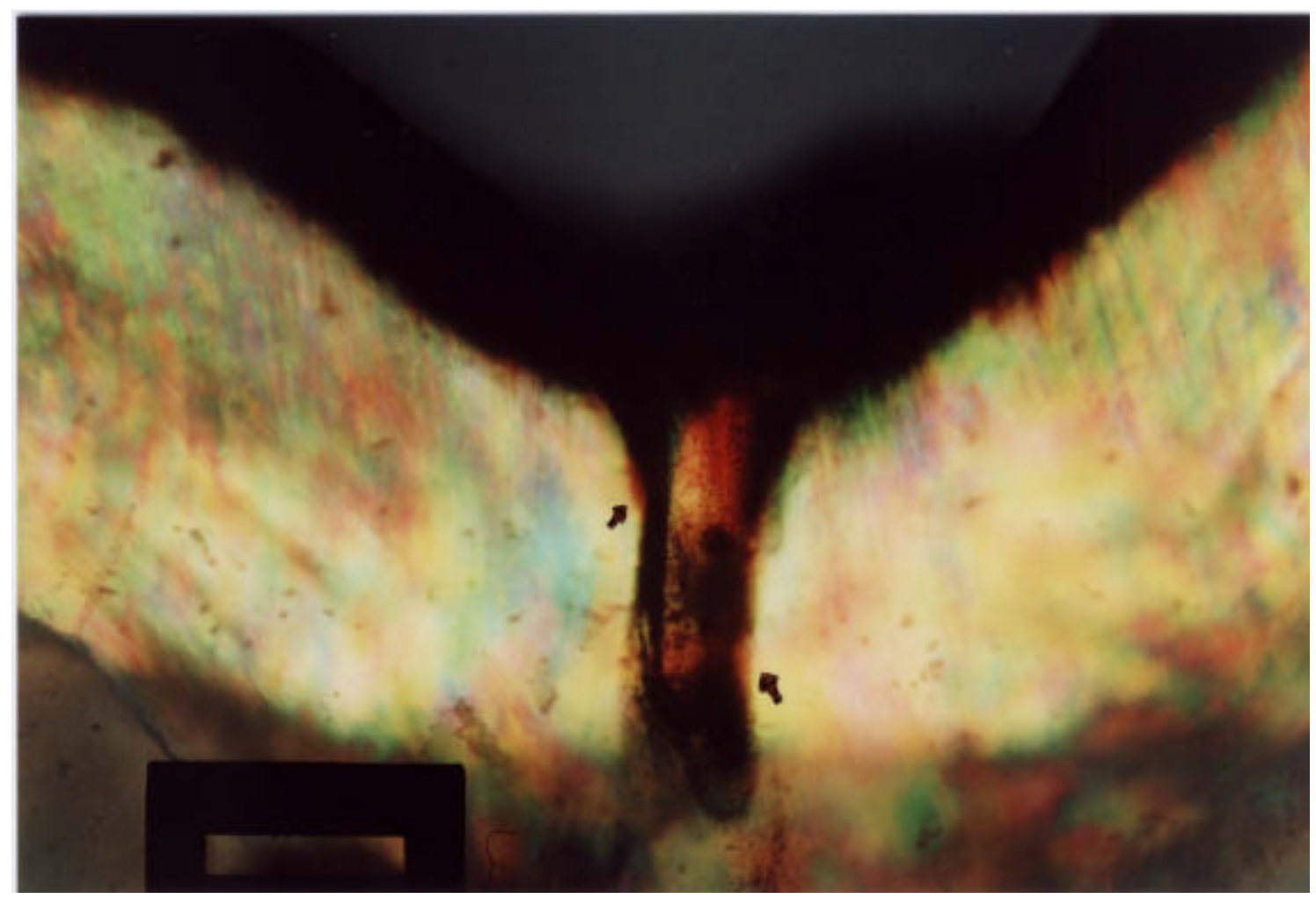

Figura 10 - Fotomicrografia em secção longitudinal de uma lesão de cárie artificial na fissura de um espécime do GVI (setas). Aumento 50x. 


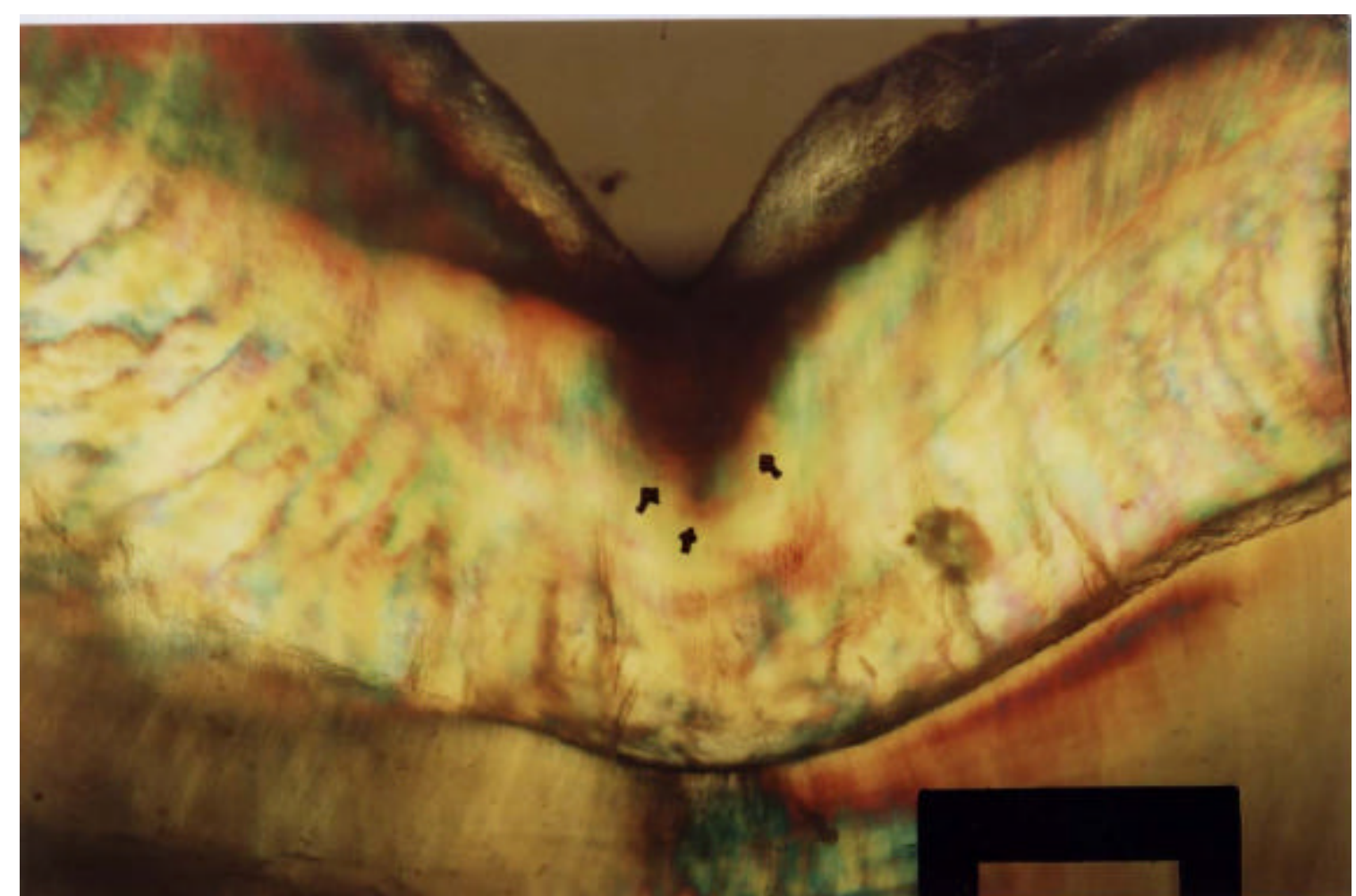

Figura 11 - Fotomicrografia em secção longitudinal de uma lesão de cárie artificial na fissura de um espécime do GVII (setas). Aumento 50x. 


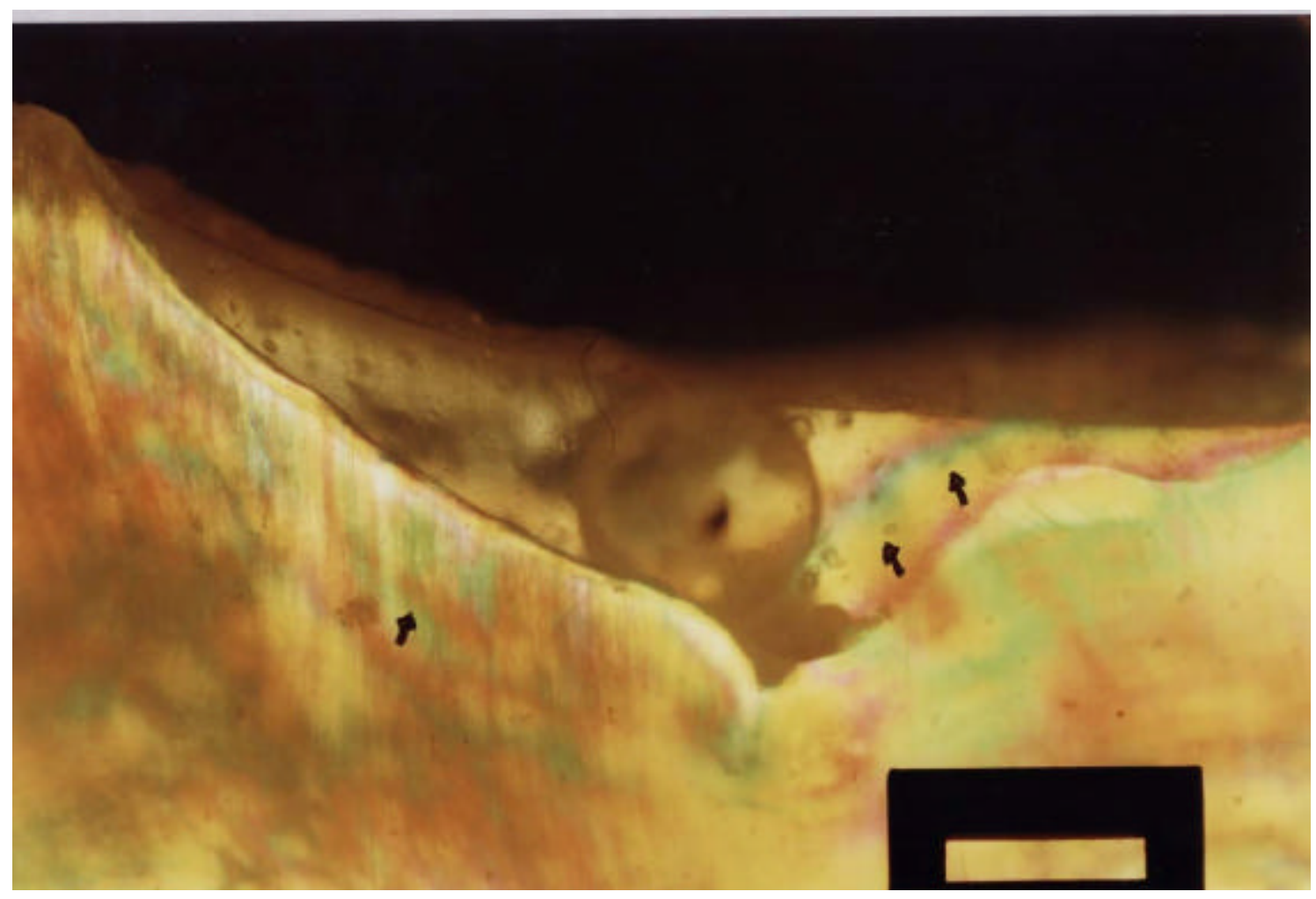

Figura 12 - Fotomicrografia em secção longitudinal mostrando a remineralização de uma lesão de cárie artificial na fissura de um espécime do Glll. No destaque nota-se a área de birrefringência negativa azul-esverdeada (setas) indicativa de remineralização de lesão de cárie. Aumento 50x. 


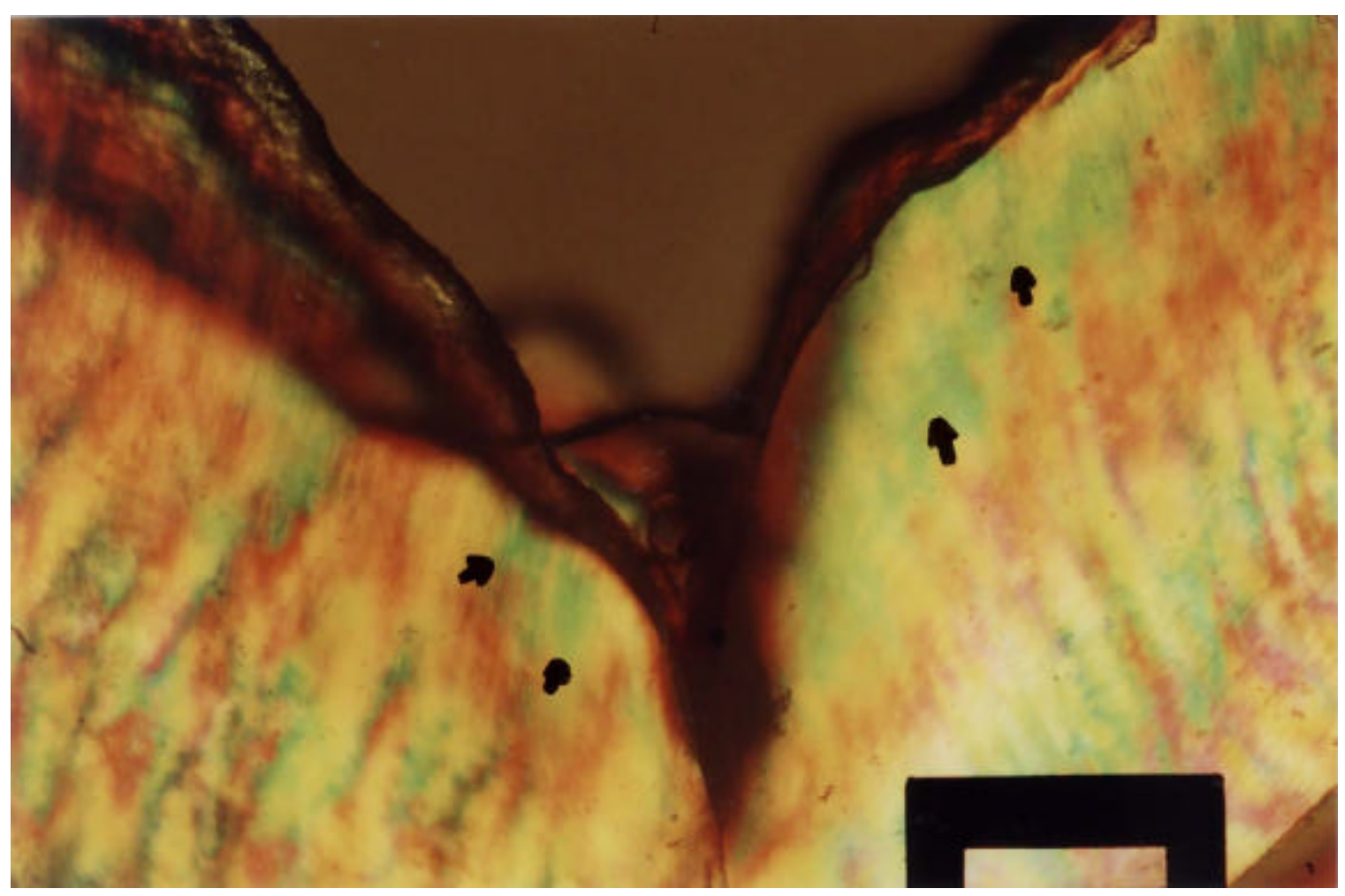

Figura 13 - Fotomicrografia em secção longitudinal mostrando a remineralização de uma lesão de cárie artificial na fissura de um espécime do GIV (setas). Aumento 50x. 


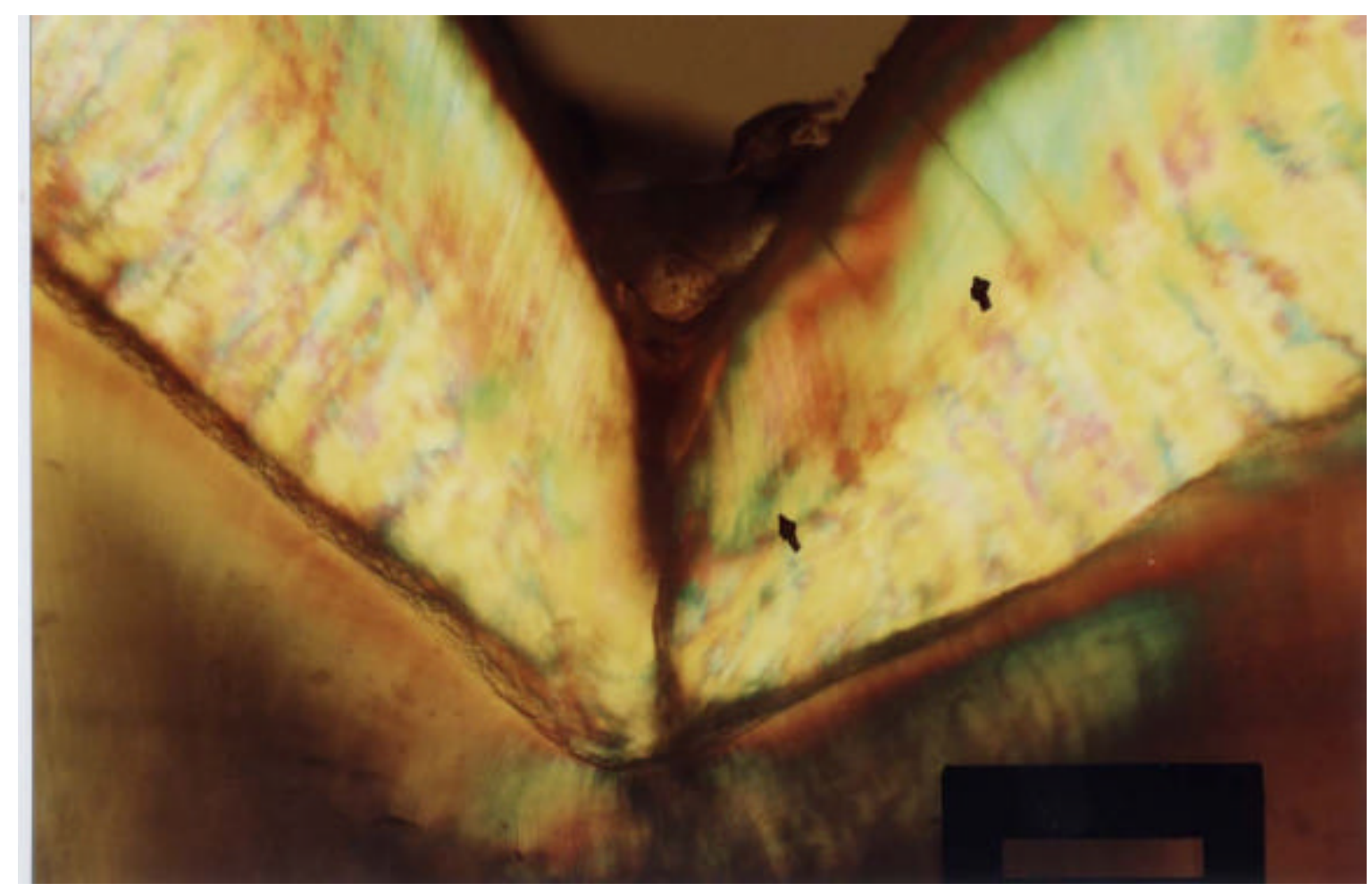

Figura 14 - Fotomicrografia em secção longitudinal mostrando a remineralização de uma lesão de cárie artificial na fissura de um espécime do GV (setas). Aumento 50x. 


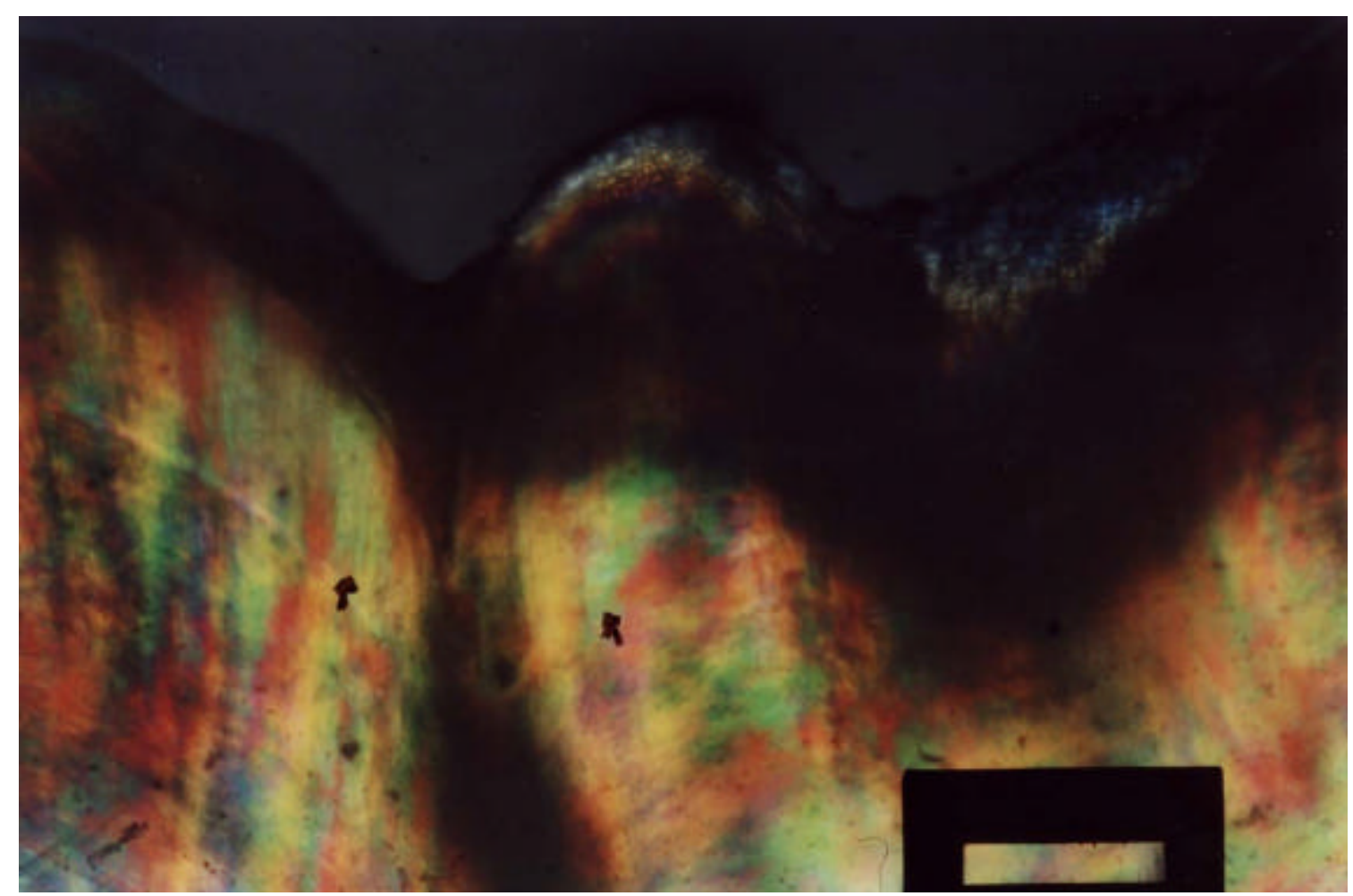

Figura 15 - Fotomicrografia em secção longitudinal mostrando a remineralização de uma lesão de cárie artificial na fissura de um espécime do GVI (setas). Aumento 50x. 


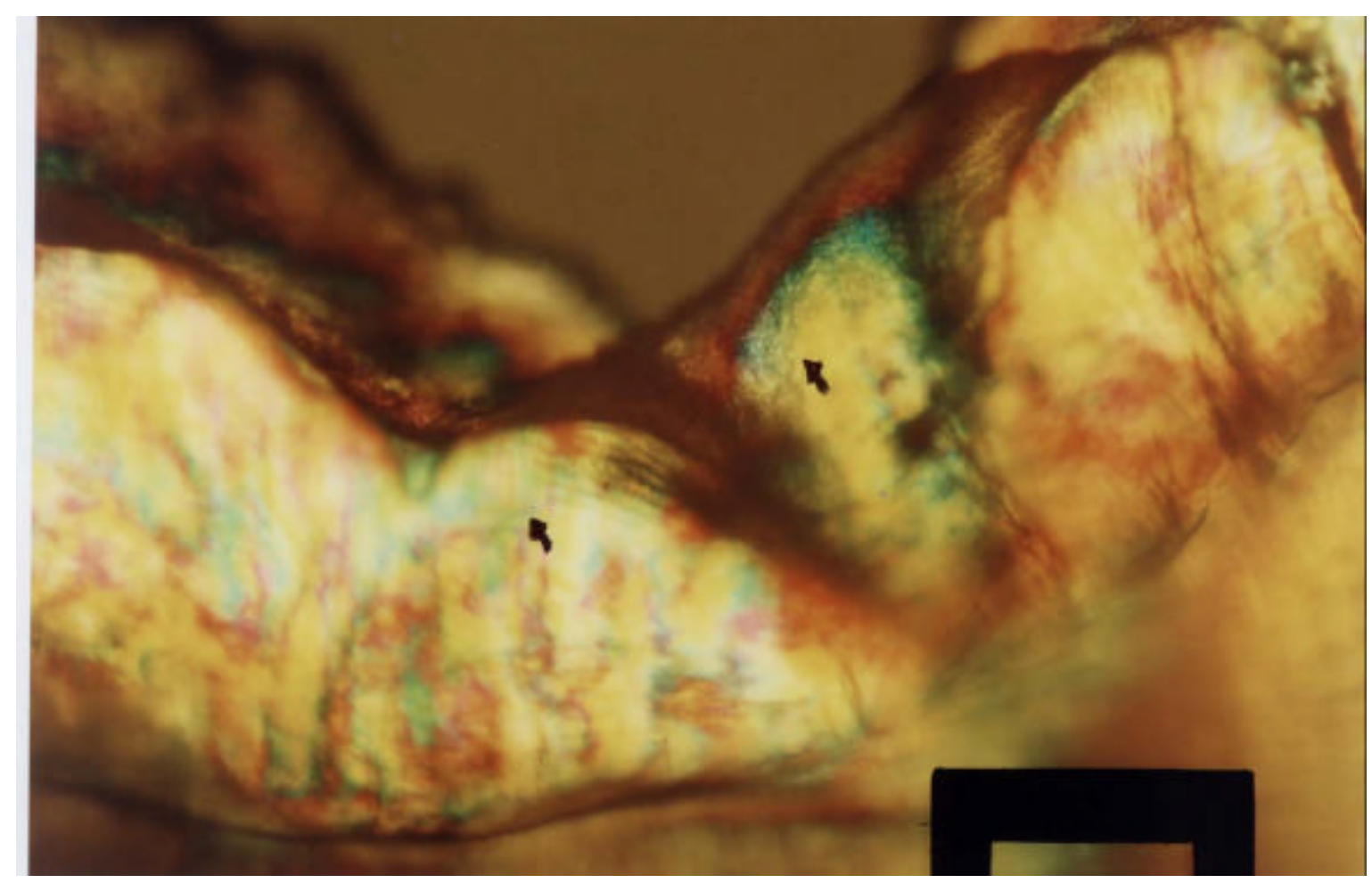

Figura 16 - Fotomicrografia em secção longitudinal mostrando a remineralização de uma lesão de cárie artificial na fissura de um espécime do GVII (setas). Aumento 50x. 


\section{DISCUSSÃO}

Este capítulo será subdividido em duas partes. Na primeira serão discutidos os resultados em relação ao potencial cariostático dos materiais utilizados para selamento de sulcos e fissuras - selantes resinosos e cimentos ionoméricos - e na segunda, os obtidos com o verniz fluoretado e com a solução de DFP, tanto em relação àprofundidade quanto àárea da lesão.

\subsection{Avaliação do potencial cariostático dos selantes resinosos e dos cimentos ionoméricos utilizados para selamento de sulcos e fissuras}

Dentre os materiais fluoretados testados neste estudo, observou-se os melhores resultados com o CIV modificado Vitremer ${ }^{\circledR}$ em ambos os fatores testados - profundidade e área de lesão $\left(0,89 \mu \mathrm{m}\right.$ e $\left.0,81 \mu \mathrm{m}^{2}\right)$ - , enquanto o CIV de presa rápida Ketac Molar $\AA$, o pior em relação àprofundidade da lesão $(3,69 \mu \mathrm{m})$ e 0 selante resinoso Fluroshield ${ }^{\circledR}$, em relação àárea da lesão $\left(4,91 \mu \mathrm{m}^{2}\right)$. Já o selante resinoso sem flúor Delton ${ }^{\circledR}$ não diferiu estatisticamente do controle quanto à profundidade e área de lesão $\left(3,67 \mu \mathrm{m}\right.$ e 16,39 $\mu \mathrm{m}^{2}$ e 5, $81 \mu \mathrm{m}$ e 25,04 $\mu \mathrm{m}^{2}$, respectivamente), conforme demonstrado nas Tabelas 1 e 2 (p. 58 e 59) e nas Figuras 3 e 4 (p. 60). As Figuras 5 a 8 (p. 61 a 64) obtidas do MLP demonstram visualmente, de forma comparativa, exemplos de lesão de cárie observadas nos grupos controle, dos selantes resinosos Delton ${ }^{\circledR}$ e Fluroshield $\AA$ e, no de CIV de presa rápida Ketac Molar ${ }^{\circledR}$, e as Figuras 12 a 14 (p. 68 a 70), exemplos de remineralização obtidos em amostras do grupo do selante resinoso fluoretado 
Fluroshield $\AA$ e nos de CIV de presa rápida Ketac Molar ${ }^{\circledR}$ e modificado por resina Vitremer ${ }^{\circledR}$.

Estes achados discordam dos encontrados por GOEPFERD; OLBERDING 45 (1989), utilizando um selante resinoso convencional sem flúor fotopolimerizável, com metodologia diferente da empregada neste trabalho, observaram que o mesmo impediu a progressão de lesões de cárie artificial de mancha branca em superfície lisa quando estas foram re-expostas ao meio ácido, em comparação ao grupo controle sem selamento, que apresentou um aumento de profundidade de $51 \%$.

Por outro lado, estes resultados estão de acordo com os obtidos por DECICO et al. ${ }^{22}$ (1994) que empregaram testes de microdureza e com os de JENSEN et al. ${ }^{60}$ (1990), HICKS; FLAITZ ${ }^{49}$ (1998) e HICKS; FLAITZ; GARCIAGODOY 50 (2000), que ao compararem um selante fluoretado com um não fluoretado, observaram também ao MLP como neste estudo, uma melhor performance do primeiro com relação àinibição da progressão da lesão de cárie. $E$ com o trabalho in situ de TOSTES AMARAL ${ }^{119}$ (1999) que, em testes de microdureza Knoop do esmalte oclusal adjacente aos sulcos e fissuras selados com CIV de presa rápida Fuji IX $\AA$, observou a recuperação da dureza (remineralização) desta região, apenas com este material, quando comparado com o selante resinoso Delton ${ }^{\circledR}$, assim como no estudo in vitro ao MLP de HICKS; FLAITZ ${ }^{48}$ (1992), que também encontraram melhor proteção do esmalte oclusal adjacente ao CIV Ketac Fil ® utilizado como selante, quando comparado com o selante resinoso sem flúor Prisma Shield $\AA$, apesar dos materiais serem diferentes e de algumas metodologias, também, o que dificulta maiores comparações. 
Sabe-se que a biodisponibilidade do flúor incorporado ao material restaurador ou através de outras medidas preventivas é de considerável importância no início e progressão da lesão de cárie. A porcentagem de flúor presente nos CIV pode variar de 10 a $23 \%$, enquanto que nos selantes resinosos fluoretados, é de cerca de $2 \%$ segundo HICKS; FLAITZ ${ }^{48}$ (1992).

A presença constante de flúor no meio bucal confere aos CIV propriedades anticariogênicas e cariostáticas, promovendo uma inversão no processo de desmineralização e favorecendo a remineralização do esmalte. O flúor liberado pelo CIV pode incorporar-se aos tecidos mineralizados, tornando-os mais resistentes aos ciclos de desmineralização, além de ter a capacidade de remineralizar a estrutura dentária desmineralizada adjacente ao material e adquirir flúor de distintas fontes (recarregamento), funcionando como reservatório do íon, liberando-o constantemente e mantendo a longo prazo suas propriedades cariostáticas $^{37,102,116,131}$.

De acordo com HICKS; FLAITZ ${ }^{48}$ (1992), o flúor liberado destes materiais pode influenciar o início e a progressão da lesão de cárie através de vários mecanismos. Esta incorporação de flúor no esmalte adjacente resulta na redução de sua solubilidade. No caso específico dos selantes resinosos fluoretados, a concentração de flúor no esmalte circundante a estes materiais é de 3500 ppm e 1700 ppm à distância de $10 \mu \mathrm{m}$ e $60 \mu \mathrm{m}$ da superfície do esmalte, respectivamente, enquanto no controle é de aproximadamente 700 ppm e 200 ppm, respectivamente. O nível aumentado de flúor no esmalte sadio adjacente e subjacente ao material fluoretado pode reduzir a solubilidade do esmalte em ácidos orgânicos e resultar em uma maior resistência à formação da lesão de cárie, além de maior resistência à progressão da mesma. 
Após a inserção do selamento tanto com CIV quanto com selante resinoso fluoretado nos sulcos e fissuras, este material fornece uma alta liberação de flúor nos primeiros dois dias (8,9 a 11,4 ppm), diminuindo lentamente esta liberação após uma semana $(0,41$ ppm) e mantendo-se constante por períodos de até 12 meses no caso dos selantes resinosos e de 30 meses para o CIV, de acordo $\infty \mathrm{m}$ COOLEY et al. ${ }^{18}$ (1990), SEPPÄ; FORSS ${ }^{102}$ (1991), YIP ${ }^{131}$ (1996), GARCIAGODOY et al. ${ }^{39}$ (1997) e GAO; SMALES; LAM ${ }^{37}$ (1997).

PIMENTA; PAVARINI; TÁRZIA ${ }^{89}$ (1991) observaram em seu estudo in vitro que a liberação de íon flúor do Fluroshield ${ }^{\circledR}$ é insignificante, como valor terapêutico, sendo de 1 ppm nas primeiras 24 horas, chegando após este período a zero. Os mesmos autores em 1992, observaram que após a remoção deste selante da superfície dentária proximal, com subseqüente exposição da mesma ao ataque ácido, este produto não aumentou a proteção desta superfície, assim os autores consideraram que o efeito deste material seria restrito à sua ação mecânica, o mesmo resultado encontrado com o selante resinoso sem flúor Prismashield $₫$ (PIMENTA; TÁRZIA; PAVARINI $\left.{ }^{90}, 1992\right)$.

Por outro lado, SEPPÄ; FORSS ${ }^{102}$ (1991) observaram ao MLP, que os sulcos e fissuras seladas com CIV Fuji III $\quad$ \&ão mais resistentes à desmineralização, mesmo após a perda macroscópica do material, como resultado do efeito combinado do flúor iberado pelo CIV e o material residual no fundo dos sulcos e fissuras.

TANTBIROJN; DOUGLAS; VERSLUIS ${ }^{116}$ (1997) também observaram em seu estudo, uma inibição da desmineralização com o selante de CIV Vitremer ${ }^{\circledR}$ até a distância de $7 \mathrm{~mm}$, com maior eficácia do flúor liberado em cerca de $1 \mathrm{~mm}$ ao redor do CIV. Acrescenta-se à este dado, a presença de tags resinosos nos 
materiais polimerizados por luz, que aumentaria a resistência do esmalte ao ataque de cárie, em comparação ao quimicamente ativado, o que limitaria o desenvolvimento da lesão, ou seja, sua área, como observado no presente estudo, entre outros (HICKS; SILVERSTONE ${ }^{51}$, 1982 e MERTZ-FAIRHURST et al. ${ }^{72}$, 1984).

Todos estes fatores apresentados até o momento, explicariam os melhores resultados obtidos com os materiais seladores fluoretados estudados no presente trabalho quanto sua eficácia estatisticamente significante em reduzir a área de lesão, quando comparado com o grupo do selante resinoso sem flúor e o controle.

Com relação ao CIV de presa rápida Ketac Molar $\AA^{\circledR}$, este não apresentou resultado satisfatório quando considerada a profundidade da lesão, assim como o selante resinoso fluoretado Fluroshield ${ }^{\circledR}$. Apesar de não ter sido avaliado no presente estudo, a ocorrência de microinfiltração na interface esmalte / selante poderia explicar estes resultados negativos.

De acordo com HICKS; SILVERSTONE ${ }^{51}$ (1982), a integridade da interface esmalte / selante determina, em grande extensão, a habilidade em reduzir a ocorrência de lesão de cárie do material selador. São os gaps presentes nesta interface que permitem que haja uma frente adicional de difusão de íons hidrogênio e a conseqüente formação de lesões ao longo da parede dos sulcos e fissuras, ou seja, em maior profundidade.

COUTINHO; PEREIRA; BIJELLA ${ }^{19}$ (1999) observaram in vitro ocorrência de microinfiltração ao microscópio óptico, tanto em fissuras rasas quanto profundas, seladas com Delton $\AA$ e Fluroshield $\AA$, sem diferença estatística entre eles. Já ÖVREBÖ; RAADAL ${ }^{86}$ (1990), em estudo anterior, encontraram uma maior 
microinfiltração marginal do CIV convencional Fuji III ® utilizado para selamento quando comparado com o selante resinoso Concise ${ }^{\circledR}$. Fato observado, também, por SMALES; GAO; HO ${ }^{109}$ (1997) com os CIV de presa rápida Fuji IX ®, Fuji IX GP ®, Fuji IX GP $®$ encapsulado e Ketac Molar Prototype $®$ utilizados como selante, mesmo apresentando boa penetração nos sulcos e fissuras, como demonstrado por outros estudos (VELASCO; NÖR; FIGUEIREDO ${ }^{124}$, 1996, MONICO; TOSTES ${ }^{74}$, 1998 e FRACASSO $\left.{ }^{35}, 2001\right)$.

Com relação a este aspecto, o CIV modificado Vitremer ${ }^{\circledR}$ apresenta boa penetração nos sulcos e fissuras quando comparado com o selante resinoso Concise ${ }^{\circledR}$ e o CIV de presa rápida Fuji IX ${ }^{\circledR}\left(\right.$ MOORE et al. ${ }^{76}, 1995$ e ABREU ${ }^{1}$, 1997); e no presente estudo, o Vitremer ® obteve melhor resultado, estatisticamente significante, do que o CIV de presa rápida Ketac Molar ${ }^{\circledR}$, apenas quanto ao fator profundidade da lesão, mas não em relação à área, que não foi encontrada diferença estatística.

Apesar da técnica de inserção do CIV Ketac Molar @ ter seguido as recomendações do fabricante para a Técnica Restauradora Atraumática, podem ter ocorrido falhas no selamento que poderiam estar relacionadas à sua aplicação em sulcos e fissuras rasas ou à adesão insuficiente do ionômero de vidro àsuperfície de esmalte, devido a sua maior viscosidade e a formação de bolhas, como observado no estudo de SMALES; GAO; HO (1997) ${ }^{109}$, já que na ART usa-se o mesmo CIV restaurador para selamento. Neste caso, uma maior microinfiltração pode ter ocorrido na interface esmalte / selante, permitindo uma maior profundidade da lesão. Porém, devido ao flúor presente no CIV Ketac Molar ${ }^{\circledR}$, esta lesão não se propagou durante os 14 dias de ciclagem do experimento, tendo sua área reduzida, fato observado também no selante resinoso fluoretado Fluroshield $\AA$. 
A susceptibilidade à cárie dentária apresentada pela superfície oclusal tem levado os pesquisadores a buscarem métodos preventivos para o controle dessas lesões. Foram sugeridos, ao longo do século passado, diferentes procedimentos clínicos, desde a odontotomia profilática, passando pela erradicação das fissuras do esmalte e os métodos químicos; todos estes procedimentos visando prevenir cáries oclusais, entretanto, com valor limitado.

Os selantes, por sua característica adesiva, atuam penetrando nos sulcos e fissuras criando uma barreira física nestas superfícies, impedindo o contato do biofilme bacteriano com a estrutura dentária. Tanto os selantes resinosos àbase de BisGMA quanto os cimentos ionoméricos modificados por resina como o Vitremer ${ }^{\circledR}$, por sua capacidade de liberação de flúor, exercem um efeito cáriepreventivo, entretanto em pacientes com alta atividade de cárie dentária, o material mais indicado seria o CIV modificado.

\subsection{Avaliação do potencial cariostático do verniz fluoretado e do diamino fluoreto de prata}

Observou-se, neste estudo, com relação à profundidade da lesão de cárie artificial vista ao MLP que os menores valores foram verificados com o uso do verniz fluoretado Duraflur $\AA$, seguido do DFP Safluoride $\AA$ e do CIV modificado Vitremer ${ }^{\circledR}$, sendo os dados estatisticamente significantes quando comparados com - CIV de presa rápida Ketac Molar $\AA$ e os selantes resinosos Fluroshield ${ }^{\circledR}$ e Delton ${ }^{\circledR}$, os quais não diferiram do controle (Tab. 1, p. 58 e Fig. 3, p. 60). Quanto à área da lesão, os menores valores foram observados no grupo do CIV Vitremer $®$, 
seguido pelo verniz Duraflur $\AA$, DFP Safluoride ${ }^{\circledR}$, CIV Ketac Molar ${ }^{\circledR}$ e selante resinoso Fluroshield $\AA$, sendo os dados estatisticamente significantes quando comparado com o grupo controle e do selante Delton ${ }^{\circledR}$, que não diferiram entre si (Tab. 2, p. 59 e Fig. 4, p. 60).

Os dados deste estudo estão em desacordo com VAN DORP; TEN CATE ${ }^{122}$ (1992), que em um estudo in vitro ao MLP e através da análise de radiografias, encontraram uma superioridade do selante Delton $\AA$ e White Sealant $₫$

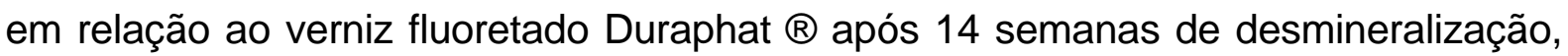
em reduzir a progressão de cárie nas paredes dos sulcos e fissuras, quando o selante estava intacto. No entanto, os autores consideraram que o grupo do Delton ${ }^{\circledR}$ apresentou maior progressão lateral da desmineralização, enquanto que no grupo do verniz fluoretado, a extensão da lesão de cárie permaneceu limitada à parede dos sulcos e fissuras, resultado este similar ao presente estudo. Na análise das Figuras 5 e 6 (p. 61 e 62) obtidas do MLP, pode-se observar a presença de lesões mais extensas na região de sulcos e fissuras em amostras dos grupos controle e do selante resinoso Delton ${ }^{\circledR}$, quando comparado com o grupo do verniz fluoretado (Fig. 11, p. 67).

Ainda, HOLMEN et al. ${ }^{56}$ (1986), utilizando o MLP e o MEV, relataram, após o uso do verniz fluoretado Duraphat $\AA$, uma redução na porosidade subsuperficial de lesões artificiais de cárie incipiente produzidas experimentalmente in vivo, com significativa redistribuição dos minerais no interior das lesões e com penetração de flúor nas áreas mais profundas da lesão. Igualmente, MÖLLER; SCHRÖDER ${ }^{73}$ (1986) observaram ao MEV, após tratamento in situ de lesões naturais de cárie proximal de subsuperfície com verniz fluoretado Duraphat $\AA^{\circledR}$ a cada 10 dias durante 8 a 10 semanas, uma aparência mais regular e homogênea das 
áreas remineralizadas que apresentaram cristais maiores e compactados, indicando uma reversão da lesão de cárie não só superficialmente, mas também nas partes mais profundas da mesma. O resultado clínico demonstrou redução no tamanho das lesões, com estas apresentando-se mais lisas e brilhantes, apesar da metodologia empregada nesses trabalhos serem diferentes ao deste estudo.

Os dados encontrados no presente trabalho, também, estão de acordo com os achados de HEUSER; SCHMIDT $^{47}$ (1968), que observaram uma redução de $70 \%$ de lesão de cárie de sulcos e fissuras em ratos com o uso do verniz fluoretado Duraphat $\AA$, apesar dos materiais e métodos serem diferentes aos deste estudo. Ainda, SEPPÄ ${ }^{100}$ (1988) e ERONAT; ERONAT; ALPÖZ ${ }^{27}$ (1993) encontraram em seus estudos in vitro, apesar das metodologias empregadas serem diferentes, uma superioridade dos vernizes fluoretados em relação à inibição da progressão de lesões de cárie, com maior resistência da estrutura adamantina à desmineralização ácida quando comparado com outros métodos de aplicação tópica de flúor. SORVARI et al. ${ }^{111}$ (1994) e MEDEIROS; BRUM ${ }^{69}$ (1998) observaram, igualmente, uma maior proteção do esmalte após a aplicação do verniz fluoretado Duraphat ${ }^{\circledR}$, previamente à sua imersão em soluções ácidas, com aumento da resistência deste esmalte àerosão.

Outros estudos, também, apesar de usarem metodologias diferentes ao desta pesquisa, demonstraram a superioridade de um verniz fluoretado aplicado especificamente em sulcos e fissuras, como os de SEPPÄ et al. ${ }^{105}$ (1988), que observaram em ratos redução de $43 \%$ nas lesões de cárie oclusal envolvendo a junção amelo-dentinária e de $65 \%$ nas lesões envolvendo a dentina e o de HUANG et al. ${ }^{58}$ (2001) que, utilizando molares humanos, obtiveram uma inibição de $43 \%$ das lesões de cárie nesta superfície, quando analisada ao MLP. Também, SEPPÄ; 
FORSS; SORMUNEN 104 (1989), trabalhando em ratos consideraram essa superioridade.

YANOVER ${ }^{130}$ (1982), em sua revisão de literatura, relatou que o verniz fluoretado é um veículo de fornecimento de íon flúor em alta concentração, sendo o método mais eficiente para a superfície oclusal, devido a sua maior aderência æ̀s partes mais profundas dos sulcos e fissuras, permitindo um maior tempo de contato com o esmalte.

De acordo com KOCH; PETERSSON ${ }^{63}$ (1972) em seu estudo in vitro, a aquisição de flúor pelo esmalte após a aplicação do verniz fluoretado Duraphat ${ }^{\circledR}$ tende a ser maior após a exposição de 12 horas, principalmente na profundidade de $20-50 \mu \mathrm{m}$. De BRUYN et al. ${ }^{21}$ (1988) estudando, in situ, a influência dos vernizes fluoretados Fluor Protector $\AA$ e Duraphat $®$ na perda mineral sob a placa bacteriana no período de 2, 4 e 6 meses, relataram que, após 4 meses, o Fluor Protector ${ }^{\circledR}$ mostrou melhor propriedade protetora contra a perda mineral do que o Duraphat $\AA$, no entanto, após 6 meses, o efeito protetor dos vernizes testados foi similar, não apresentando diferença estatisticamente significante, o que confirma a ação cariostática prolongada do Duraphat $\AA^{\circledR}$. Também, SOUZA ${ }^{113}$ (1992), analisando in situ o $\mathrm{CaF}_{2}$ formado e retido após 1 e 8 dias da aplicação de gel de FFA a 1,23\% e do verniz fluoretado Duraphat ${ }^{\circledR}$ no esmalte humano hígido e cariado, encontrou uma maior concentração deste composto formado após 0 8ำ dia decorrido da aplicação do verniz quando comparado ao $1^{\circ}$ dia, concluindo que este $\mathrm{CaF}_{2}$ formado após a aplicação do verniz seria mais estável, tendo este produto uma indicação mais terapêutica por liberar o íon flúor mais lentamente, durante os desafios cariogênicos. Os resultados foram corroborados por CRUZ; ÖGAARD; RÖLLA 20 (1992), que observaram, in vitro, após a imersão em água de amostras de esmalte 
tratadas com verniz fluoretado, que estas liberaram apenas 50\% dos depósitos de flúor formados no esmalte em comparação æ̀s tratadas com solução de fluoreto de sódio a $2 \%$.

É importante considerar, ainda, que apesar da remoção do excesso do verniz aplicado ter sido realizada neste estudo com Hollenback e acetona, como preconizado por VAN DORP; TEN CATE ${ }^{122}$ (1992), remanescentes do produto podem ter ficado aderido aos sulcos e fissuras, devido a sua alta viscosidade, formando uma barreira contra a progressão da lesão de cárie, pois de acordo com SEPPÄ; LUOMA ${ }^{103}$ (1983), o flúor presente no esmalte dos sulcos e fissuras pode se originar destes vestígios retidos do verniz. As autoras relataram que o verniz, com sua alta viscosidade, penetra nas porosidades do esmalte, formando "tags" de 0,5 1,0 $\mu \mathrm{m}$ de comprimento e que esse efeito "tag" agiria como um depósito de flúor, uma vez que essa camada de esmalte de 1,0 $\mu$ m ficaria preservada durante 0 estudo, formando $\mathrm{CaF}_{2}$ nesta superfície.

Sabe-se que a eficiência das aplicações tópicas de flúor relaciona-se diretamente com o período de exposição do esmalte ao agente terapêutico, sendo um mecanismo de ação dinâmico, inibindo a desmineralização e potencializando a remineralização. Assim, a presença de flúor pode induzir a paralização de lesões de cárie, diminuindo a probabilidade de uma lesão incipiente progredir até um estágio de cavitação.

Desse modo, o verniz fluoretado apresenta uma ação antibacteriana contra os microrganismos presos nos sulcos e fissuras e também uma maior incorporação de flúor pelo esmalte, além de uma liberação progressiva desse íon por um certo período de tempo, com uma redução da lesão de cárie reportada em cerca 
de $56 \%$ neste sítio por HOLM et al ${ }^{54}$ (1984), sendo assim, uma alternativa ao uso de selamentos oclusais.

Além disso, apesar da maioria dos trabalhos na literatura avaliarem a eficácia do verniz fluoretado alemão Duraphat ${ }^{\circledR}$, MEDEIROS; MENDONÇA ${ }^{70}$ (1997) ao compararem in vitro e in situ este produto com o similar nacional Duraflur $\AA$, o mesmo utilizado nesta pesquisa, observaram que ambos os vernizes foram capazes de depositar $\mathrm{CaF}_{2}$ sobre o esmalte hígido, após 1 e 2 semanas, tanto in vitro como in situ, tendo o verniz Duraflur $\AA$, dentre os vernizes nacionais avaliados, o que obteve o melhor resultado.

BERGAMASCHI; DELBEM; SASSAKI ${ }^{9}$ (2001), ao compararem in vitro o efeito anticariogênico do flúor liberado pelo verniz fluoretado e pelo DFP, utilizando ciclagens de $\mathrm{pH}$ como neste estudo, observaram menor perda mineral do esmalte bovino com a aplicação do verniz fluoretado em relação ao DFP. Por outro lado, SOUSA NETTO; ALMEIDA; CURY ${ }^{112}$ (1999), em seu estudo in situ com dentina bovina desmineralizada artificialmente, encontraram um maior índice de recuperação da microdureza superficial com o uso do DFP a 30\% em comparação com o verniz fluoretado, sendo os resultados estatisticamente significantes, apesar de ambos os materiais remineralizarem a dentina bovina. Entretanto, nesses estudos os métodos utilizados foram diferentes desta pesquisa.

No presente estudo que utilizou molares permanentes humanos inclusos, não foi observada diferença significante entre ambos os materiais tanto ao nível de profundidade $(0,61 \mu \mathrm{m}$ para o DFP e 0,29 $\mu \mathrm{m}$ para o verniz fluoretado) quanto de área $\left(2,86 \mu m^{2}\right.$ e $1,78 \mu m^{2}$, respectivamente) da lesão artificial de cárie na superfície oclusal. Este dado pode ser verificado nas Tabelas 1 e 2 (p. 58 e 59), nos gráficos das Figuras 3 e 4 (p. 60) e nas Figuras 10 e 11 (p. 66 e 67) obtidas do MLP. 
Este efeito cariostático observado está relacionado, também, àcapacidade do DFP em produzir, ao entrar em contato com o esmalte, neste caso o da superfície oclusal, precipitados insolúveis de $\mathrm{CaF}_{2}$ e fosfato de prata, promovendo uma barreira à progressão de lesões de cárie, conforme demonstrado nos trabalhos de NISHINO ${ }^{83}$ (1969) e de OKAMOTO; MONOMURA; SOBUE ${ }^{85}$ (1975). Estes compostos ficam precipitados sobre a superfície dos dentes; o $\mathrm{CaF}_{2}$ dissocia-se em íons flúor e íons cálcio e o íon flúor liberado reage com a hidroxiapatita sendo gradualmente convertido em fluorapatita que é extremamente resistente à descalcificação pelos ácidos e agentes quelantes. Além disso, os íons prata e o flúor tem atividade antimicrobiana contra os microrganismos cariogênicos. Resultados, também, obtidos por NISHINO; MASSLER ${ }^{84}$ (1977) com DFP a 38\% e por GARBELINI ${ }^{38}$ (1989), utilizando DFP a 30\% observaram redução na incidência de lesões de cárie em esmalte e em dentina superficial em sulcos e fissuras de molares de rato, tendo o produto prevenido e paralisado o progresso das lesões, comprovando seu efeito cariostático e anticariogênico, com diminuição da atividade microbiana, apesar das metodologias serem diferentes. As Figuras 15 e 16 (p. 71 e 72) do MLP demonstram a ocorrência destas áreas de remineralização na região de sulcos e fissuras, observadas no presente trabalho em amostras dos grupos do DFP e do verniz fluoretado, respectivamente, fato que não foi observado nas amostras dos grupos controle e do selante resinoso Delton ${ }^{\circledR}$.

Estudos bacteriológicos demonstraram que a aplicação tópica de DFP sobre lesões de cárie causa redução marcante da proporção de Streptococcus mutans e na superfície do esmalte sadio inibe a formação do biofilme dentário e a desmineralização subsuperficial do mesmo $^{59,75,107,120,121 .}$ 
No presente estudo, os resultados promissores obtidos com o DFP a $30 \%$ aplicado in vitro em sulcos e fissuras, o torna uma alternativa menos dispendiosa que a associação flúor/selamento para a superfície oclusal, proporcionando um tratamento mais ao alcance de todas as pessoas, especialmente as de menor poder aquisitivo. Vale ressaltar que muitos profissionais ainda relutam em utilizar o DFP devido ao seu efeito anti - estético de escurecimento de lesões iniciais descalcificadas. Apesar dos diferentes materiais fluoretados, também com propriedades cariostáticas existentes no mercado, estes apresentam custo mais elevado e técnica de trabalho, muitas vezes incompatível com o público alvo que necessita deste tipo de cuidado odontológico. Desse modo, o DFP seria uma opção a mais, ou, muitas vezes, a única opção de tratamento.

BIJELLA et al. ${ }^{12}$ (1991) encontraram em seu estudo in vivo, apesar de utilizarem a solução de DFP a 12\%, expressiva ação cariostática da solução nos dentes decíduos, com redução de 38,05\% a 69,02\% e uma diminuição na incidência de lesão de cárie nos primeiros molares permanentes que irromperam após o uso do DFP na dentição decídua de 43,93\% a 63\%, comprovando as propriedades cariostáticas, anticariogênicas e bactericidas do produto. ALMEIDA ${ }^{2}$ (1993), utilizando o mesmo produto também in vivo, observou após 1 ano de acompanhamento, em crianças de risco na faixa etária de 5 ُ 6 anos, um efeito cariostático e anticariogênico da solução aplicada nos dentes decíduos e nos molares permanentes recém irrompidos, além de efeito antimicrobiano com diminuição nos níveis salivares dos Streptococcus mutans nas crianças que receberam a solução em todos os dentes presentes na cavidade bucal exceto os primeiros molares permanentes. 
No presente estudo, como não foram observadas diferenças significativas com a utilização do verniz fluoretado e do DFP na superfície oclusal com relação ao seu potencial cariostático, ambos os produtos tornam-se uma alternativa viável ao alcance do profissional, para a prevenção da ocorrência de lesões de cárie oclusal em pacientes de risco e, também, como agentes terapêuticos para pacientes em atividade de cárie, principalmente bebês e crianças jovens, durante os períodos de "janela de infectividade", devido a sua facilidade de aplicação e menor tempo de trabalho, sendo de grande vantagem na Odontopediatria.

A rotina de aplicação do selamento era recomendada para todos os dentes posteriores. Contudo, com o conhecimento atual acerca do início e progressão das lesões de cárie oclusal, o selamento passou a ser indicado de forma mais criteriosa e seletiva, visando uma relação custo-benefício favorável para este tipo de procedimento. Assim, a aplicação de outros agentes inibidores efetivos, tanto para prevenir quanto para deter lesões de cárie oclusal já existentes, começou a ser levada em consideração pelos pesquisadores, apresentando também relativo sucesso em inibir a desmineralização nesta superfície.

Tem-se como exemplo, neste caso, o uso de compostos fluoretados, como as soluções de DFP e os vernizes fluoretados que ao serem aplicadas no esmalte promovem a formação de fluoreto de cálcio $\left(\mathrm{CaF}_{2}\right)$ que age como um reservatório de liberação lenta de íon flúor, maximizando o tempo de exposição deste no esmalte, promovendo a interrupção do progresso de lesões de cárie subclínicas incipientes em sulcos e fissuras, em seus primeiros estágios, tendo efeito cariostático e preventivo, reduzindo a solubilidade do esmalte frente ao ataque ácido. 
No entanto, conforme já relatado, poucos estudos realizaram uma comparação direta destes diferentes tratamentos preventivos de lesão de cárie, visando especificamente a superfície oclusal, o que motivou a realização da presente pesquisa com o objetivo de buscar mais informações.

Assim, com base nos resultados deste estudo e na mudança dos paradigmas quanto à prevenção de cárie na superfície oclusal, considerando -se as necessidades particulares de cada dente e do paciente é válido indicar o uso de vernizes fluoretados ou soluções a base de DFP, devido a suas propriedades cariostáticas, nos casos em que os fatores etiológicos e determinantes da doença cárie sejam passíveis de controle. Já, os selamentos seriam indicados de forma mais restrita, para sulcos e fissuras hígidos ou com lesão em esmalte, em pacientes cujos fatores etiológicos e determinantes relacionados com a iniciação e com a evolução das lesões de cárie sejam de difícil controle, sendo que o cimento ionomérico modificado por resina Vitremer ${ }^{\circledR}$ utilizado para selamento de sulcos e fissuras neste caso, torna-se uma boa alternativa de escolha, durante o período de aumento de risco do paciente, apesar que talvez nestes casos deveria-se utilizar o verniz fluoretado ou o DFP (de acordo com sua indicação) inicialmente, antes do selamento com CIV.

Deve-se salientar, contudo, que por ser este um estudo in vitro baseado em um modelo de cárie artificial, são necessários mais estudos longitudinais, principalmente in vivo, para que sejam corroborados os resultados aqui obtidos. 
7 CONCLUSÕES 


\section{CONCLUSÕES}

Com base na metodologia empregada e nos resultados obtidos é lícito concluir que:

1. houve diferença, estatisticamente significante $(p<0,001)$, com relação ao potencial cariostático, entre os materiais aplicados na superfície oclusal tanto ao nível de profundidade quanto de área da lesão;

2. apesar de não impedirem totalmente o desenvolvimento de lesões de cárie artificiais na superfície oclusal, os tratamentos do Grupo VII (verniz fluoretado Duraflur $\AA^{\circledR}$ ), do Grupo VI (solução de diamino fluoreto de prata Safluoride $\AA^{\circledR}$ ) e do Grupo V (cimento de ionômero de vidro modificado por resina Vitremer ${ }^{\circledR}$ ) apresentaram os menores valores de profundidade da lesão em ordem crescente, sem diferença estatística entre eles $(0,29 \mu \mathrm{m}, 0,61 \mu \mathrm{m}$ e $0,89 \mu \mathrm{m}$, respectivamente);

3. os tratamentos do Grupo IV (cimento de ionômero de vidro de presa rápida Ketac Molar $\AA$ ), do Grupo II (selante resinoso sem flúor Delton $\AA^{\circledR}$ ) e do Grupo III (selante resinoso fluoretado Fluroshield $\AA$ ) não diferiram estatisticamente do Grupo I (controle) com relação à profundidade da lesão $(3,69 \mu \mathrm{m}, 3,67 \mu \mathrm{m}$, $2,10 \mu \mathrm{m}$ e $5,81 \mu \mathrm{m}$, respectivamente);

4. com relação à área da lesão, os tratamentos do Grupo V (cimento de ionômero de vidro modificado por resina Vitremer $®$ ), do Grupo VII (verniz fluoretado Duraflur $\AA$ ), do Grupo VI (solução de diamino fluoreto de prata Safluoride $\AA$ ), do Grupo IV (cimento de ionômero de vidro de presa rápida Ketac Molar ${ }^{\circledR}$ ) e do 
Grupo III (selante resinoso fluoretado Fluroshield $\circledast$ ) apresentaram os menores valores, sem diferença estatística entre eles $\left(0,81 \mu \mathrm{m}^{2}, 1,78 \mu \mathrm{m}^{2}, 2,86 \mu \mathrm{m}^{2}, 3,69\right.$ $\mu \mathrm{m}^{2}$ e $4,91 \mu \mathrm{m}^{2}$, respectivamente), enquanto o Grupo II (selante resinoso sem flúor Delton $\left.\AA^{\circledR}\right)$ apresentou o maior valor, não diferindo estatisticamente do Grupo I (controle) $\left(16,39 \mu \mathrm{m}^{2}\right.$ e $25,04 \mu \mathrm{m}^{2}$, respectivamente);

5. o uso de materiais fluoretados parece ter um papel importante no controle da instalação e/ou da progressão de lesões de cárie na superfície oclusal, quando comparados ao selante resinoso sem flúor e o não selamento, sobretudo em situações de alto desafio cariogênico como as deste estudo. 
ANEXOS 


\section{ANEXO A}

\section{DECLARAÇÃO}

Declaro que doei à Faculdade de Odontologia de Bauru - USP, 70 terceiros molares permanentes, humanos, hígidos, extraídos por indicaçäo clínica ou ortodôntica, oriundos do arquivo de dentes da disciplina de Cirurgia Bucal e do Curso de Atualização em Cirurgia Bucal da FO - UFF, para fins de pesquisa.

Niterói,

Rutessor- Juan P. Apaca Arce

Coordenase do Curto de

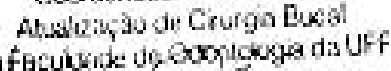

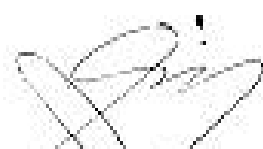
$\rightarrow>$

Prof. Dr. Juan T. Alpaca Arce

Coordenador da Disciplina de Cirurgia Bucal e do Curso de Atualizaçäo em Cirurgia Bucal da FO -UFF 


\section{ANEXO B}

\section{TERMO DE COMPROMISSO}

Declaro que usaremos os dentes oriundos do arquivo de dentes da disciplina de Cirurgia Bucal e do Curso de Atualização em Cirurgia Bucal da FO - UFF e que os mesmos nāo recebem identificaçăo e foram doados espontaneamente para fins de pesquisa na Faculdade de Odontologia de Bauru - USP.

A principal justificativa para a utilizaçāo de dentes humanos é avaliar materiais em condiçōes próximas ou semelhantes às condiçōes da cavidade bucal.

Maria Francisca Thereza Borro Bijella

Professora Orientadora

Pesquisadora Responsável

Thereza Christina Lopes Coutinho

Doutoranda 


\title{
ANEXO C
}

\author{
Universidade de São Paulo \\ Faculdade de Odontologia de Bauru \\ At Dr. Octávo Puhlero Brisolia, 9-75 - Bauru-SP - CEP $17012-901$ - C.P.73 \\ PABX 10XX14)235-8000- $13 \times(0 \times \times 14) 223-4679$ \\ Gorith de Efica om Pescuriso
}

Bauru, 19 de agosto de 2002

Senhora Professora.

Informamos que após o envio da documentaçäo pendente, o projeto de pesquisa encaminhado a este Comité denominado "Aplicą̧āo tôpica do verniz com fluor e do selamento com cimento de ionómero de vidro modificado por resina na remineralizaçāo in situ de fesōes artificiais de carie oclusal em molares permanentes", de autotia de Thereza Chistina Lopes Coutinho, que será desenvolvido sob a sua orientaçāo, foi APROVADO

Comunicamos que após o envio do trabalho concluido, este Comitê enviarà o parecer final, que será utilizado para a publicaçäo do trabalho

Atenciosamente.

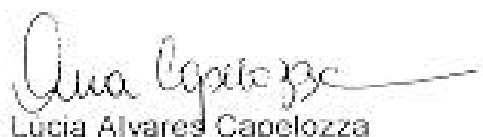

Prof* Dra Ana Lucia Alvares Capelozza

Coordenadora do Comité de Etica em Pesquisa em Setes Humanos

$1 / \mathrm{m}^{3} \mathrm{Sr}^{\mathrm{a}}$ Profo $\mathrm{D}^{3}$ Maria Francisca Thereza Borro Bijella

DD. Docente do Departamento de Odontopediatria, Ortodontia e Saude Coletiva 


\section{REFERÊNCIAS BIBLIOGRÁFICAS}




\section{REFERÊNCIAS BIBLIOGRÁFICAS*}

1. ABREU, K.C.S. de. Avaliação microscópica da profundidade de penetração em fóssulas e fissuras, de materiais contendo cimento de ionômero de vidro, utilizados como selantes. Bauru, 1997. 125 p. Dissertação (Mestrado) - Faculdade de Odontologia de Bauru, Universidade de São Paulo.

2. ALMEIDA, I.C.S. Avaliação dos efeitos cariostático, anticariogênico e antimicrobiano da solução de diaminofluoreto de prata a $12 \%$ (Bioride), em crianças de 5 1/2a 6 anos. Bauru, 1993. 117 p. Tese (Doutorado) Faculdade de Odontologia de Bauru, Universidade de São Paulo.

3. ANDRADE, K.C.G.E. et al. Reações da dentina cariada humana após aplicação do diamino fluoreto de prata a $10 \%$. Estudo através de microscópio eletrônico de varredura. Rev. bras. Odont., v. 49, n. 6, p. 31-6, nov./dez. 1992.

4. ARENDS, J.; SCHUTHOF, J. Fluoride content in human enamel after fluoride application and washing - an in vitro study. Caries Res., Basel, v. 9, p. 36372, 1975.

5. ARENDS, J.; LODDING, A.; PETERSSON, L.G. Fluoride uptake in enamel. In vitro comparison of topical agents. Caries Res., v. 14, p. 403-13, 1980.

6. ARROW, P. Oral hygiene in the control of occlusal caries. Community Dent. oral Epidem., v. 26, p. 324-30, 1998.

7. ASSIS, E.Q.; CIAMPONI, A.L.; CORREA, M.S.N.P. Vernizes com flúor: revisão da literatura. Rev. Odontoped., v. 1, n. 1, p. 24-34, jan./mar. 1992.

8. BAWDEN, J.W. Fluoride varnish: a useful new tool for public health dentistry. J. Publ. HIth. Dent., v. 58, n. 4, p. 266-9, Fall 1998.

9. BERGAMASCHI, M.; DELBEM, A.C.B.; SASSAKI, K.T. Atividade anticariogênica do Duraphat e Safluoride di Walter. Pesq. Odont. Bras., v. 15, p. 151, set. 2001. Suplemento.

10. BERMAN, D.S.; SLACK, G.L. Susceptibility of tooth surfaces to carious attack. A longitudinal study. Brit. Dent. J., v. 134, n. 4, p. 135-9, Feb. 20, 1973.

\footnotetext{
* Normas recomendadas para uso no âmbito da Universidade de São Paulo, com base no documento "Referências Bibliográficas: exemplos", emanado do Conselho Supervisor do Sistema Integrado de Bibliotecas da USP, em reunião de 20 de setembro de 1990.
} 
11. BIJELLA, M.F.T.B.; SILVA, S.M.B. da; MACHADO, M.A.A.M. Uso tópico das soluções de diaminofluoreto de prata. CECADE News, v. 1, n. ,3/p. $1-12$, set./dez. 1993.

12. BlJELLA, M.F.T.B. et al. Avaliação clínica da aplicação de diamino-fluoreto de prata a $12 \%$ (Bioride) na dentição decídua e seu efeito na incidência de cárie em primeiros molares permanentes. Rev. paul. Odont., v. 13, n. 1, p. 28-35, jan. 1991.

13. BRAVO, $M$ et al. A 24-month study comparing sealant and fluoride varnish in caries reduction on different permanent first molar surfaces. J. Publ. HIth. Dent., v. 57, n. 3, p. 184-6, 1997a.

14.

A 48-month survival analysis comparing sealant (Delton) with fluoride varnish in 6- to-8-year-old children. Community Dent. oral Epidem., v. 25 , p. $247-50,1997 b$.

15. BRUUN, C. et al. Three-year caries increments after fluoride rinses or topical applications with a fluoride varnish. Community Dent. oral Epidem., v. 13, p. 299-303, 1985.

16. CARVALHO, J. C.; THYLSTRUP A. ; EKSTRAND, K.R. Results after 1 year of non-operative occlusal caries treatment of erupting permanent first molars. Community Dent. oral Epidem., v. 19, p. 23-8, Jan. 1991.

17. CARVALHO, J. C. et al. Dental plaque and caries on occlusal surfaces of first permanent molars in relation to stage of eruption. J. dent. Res., v. 68, n. 5, p. 773-9, Sept./Oct. 1989.

18. COOLEY, R.L. et al. Evaluation of a fluoride-containing sealant by SEM, microleakage, and fluoride release. Pediat. Dent., v. 12, n. 1, p. 38-42, Feb. 1990.

19. COUTINHO, T.; PEREIRA, E.; BIJELLA, M.F.T.B. Microleakage and penetration of two pit and fissure sealants. J. dent. Res., v. 78, p. 476, Mar. 1999. Special issue.

20. CRUZ, R.A.; ÖGAARD, B.; RÖLLA, G. Uptake of $\mathrm{KOH}$-insoluble fluoride in sound human enamel after topical application of a fluoride varnish (Duraphat) or a neutral $2 \% \mathrm{NaF}$ solution in vitro. Scand. J. dent. Res., v. 100, n. 3, p. 154-8, Jun. 1992.

21. De BRUYN, $\mathrm{H}$. et al. Influence of various fluoride varnishes on mineral loss under plaque. Caries Res., v. 22, p. 76-83, 1988.

22. DECICO, H.M.U. et al. Avaliação de selante fluoretado quando submetido in vitro a ciclagens térmicas e de Des-Remineralização. In: REUNIÃO ANUAL DA SOCIEDADE DE PESQUISAS ODONTOLÓGICAS, 11., 1994, Águas de São Pedro, Anais... São Paulo, SBPqO, 1994. p. 9. 
23. EDENHOLM, $\mathrm{H}$. et al. Fluoride uptake and release in deciduous enamel after application of fluoride varnishes. Swed. Dent. J., v. 1, p. 59-64, 1977.

24. EKSTRAND, J. Fluoride concentrations in saliva after single oral doses and their relation to plasma fluoride. Scand. J. dent. Res., v. 85, n. 1, p. 16-7, Jan. 1977

25. Pharmacocinetic aspects of topical fluorides. J. dent. Res., v. 66, n. 5, p. 1061-5, May 1987

26. EKSTRAND, J.; FEJERSKOV, O.; SILVERSTONE, L.M. Fluorides in dentistry. Copenhagen, Munksgaard, 1988. p. 125-49.

27. ERONAT, C.; ERONAT, N.; ALPÖZ, A.R, Fluoride uptake by enamel in vitro following application of various topical fluoride preparations. J. Clin. Pediat. Dent., v. 17, n. 4, p. 227-30, July 1993.

28. FEATHERSTONE, J.D.B. et al. Remineralization of artificial caries-like lesions in vivo by a self administered mouthrinse or paste. Caries Res., v. 16, p. 23542, 1982.

29. Enhancement of remineralization in vitro and in vivo. In: $\mathrm{LEACH}, \mathrm{S} . \mathrm{A}$. Factors relating to demineralization and remineralization of the teeth. Oxford, IRL Press Ltd., 1986. p. 23-34.

30. FEHR, F.R. von der. Epidemiology of dental caries. In: THYLSTRUP, A.; FEJERSKOV, O. Textbook of cariology. Copenhagen, Munksgaard, 1986. p. 266-75.

31. FENNIS-LE, Y. L. et al. Effect of 6-monthly applications of chlorexidine varnish on incidence of occlusal caries in permanent molars: a 3-year study. J. Dent., v. 26, n. 3, p. 233-8, Mar. 1998.

32. FIGUEIREDO, M.C.; PAVARINI, A. Microscope evaluations of sealant with and without inorganic particles and tag formations. J. dent. Res., v.75, p. 180, Mar. 1996. Special issue.

33. FIGUEIREDO, M.C. et al. Cimento de ionômero de vidro FUJI IX: Análise in vitro da liberação de flúor. In: REUNIÃO ANUAL DA SOCIEDADE DE PESQUISAS ODONTÓlÓGICAS, 13., 1996, Águas de São Pedro. Anais... São Paulo, SBPqO, 1996. p. 159.

34. FORSS, H. ; HALME, E. Retention of a glass ionomer cement and a resinbased fissure sealant and effect on carious outcome after 7 years. Community Dent. oral Epidem., v. 26, p. 21-5, Jan.1998.

35. FRACASSO, M.L.C. Avaliação da infiltração marginal e da profundidade de penetração apresentada por alguns cimentos de ionômero de vidro e um selante resinoso aplicados em fossas e fissuras oclusais: estudo 
in vitro. Bauru, 2001. 139 p. Dissertação (Mestrado) - Faculdade de Odontologia de Bauru, Universidade de São Paulo.

36. FRENCKEN, J.E. et al. An atraumatic restorative treatment (ART) technique: evaluation after one year. Int. dent. J., v. 44, n. 5, p. 460-4, 1994.

37. GAO, W.; SMALES, R.J.; LAM, W.T.C. Fluoride release and weight loss from ART technique GICs. J. dent. Res., v. 76, p. 316, Mar. 1997. Special issue.

38. GARBELINI, W.T. Verificação dos efeitos anticariogênicos e cariostáticos do diamino fluoreto de prata a $\mathbf{3 0 \%}$ em molares de rato. 1989.70 p. Dissertação (Mestrado) - Faculdade de Odontologia de Bauru, Universidade de São Paulo, Bauru, 1989.

39. GARCIA-GODOY, F. et al. Fluoride release from fissure sealants. J. Clin. Pediat. Dent., v. 22, n. 1, p. 45-9, Fall 1997.

40. GELHARDS, T.B.F.M.; ARENDS, J. In vivo remineralization of artificial subsurface lesions in human enamel. I. J. Biol. Buccale, v. 12, p. 49-57, 1984.

41. GIBBONS, R. The caries decline. A comment. Europ. J. oral Sci., v. 104, n. 4, Part II, p. 424-5, Aug. 1996.

42. GIBBS, M. et al. In vivo enamel fluoride uptake from and caries inhibition by topical fluoride agents. J. dent. Res., v. 60, n. 4, p. 770-5, Apr. 1981.

43. GIBSON, G.B.; RICHARDSON, A.S. Sticky fissure management: 30-month report. J. Canad. dent Ass., v. 46, n. 4, p. 255-8, Apr. 1980.

44. GILLINGS, B.; BUONOCORE, M. Thickness of enamel at the base of pits and fissures in human molars and bicuspids. J. dent. Res., v. 40, n. 1, p. 119-33, Jan./Feb. 1961.

45. GOEPFERD, S.J.; OLBERDING, P. The effect of sealing white spot lesions on lesions progression in vitro. Pediat. Dent., v. 11, n. 1, p. 14-16, Jan. 1989.

46. HELFENSTEIN, U. ; STEINER, M. Fluoride varnishes (Duraphat): a metaanalysis. Community Dent. oral Epidem., v. 22, p. 1-5, 1994.

47. HEUSER, H.; SCHMIDT, H.F.M. Deep impregnation of dental enamel with a fluorine lacquer for prophylaxis of dental caries. Stoma, v. 21, p. 91-100, 1968.

48. HICKS, M.J.; FLAITZ, C.M. Caries-like lesion formation around fluoride-releasing sealant and glass ionomer. Amer. J. Dent., v. 5, n. 6, p. 323-34, Dec. 1992.

49. Caries formation in vitro around a fluoride-releasing pit and fissure sealant in primary teeth. J. Dent. Child., v. 65, n. 9, p. 161-68, May/June, 1998. 
50. HICKS, M.J.; FLAITZ, C.M. Occlusal caries formation in vitro: comparison of resin-modified glass ionomer with fluoride-releasing sealant. J. clin. Pediat. Dent., v. 24, n. 4, p. 309-14, Summer 2000.

51. HICKS, M.J.; SILVERSTONE, L.M. Fissure sealants and dental enamel, a histological study of microleakage in vitro. Pediat. Dent., v. 16, n. 5, p. 353-60, Sept./Oct. 1982.

52. HICKS, M.J.; FLAITZ, C.M.; GARCIA-GODOY, F. Fluoride-releasing sealant and caries-like lesion formation in vitro. J. clin Pediat. Dent., v. 24, n. 3, p. 215-9, Spring 2000.

53. HIHARA, T.; NISHINO, M. Effects of diamine silver fluoride on arrestment and prevention of caries in primary tooth. Dent. Jap., v. 31, p. 93-95, Dec. 1994.

54. HOLM, G. B. et al. The caries-preventive effect of a fluoride varnish in the fissures of the first permanent molar. Acta Odont. Scand., v. 42, p. 193-7, 1984.

55. HOLMEN, L.; THYLSTRUP, A.; ARTUN, J. Clinical and histological features observed during arrestment of active enamel carious lesions in vivo (with 1 color plate). Caries Res., v. 21, p. 546-554, 1987.

56. HOLMEN, L. et al. A polarized light and scanning electron microscope study of the effect of Duraphat treatment on in vivo caries. Scand. J. dent. Res., v. 94, n. 6, p. 521-9, Dec. 1986.

57. HOROWITZ, A.M. Dental sealants in the prevention of tooth decay. National Institutes of Health Consensus Development Conference. J. Dent. Educ., p. 1-131, Jan. 1984. Supplement.

58. HUANG, G.F. et al. Synergistic effect of Nd:YAG laser combined with fluoride varnish on inhibition of caries formation in dental pits and fissures in vitro. $\mathbf{J}$. Formos. Med. Ass., v. 100, n. 3, p. 181-5, Mar. 2001.

59. IGARASHI, S. Bacteriological study on diamine silver fluoride $\left[\mathrm{Ag}\left(\mathrm{NH}_{3}\right)_{2} \mathrm{~F}\right]$ : changes of the proportional distribution of $S$. mutans in dental plaque by topical application of $\mathrm{Ag}\left(\mathrm{NH}_{3}\right)_{2} \mathrm{~F}$ and its antibacterial effect. Jap. J. Pedod., v. 16, n. 1, p. 1-18, 1978.

60. JENSEN, M.E. et al. Effects of a fluoride-releasing fissure sealant on artificial enamel caries. Amer. J. Dent., v. 3, p. 75-8, 1990.

61. JOHNSON, L.M. et al. Examination of a resin-modified glass-ionomer material as a pit and fissure sealant. Quintessence Int., v. 26, n. 12, p. 879-83, 1995.

62. KING, N. M. et al. Caries susceptibility of permanent first and second molars in children aged 5-15 years. Community dent oral Epidem., v. 8, p. 151-8, 1980. 
63. $\mathrm{KOCH}, \mathrm{G}$.; PETERSSON, L.G. Fluoride content of enamel surface treated with a varnish containing sodium fluoride. Odont. Revy, v. 23, p. 437-46, 1972.

64. KOCH, G.; HAKEBERG, M.; PETERSSON, L.G. Fluoride uptake on dry versus water-saliva wetted human enamel surfaces in vitro after topical application of a varnish (Duraphat @) containing fluoride. Swed. Dent. J., v. 12, n. 6, p. 221-5, Dec. 1988.

65. KOLEHMAINEN, L.; ATTILA, A.; KEININEN, J. Fluoride content of surface enamel treated with fluoride-containing varnishes and an amine $F$ solution as measured with a sensitive physical method. Proc. Finn. Dent. Soc., v. 74, p. 109-12, 1978.

66. KRAMER, P. F.; FELDENS, C. A . ; ROMANO, A. R. Promoção de saúde bucal em Odontopediatria: diagnóstico, prevenção e tratamento da cárie oclusal. São Paulo, Artes Médicas, 1997. 144 p.

67. LUSSI, A. Validity of diagnostic treatment decisions of fissure caries. Caries Res., v. 25, n. 4, p. 296-303, July/ Aug. 1991.

68. MALTZ, M.; CARVALHO, J. Diagnóstico da doença cárie. In: KRIGER, L. et al. ABOPREV. Promoção de Saúde Bucal. São Paulo, Artes Médicas, 1997. p. 71-91.

69. MEDEIROS, U.V.; BRUM, S.C. A proteção do esmalte por substâncias fluoretadas e os desafios cariogênicos. Rev. Ass. paul. Cirurg. Dent., v. 52, n. 6, p. 454-9, nov./dez. 1998.

70. MEDEIROS, U.V.; MENDONÇA, L.V.D. Formação "in situ" de fluoreto de cálcio a partir da utilização de vernizes fluoretados. Rev. bras. Odont., v. 54, n. 2, p. 102-6, mar./abr. 1997.

71. MELLBERG, J.R. Evaluation of topical fluoride preparations. J. dent. Res., v. 69 , p. 771-9, Feb. 1990. Special issue.

72. MERTZ-FAIRHURST, E.J. et al. A comparative clinical study of two pit and fissure sealants: 7-year results in Augusta, GA. J. Amer. dent. Ass., v. 109, n. 8, p. 252-55, Aug. 1984.

73. MÖLLER, H.; SCHRÖDER, U. Early natural subsurface caries. A SEM study of the enamel surface before and after remineralization. Caries Res., v. 20, p. 97-102, 1986.

74. MONICO, M.; TOSTES, M. Avaliação da penetração e infiltração do FUJI IX em sulcos e fissuras de terceiros molares. Estudo in vitro. In: REUNIÃO ANUAL DA SOCIEDADE DE PESQUISAS ODONTOLÓGICAS, 15., 1998, Águas de São Pedro. Anais... São Paulo, SBPqO, 1998. p. 12. 
75. MONTANDON, E.M.; SPERANÇA, P.A. Estudo comparativo in vitro da atividade antimicrobiana de agentes cariostáticos àbase de diamino fluoreto de prata. J. bras. odontoped. Odonto Bebe, v. 3, n. 16, p. 465-74, nov./dez. 2000.

76. MOORE, B.K. et al. Laboratory testing of ligth-cured glass ionomers as pit and fissure sealants. Gen. Dent., v. 43, n. 2, p. 176-80, Mar./Apr. 1995.

77. MOUNT, G.J. Glass-ionomer cements: past, present and future. Oper. Dent., v. 19, p. 82-90, 1994.

78. MURRAY, J.J.; RUGG-GUNN, A.J. Fluorides in caries prevention. Wright, PSG, 1976. p. 1-30.

79. NAGANO, T. The form of pit and fissure and the primary lesion of caries. Dent. Abst., v. 6, p. 426, 1961.

80. NAVARRO, M.F. de L.; PASCOTTO, R.C. Cimentos de ionômero de vidro. Aplicações clínicas em Odontologia. São Paulo, Artes Médicas, 1998. 179 p. (Série EAP-APCD, 2).

81. NEWBRUN, E. Cariology. 2. ed. Baltimore, Williams \& Wilkins, 1983. p. 50114.

82. NIKIFORUK, G. Understanding dental caries, I. Etiology and mechanisms. New York, Karger, 1985. p. 1-52.

83. NISHINO, M. Studies on the topical application of ammoniacal silver fluoride for the arrestment of dental caries. J. Osaka Univ. Dent. Sch., v. 14, p. 1-14, 1969.

84. NISHINO, M.; MASSLER, M. Imunization of caries susceptible pits and fissures with a diammine silver fluoride solution. Jap. J. Pedod., v. 2, n. 1, p. 16-25, 1977.

85. OKAMOTO, M.; MONOMURA, E.; SOBUE, S. Scanning electron microscopic studies on intact enamel surface after topical application of diamine silver fluoride. Jap. J. Pedod., v. 13, n. 1, p. 78-84, 1975.

86. ÖVREBÖ, R.C.; RAADAL, M. Microleakage in fissures sealed with resin or glass ionomer cement. Scand. J. dent. Res., v. 98, n. 1, p. 66-9, Feb. 1990.

87. PARFITT,G. The speed of development of the carious cavity. Brit. dent. J., v. 100, n. 8, p. 204-7, Apr. 17, 1956.

88. PIMENTA, L.A.F. Cárie secundária ao redor de restaurações de amálgama. Bauru, 1991. 107 p. Dissertação (Mestrado) - Faculdade de Odontologia de Bauru, Universidade de São Paulo. 
89. PIMENTA, M.C.F.; PAVARINI, A.; TÁRZIA, O. Assessment of fluoride-ion release through the Fluroshield sealant. J. dent. Res., v. 10, n. 4, p. 639, Apr. 1991. Special issue.

90. PIMENTA, M.C.F.; TÁRZIA, O.; PAVARINI, A. Assessment of the resistance to acid etching of human teeth proximal surface following of the removal of "Fluroshield-sealant" and "Prismashield-sealant". J. dent. Res., v. 71, n. 4, p. 967, Apr. 1992. Special issue.

91. PINTO, V.G. Brasil 97: Qual a nossa realidade epidemiológica? J. Ass. bras. Odont. Prev., v. 3, p. 3, maio/jun. 1997.

92. PRIMOSCH, R.E. A report on the efficacy of fluoride varnishes in dental caries prevention. J. clin. Prevent. Dent., v. 7, n. 6, p. 12-22, Dec. 1985.

93. RETIEF, D.H. et al. In vitro fluoride uptake, distribution and retention by human enamel after 1- and 24-hour application of various topical fluoride agents. J. dent. Res., v. 59, n. 3, p. 573-82, Mar. 1980.

94. Enamel fluoride uptake, distribution and retention from topical fluoride agents. Caries Res., v. 17, n. 1, p. 44-51, Jan./Feb. 1983.

95. ROCHA, C. et al. Diaminofluoreto de prata: uma opção em odontopediatria. J. bras. odontoped. Odonto Bebe, v. 2, n. 8, p. 296-301, 1999.

96. RODRIGUES, C.R.M.D. et al. Cariostático - Diaminofluoreto de prata. Rev. Ass. paul. Cirurg. Dent., v. 43, n. 4, p. 171-4, 1989.

97. RODRIGUES, O. et al. Saforide diaminofluoreto de prata e a sua aplicação clínica. Rev. Odont. Met., v. 5, n. 1, p. 27-35, 1984.

98. SANT'ANNA, G.R. de. et al. Cariologia. Diagnóstico, controle e tratamento. São Paulo, Santos, 2001. 82 p. (Série Caderno de Odontopediatria).

99. SARDI, M.P.S. et al. Avaliação da retenção e penetração de um selante à base de ionômero de vidro em fóssulas e fissuras oclusais. In: REUNIÃO ANUAL DA SOCIEDADE DE PESQUISAS ODONTOLÓGICAS, 12., Águas de São Pedro, 1995. Anais... São Paulo, SBPqO, 1995. p. 68.

100. SEPPÄ, L. Effects of a sodium fluoride solution and a varnish with different fluoride concentrations on enamel remineralization in vitro. Scand. J. dent. Res., v. 96, n. 4, p. 304-9, July/Aug. 1988.

101. . Efficacy and safety of fluoride varnishes. Compend. Contin. Educ. Dent., v. 20, Spec Iss, p. 18-26, 1999.

102. SEPPÄ, L.; FORSS, H. Resistance of occlusal fissures to demineralization after loss of glass ionomer sealants in vitro. Pediat. Dent., v. 13, n. 1, p. 39-42, Jan./Feb.,1991. 
103. SEPPÄ, L.; LUOMA, H. Fluoride content and calcium release from enamel, in relation to rat caries following the application of fluoride varnishes. Caries Res., v. 17, p. 258-63, 1983.

104. SEPPÄ, L.; FORSS, H.; SORMUNEN, P. Prevention of rat fissure caries by sodium fluoride varnish (Duraphat $\AA$ ) with different fluoride concentrations. Caries Res., v. 23, n. 5, p. 365-67, Sept./Oct. 1989.

105. SEPPÄ, L. et al. Prevention of fissure caries in rats by dietary F supplement with and without topical application of $\mathrm{F}$ and $\mathrm{Sr}+\mathrm{F}$. Caries Res., v. 22, p. 353-56, 1988.

106. SIEGEL, S. Estatística não-paramétrica (para ciências do comportamento). São Paulo, McGraw-Hill, 1975. 350 p.

107. SIQUEIRA, J.F.; SPERANÇA, P.A. Análise comparativa da atividade antimicrobiana de agentes cariostáticos: estudo in vitro. Recife, Universitária, 1997.

108. SKÖLD, L. et al. Four-year study of caries inhibition of intensive Duraphat application in 11-15-year-old children. Community Dent. oral Epidem., v. 22, p. 8-12, 1994.

109. SMALES, R.J.; GAO, W.; HO, F.T. In vitro evaluation of sealing pits and fissures with newer glass-ionomer cements developed for the ART technique. J. clin. Pediat. Dent., v. 21, n. 4, p. 321-3, 1997.

110. SONGPAISAN, Y. et al. Effects of glass ionomer cement, resin-based pit and fissure sealant and HF applications on occlusal caries in a developing country field trial. Community Dent. oral Epidem., v. 23, p. 25-9, 1995.

111. SORVARI, R. et al. Effect of fluoride varnish and solution on enamel erosion in vitro. Caries Res., v. 28, n. 4, p. 227-32, 1994

112. SOUSA NETTO, O.B.; ALMEIDA, I.C.S.; CURY, J.A. Avaliação do potencial remineralizante do diaminofluoreto de prata a 30\%. In: REUNIÃO ANUAL DA SOCIEDADE DE PESQUISAS ODONTOLÓGICAS, 16., Águas de São Pedro, 1999. Anais... São Paulo, SBPqO, 1999. p. 28.

113. SOUZA, I.P.R. Aquisição de fluoreto pelo esmalte humano, in vitro, após aplicação de dois agentes tópicos. Rio de Janeiro, 1992. Tese (Doutorado) - Faculdade de Odontologia, Universidade Federal do Rio de Janeiro.

114. SUZUKI, T. et al. Effects of $\mathrm{Ag}\left(\mathrm{NH}_{3}\right)_{2} \mathrm{~F}$ on plaque formation. J. dent. Res., v. 55, p. 174, 1976a. Special issue.

115. SUZUKI, T. et al. Mechanism of antiplaque action of diammine silver fluoride. J.

Osaka Univ. Dent. Sch., v. 16, p. 87-95, 1976b. 
116. TANTBIROJN, D.; DOUGLAS, W.H.; VERSLUIS, A. Inhibitive effect of a resinmodified glass-ionomer cement on remote enamel artificial caries. Caries Res., v. 31, n. 4, p. 275-80, July/Aug. 1997.

117. TAYLOR, C.L.; GWINNETT, A.J. A study of the penetration of sealants into pits and fissures. J. Amer. dent. Ass., v. 87, n. 6, p. 1181-8, Nov. 1973.

118. THYLSTRUP, A. et al. Promoting changes in clinical practice. Treatment time and outcome studies in a Danish public child dental health clinic. Community Dent. oral Epidem., v. 25, p. 126-34, 1997.

119. TOSTES AMARAL, M. A.;. Efeito de um cimento de ionômero de vidro sobre a remineralização de cárie na superfície oclusal: estudo in situ. São Paulo, 1999. 119 p. Tese (Doutorado) - Faculdade de Odontologia, Universidade de São Paulo.

120. TSUTSUMI, N. Studies on topical application of $\mathrm{Ag}\left(\mathrm{NH}_{3}\right)_{2} \mathrm{~F}$ for the control of interproximal caries in human primary molars. 1. Effect of $\mathrm{Ag}\left(\mathrm{NH}_{3}\right)_{2} \mathrm{~F}$ on both intact and artificially produced "white spot" enamel. Jap. J. Pedod., v. 19, n. 3, p. 522, 1981a.

121.

Studies on topical application of $\mathrm{Ag}\left(\mathrm{NH}_{3}\right)_{2} \mathrm{~F}$ for the control of interproximal caries in humam primary molars. 2. Effect of $\mathrm{Ag}\left(\mathrm{NH}_{3}\right)_{2} \mathrm{~F}$ on Streptococcus mutans on interproximal plaque. Jap. J. Pedod., v. 19, n. 3, p. 523-36, $1981 \mathrm{~b}$.

122. VAN DORP, C. S. E.; TEN CATE, J. M. Preventive measures and caries progression: an in vitro study on fissures and smooth surfaces of human molars. J. Dent. Child., v. 59, n. 4, p. 257-62, July/Aug. 1992.

123. VAN HERPEN, B.B.J.M.; ARENDS, J. Mineral distribution in enamel after in vivo de- and remineralization. J. Biol. Buccale, v. 15, p. 199-204, 1987.

124. VELASCO, L.F.L.; NÖR, J.E.; FIGUEIREDO, M.C. Microscopic evaluation of the penetration into pit and fissures of two glass ionomers used as sealants. J. dent. Res., v. 75, p. 70, 1996. Special issue.

125. WANG, C.W. et al. In situ remineralization of enamel lesions using continuous versus intermittent fluoride application. Caries Res., v. 27, p. 455-460, 1993.

126. WENDT, L.K.; KOCH, G. Fissure sealant in permanent first molars after 10 years. Swed. dent. J., v. 12, p. 181-5, 1988.

127. WEYNE, S.C. A construção do paradigma de promoção de saúde - um desafio para as novas gerações. In: KRIGER, L. et al. ABOPREV. Promoção de saúde bucal. São Paulo, Artes Médicas, 1987. p. 3-26.

128. WILSON, A.D.; KENT, B.E. The glass-ionomer cement: a new translucent dental filling material. J. Appl. Chem. Biotechnol., v. 21, p. 313, 1971. 
129. YAMAGA, R. et al. Diamine silver fluoride and its clinical application. J. Osaka Univ. Dent. Sch., v. 12, p. 1-20, 1972.

130. YANOVER, L. Fluoride varnishes as cariostatic agents: a review. J. Canad. dent. Ass., v. 6, p. 401-4, 1982.

131. YIP, H.K. The assessment of the fluoride uptake and release from resinmodified glass-ionomer restorative materials and fissure sealants. J. dent. Res., v. 75, p. 180, 1996. Special issue.

132. ZIMMERMAN, R.F.; RAWLS, H.R.; BASSETT, R.G. Fluoride release and physical properties of an experimental resin-filled sealant. J. dent. Res., v. 53, p. 295, 1984. Special issue. 
ABSTRACT 


\section{ABSTRACT}

The aim of this research was to evaluate, in vitro, with polarized light microscopy (PLM), the cariostatic potential of resin sealants and glass-ionomer cements, diamine silver fluoride solution and fluoride varnish applied on occlusal surface of human permanent molars. In order to achieve this goal, 70 caries free third human molars, extracted for clinical reasons, were randomly divided into seven groups $(N=10)$ : Gl - control (no sealing treatment); Gll - resin sealant without fluoride Delton ${ }^{\circledR}$; GIII - fluoride-releasing sealant Fluroshield $\circledast$; GIV - glass-ionomer cement Ketac Molar $\AA ;$; GV - resin-modified glass-ionomer cement Vitremer ${ }^{\circledR}$; GVI - 30\% diamine silver fluoride solution (DSF) Safluoride ${ }^{\circledR}$; GVII - 2,26\% fluoride varnish Duraflur ${ }^{\circledR}$. After dental prophylaxis with sodium bicarbonate, the materials were applied on the occusal surface, according to the manufacturer's instructions, and all tooth surfaces were covered with acid-resistant varnish except for the fissures and $1 \mathrm{~mm}$ rim of exposed enamel surrounding this area. The specimens were then exposed to 14-day de-remineralization cycles. After this period, they were sectioned, grounded, polished and imbibed in water for 36 hours, then examined with PLM and photographed. The depth $(\mu \mathrm{m})$ of the artificial caries lesions was assessed from the photomicrographs by measuring traverses running perpendicular to the enamel surface at six standardized points, whereas the area $\left(\mu \mathrm{m}^{2}\right)$ was measured using a reticulated device. Data were analyzed using Kruskal-Wallis and Dunn's multiple comparison tests at $5 \%$ of significance $(p<0,05)$. It was observed a statistically significant difference $(P=0.000000372)$ in lesion depht $(H=50,5)$ with lower values for GVII $(0,29 \mu \mathrm{m})$, GVI $(0,61 \mu \mathrm{m})$ and GV $0,89 \mu \mathrm{m})$ when compared to GIV $(3,69 \mu \mathrm{m})$, GII $(3,67 \mu \mathrm{m})$ and GIII $(2,10 \mu \mathrm{m})$, which differences were not statistically significant in relation to $\mathrm{Gl}$ $(5,81 \mu \mathrm{m})$. Considering the lesion area, there was a statistically significant difference $(P=0.0000256 ; H=51,3)$, with lower values for GV $\left(0,81 \mu m^{2}\right)$, GVII $\left(1,78 \mu m^{2}\right)$, GVI $\left(2,86 \mu \mathrm{m}^{2}\right)$, GIV $\left(3,69 \mu \mathrm{m}^{2}\right)$ and GIII $\left(4,91 \mu \mathrm{m}^{2}\right)$, when compared to Gll $\left(16,39 \mu \mathrm{m}^{2}\right)$ and GI $\left(24,04 \mu \mathrm{m}^{2}\right)$, which differences were not statistically significant. It was concluded that, fluoridated materials are effective in controlling the initiation and/or progression of caries lesion on the occlusal surface when compared to resin sealant without fluoride and no treatment. 
APÊNDICES 


\section{APÊNDICE A}

Quadro 1 - Média e desvio-padrão dos dados de profundidade da lesão (ì m) para os 7 grupos estudados.

\begin{tabular}{|c|c|c|c|c|c|c|c|}
\hline Amostra & GI & G II & G III & G IV & $G \mathrm{~V}$ & G VI & G VII \\
\hline 1 & - & 5,217 & 1,341 & $0,000^{*}$ & $0,000^{*}$ & 0,800 & $0,000^{\star}$ \\
\hline 2 & 3,275 & - & & $0,000^{*}$ & - & 0,748 & $0,000^{*}$ \\
\hline 3 & 6,079 & - & 3,028 & 4,910 & 1,391 & 1,305 & - \\
\hline 4 & 5,434 & 2,931 & 2,434 & 4,906 & - & $0,000^{*}$ & $0,000^{*}$ \\
\hline 5 & 7,736 & - & & 7,075 & 1,728 & $0,000^{*}$ & 0,986 \\
\hline 6 & - & 2,463 & & 2,402 & $0,000^{*}$ & $0,000^{*}$ & 0,955 \\
\hline 7 & 9,432 & 3,915 & 3,651 & 5,953 & - & 1,148 & $0,000^{*}$ \\
\hline 8 & 4,651 & 2,724 & - & $0,000^{*}$ & 0,695 & 0,635 & $0,000^{*}$ \\
\hline 9 & - & - & $0,000^{*}$ & $0,000^{*}$ & 2,573 & $0,000^{*}$ & $0,000^{*}$ \\
\hline 10 & 3,186 & 4,703 & $0,000^{*}$ & 2,634 & 2,385 & $0,000^{*}$ & 0,605 \\
\hline 11 & 4,985 & - & - & $0,000^{*}$ & - & $0,000^{*}$ & $0,000^{*}$ \\
\hline 12 & 3,970 & 3,072 & 1,826 & - & $0,000^{*}$ & 0,400 & 0,867 \\
\hline 13 & - & - & 2,619 & 9,641 & 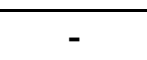 & 1,045 & $0,000^{*}$ \\
\hline 14 & 5,390 & 2,782 & & - & $0,000^{*}$ & 0,515 & $0,000^{*}$ \\
\hline 15 & - & - & - & 11,055 & - & 0,576 & $0,000^{*}$ \\
\hline 16 & - & 5,493 & 1,912 & 3,132 & 1,925 & 2,600 & 1,006 \\
\hline 17 & - & 4,835 & 3,472 & - & $0,000^{*}$ & - & - \\
\hline 18 & 5,217 & - & & - & - & - & - \\
\hline 19 & - & 2,275 & 2,869 & - & $0,000^{*}$ & - & - \\
\hline 20 & 10,436 & - & - & - & - & - & - \\
\hline Média total & 5,81 & 3,67 & 2,10 & 3,69 & 0,89 & 0,61 & 0,29 \\
\hline Desvio-padrão & 2,29 & 1,19 & 1,25 & 3,72 & 1,03 & 0,69 & 0,44 \\
\hline
\end{tabular}

* $=$ Ausência de lesão

- = Amostra excluída 
Quadro 2 - Média e desvio-padrão dos dados de área da lesão (ì m² ${ }^{2}$ para os 7 grupos estudados.

\begin{tabular}{|c|c|c|c|c|c|c|c|}
\hline Amostra & G I & G II & G III & GIV & G V & G VI & G VII \\
\hline 1 & 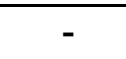 & 1,25 & 4,00 & $0,00^{*}$ & $0,00^{*}$ & 9,64 & $0,00^{*}$ \\
\hline 2 & 8,29 & - & - & $0,00^{*}$ & - & 12,25 & $0,00^{*}$ \\
\hline 3 & 32,72 & - & 6,79 & 4,88 & 0,64 & 3,13 & - \\
\hline 4 & 23,04 & 29,42 & 0,80 & 7,07 & - & $0,00^{*}$ & $0,00^{*}$ \\
\hline 5 & 36,00 & - & - & 2,40 & 1,85 & $0,00^{*}$ & 1,74 \\
\hline 6 & - & 16,00 & - & 5,95 & $0,00^{*}$ & $0,00^{*}$ & 1,74 \\
\hline 7 & 36,21 & 16,73 & 4,00 & 3,13 & - & 0,35 & $0,00^{*}$ \\
\hline 8 & 27,04 & 19,36 & - & $0,00^{*}$ & 0,64 & 3,13 & $0,00^{*}$ \\
\hline 9 & - & - & $0,00^{*}$ & $0,00^{*}$ & 2,70 & $0,00^{*}$ & $0,00^{*}$ \\
\hline 10 & 17,82 & 2,87 & $0,00^{*}$ & 4,88 & 1,37 & $0,00^{*}$ & 0,77 \\
\hline 11 & 33,17 & - & - & $0,00^{*}$ & - & $0,00^{*}$ & $0,00^{*}$ \\
\hline 12 & 20,53 & 16,00 & 2,56 & - & $0,00^{*}$ & 3,13 & 19,71 \\
\hline 13 & - & - & 5,72 & 2,62 & - & 4,90 & $0,00^{*}$ \\
\hline 14 & 16,00 & 13,92 & - & - & $0,00^{*}$ & 0,77 & $0,00^{*}$ \\
\hline 15 & - & - & - & 9,64 & - & 1,37 & $0,00^{*}$ \\
\hline 16 & - & 24,61 & 12,96 & 11,05 & 2,53 & 7,07 & 2,75 \\
\hline 17 & - & 19,57 & 5,83 & - & $0,00^{*}$ & - & - \\
\hline 18 & 15,43 & - & - & - & - & - & - \\
\hline 19 & - & 20,58 & 11,35 & - & $0,00^{*}$ & - & - \\
\hline 20 & 34,27 & - & - & - & - & - & - \\
\hline Média total & 25,04 & 16,39 & 4,91 & 3,69 & 0,81 & 2,86 & 1,78 \\
\hline $\begin{array}{l}\text { Desvio- } \\
\text { padrão }\end{array}$ & 9,49 & 8,32 & 4,28 & 3,72 & 1,04 & 3,81 & 5,04 \\
\hline
\end{tabular}

* = Ausência de lesão

- = Amostra excluída 


\section{APÊNDICE B}

Quadro 3 - Resultados da Prova de Kruskal-Wallis para profundidade da lesão.

\begin{tabular}{|c|c|c|c|c|}
\hline Grupo & g.L. & Mediana & $\mathbf{2 5 \%}$ & $\mathbf{7 5 \%}$ \\
\hline I & 6 & 5.30 & 4.31 & 6.908 \\
\hline II & 6 & 3.07 & 2.74 & 4.802 \\
\hline III & 6 & 2.43 & 1.46 & 2.988 \\
\hline $\mathrm{V}$ & 6 & 2.88 & 0.00 & 5.953 \\
\hline $\mathrm{VI}$ & 6 & 0.35 & 0.00 & 1.827 \\
\hline $\mathrm{VII}$ & 6 & 0.55 & 0.00 & 0.923 \\
\hline
\end{tabular}

$\mathrm{H}=50,5$ com 6 graus de liberdade $(\mathrm{P}=0.000000372)$

Quadro 4 - Resultados da Prova de Kruskal-Wallis para área da lesão.

\begin{tabular}{|c|c|c|c|c|}
\hline Grupo & g.L. & Mediana & $\mathbf{2 5 \%}$ & $\mathbf{7 5 \%}$ \\
\hline I & 6 & 25.04 & 16.91 & 33.72 \\
\hline II & 6 & 16.73 & 14.44 & 20.33 \\
\hline III & 6 & 4.00 & 1.24 & 6.55 \\
\hline V & 6 & 2.88 & 0.00 & 5.95 \\
\hline VI & 6 & 0.32 & 0.00 & 1.61 \\
\hline VII & 6 & 1.07 & 0.00 & 4.02 \\
\hline
\end{tabular}

$\mathrm{H}=51,3$ com 6 graus de liberdade $(\mathrm{P}=0.0000256)$ 


\section{APÊNDICE C}

Quadro 5 - Resultados do Teste de Comparações Múltiplas de Dunn a 5\% para comparar tratamentos dentro do fator Profundidade.

\begin{tabular}{|c|c|c|c|}
\hline Comparação & Diferença & $p$ & $\mathbf{Q}$ \\
\hline GI x GVII & $56.47^{\star}$ & 7 & 5.612 \\
\hline $\mathrm{Gl} \times \mathrm{GVI}$ & $49.46^{*}$ & 6 & 4.985 \\
\hline $\mathrm{Gl} \times \mathrm{GV}$ & $47.88^{*}$ & 5 & 4.513 \\
\hline Gl x Glll & 29.30 & 4 & 2.701 \\
\hline Gl x GIV & 25.21 & 3 & 2.466 \\
\hline GI x Gll & 12.16 & 2 & 1.121 \\
\hline Gll x GVII & $44.31^{*}$ & 6 & 4.296 \\
\hline Gll x GVI & $37.30^{*}$ & 5 & 3.665 \\
\hline Gll x GV & $35.71^{*}$ & 4 & 3.293 \\
\hline Gll x Glll & 17.14 & 3 & 1.547 \\
\hline Gll $\times$ GIV & 13.05 & 2 & 1.246 \\
\hline GIV x GVII & 31.27 & 5 & 3.238 \\
\hline GIV x GVI & $24.25^{*}$ & 4 & 2.550 \\
\hline GIV $\times$ GV & $22.67^{*}$ & 3 & 2.218 \\
\hline GIV x GIII & 4.09 & 2 & 0.391 \\
\hline Gll $\times$ GVII & $27.18^{*}$ & 4 & 2.635 \\
\hline GllI x GVI & $20.16^{*}$ & 3 & 1.981 \\
\hline Glll x GV & $18.58^{*}$ & 2 & 1.713 \\
\hline GV $\times G V I I$ & 8.60 & 3 & 0.855 \\
\hline $\mathrm{GV} \times \mathrm{GVI}$ & 1.58 & 2 & 0.160 \\
\hline GVI x GVII & 7.02 & 2 & 0.751 \\
\hline
\end{tabular}

= diferença significativa 
Quadro 6 - Resultados do Teste de Comparações Múltiplas de Dunn a 5\% para comparar tratamentos dentro do fator Área.

\begin{tabular}{|c|c|c|c|}
\hline Comparação & Diferença & $\mathbf{p}$ & $\mathbf{Q}$ \\
\hline GI x GVII & $55.78^{*}$ & 7 & 5.544 \\
\hline $\mathrm{Gl} \times \mathrm{GV}$ & $55.04^{*}$ & 6 & 5.189 \\
\hline $\mathrm{GI} \times \mathrm{GVI}$ & $44.47^{*}$ & 5 & 4.482 \\
\hline Gl x GIV & $40.43^{*}$ & 4 & 3.955 \\
\hline Gl $\times$ GIII & $33.39^{*}$ & 3 & 3.078 \\
\hline Gl x Gll & 10.11 & 2 & 0.932 \\
\hline Gll x GVII & $45.67^{\star}$ & 6 & 4.428 \\
\hline Gll $\times \mathrm{GV}$ & $44.93^{*}$ & 5 & 4.143 \\
\hline Gll $\times$ GVI & $34.35^{*}$ & 4 & 3.376 \\
\hline Gll $\times$ GIV & $30.31^{*}$ & 3 & 2.896 \\
\hline GII x GIII & $23.27^{\star}$ & 2 & 2.101 \\
\hline GIII x GVII & 22.40 & 5 & 2.172 \\
\hline GIII $\times$ GV & 21.65 & 4 & 1.997 \\
\hline GIII x GVI & 11.08 & 3 & 1.089 \\
\hline Glll $\times$ GIV & 7.04 & 2 & 0.673 \\
\hline GIV x GVII & 15.35 & 4 & 1.590 \\
\hline GIV x GV & 14.61 & 3 & 1.423 \\
\hline GIV $\times G V I$ & 4.04 & 2 & 0.425 \\
\hline GVI x GVII & 11.31 & 3 & 1.212 \\
\hline $\mathrm{GVI} \times \mathrm{GV}$ & 10.57 & 2 & 1.066 \\
\hline GV x GVII & 0.74 & 2 & 0.074 \\
\hline
\end{tabular}

= diferença significativa 